\title{
A geomagnetic polarity timescale for the Carboniferous
}

Mark W. Hounslow ${ }^{1}$

Lancaster Environment Centre, Lancaster University., Lancaster, UK, LA1 4YW and

School of Environmental Sciences, 4 Brownlow Street, Liverpool University, Liverpool, UK, L69 3GP

mark.w.hounslow@gmail.com

\begin{abstract}
The geomagnetic polarity pattern for the Carboniferous is incompletely known, but with the best resolved parts in the Serpukhovian and Bashkirian. Hence, data from both igneous and sedimentary units are also used in an additional polarity bias evaluation. In the Tournaisian to mid Visean interval polarity is mainly derived from palaeopole-type palaeomagnetic studies, allowing identification of polarity bias chrons. Seven polarity bias chrons exist in the Mississippian (MI $1 n_{B}$ to $M I 4 n_{B}$ ) with an additional 33 conventional magnetochrons and submagnetochrons (MI4r to MI9r). The Moscovian and Gzhelian polarity is best resolved in magnetostratigraphic studies from the Donets Basin and the southern Urals. Dispute about the reliability of these data is ill-founded, since an assessment of supporting data from palaeopole-type studies suggests that these datasets currently provide the best magnetic polarity data through the Pennsylvanian. Polarity bias assessment indicates a normal polarity bias zone in the Kasimovian. In the Pennsylvanian there are 27 conventional magnetochrons and submagnetochrons (PE1n to $\mathrm{Cl} 1 \mathrm{r}$ ) and one normal polarity bias chron ( $\mathrm{PE} 8 \mathrm{n}_{\mathrm{B}}$ ). The Kiaman Superchron begins in the mid Bashkirian, with clear data indicating brief normal polarity submagnetochrons within the Superchron. The magnetochron timescale is calibrated using $31 \mathrm{U}-\mathrm{Pb}$ zircon dates and a quantitative Bayesian-based age-scaling procedure.
\end{abstract}

\section{Introduction}

Stratigraphic changes in geomagnetic polarity (magnetostratigraphy) have been realized as having great utility in the Mesozoic and Cenozoic for global and local correlation and dating. These fossilised polarity changes are recorded as normal polarity states (geomagnetic field like today) and reverse polarity (magnetic poles opposite), with brief (100-1000's years) transitional field intervals between these two states. This bipolar state of the earths magnetic field has been predominant for the last $2 \mathrm{Ga}$ (Evans, 2006). The between-polarity transitional state has so far not been observed in Carboniferous rocks. Since the palaeomagnetic technique is largely independent of sedimentary or climatic environments; in the longer term it also has the ability for correlating chronostratigraphic and biostratigraphic boundaries into differing faunal realms. Its ability for solving dating and correlation problems in the Carboniferous has not yet shown fruit, but it has been realized in the Cenozoic (and to some extent the Mesozoic), where the technique can greatly surpass biostratigraphic methods in terms of chronostratigraphic resolution (Langereis et al. 2010; Miller \& Wright 2016).

However, in much of the Palaeozoic, especially so the Carboniferous and Devonian, the magnetic polarity pattern is insufficiently known in detail. This is primarily due to two factors, firstly many Palaeozoic sediments are very weakly magnetic (low remanence intensity), so it was not until the 1990's From Lucas, Schneider et al. (eds) The Carboniferous Timescale, Spec. Publ. Geol. Soc. Lond. 
that magnetometers were available that could reliably measure most sediments during demagnetization procedures (magnetic 'cleaning' or the 'washing' of Cox \& Doell 1960). Secondly, many Carboniferous successions are rather thermally mature (conodont alteration indices $>2$ to 3 ), having been buried to substantial depths, and in many cases the Fe-Ti oxides, which carry the remanence, have been subjected to substantial diagenetic modification (Johnson et al. 1995, 1997). Units may also be remineralized in various ways, both modifications potentially generating new magnetic minerals and destroying most of the originally deposited Fe-Ti oxides. This has contributed to the problem of perceived widespread remagnetisations (Van der Voo \& Torsvik 2012). These factors have created slow and difficult progress, in obtaining good Carboniferous palaeomagnetic data, since many palaeomagnetists would rather focus on easier to solve problems, with a better chance of scientific return.

This work is the first comprehensive assessment of existing strands of knowledge about the geomagnetic polarity in the Carboniferous, utilizing a wide range of palaeomagnetic and magnetostratigraphic data. This work firstly examines the historical context of geomagnetic polarity investigations of the Carboniferous, explaining development of evolving palaeomagnetic paradigms, that have strongly fashioned the development and reliability of Carboniferous magnetostratigraphic and palaeomagnetic studies. Secondly it examines in detail Carboniferous palaeomagnetic palaeopoles-type datasets from extrusive and igneous rocks, which help to fill some of the data gaps in geomagnetic polarity knowledge. Thirdly, the details of existing Carboniferous magnetostratigraphic studies are examined, bringing in new stratigraphic and dating information where relevant. Lastly, these data are synthesized into a Carboniferous polarity timescale, with inbuilt uncertainty estimates. Since many of the magnetic dataset are biostratigraphically linked to regional substages, this requires relationships to international stages to be defined, which largely follows those proposed by Richards (2013), unless otherwise indicated.

\section{Progress in developing a Carboniferous polarity scale}

The development of palaeomagnetism, focused on the Carboniferous, has followed several phases which relate to the development of new kinds of instrumentation along with analytical methods and magnetisation paradigms. This development can be broadly classified into three phases: a) Early reconnaissance work in the 1950's and early 1960's; b) early use and development of demagnetization techniques in the 1960's to 1980 's; c) a remagnetisation 'realization' in which more complex magnetisation (and remagnetisation) models were being increasingly more widely utilized from the 1990 's to the present day.

Throughout this study interval, the bulk of palaeomagnetic studies in the Carboniferous have focused on palaeopoles-type studies which use palaeomagnetic directional data to assess continental or tectonic motions. This kind of data does not directly help with knowing the detailed stratigraphic changes in magnetic polarity (since sampling is not designed to do this), but it may help understanding if certain time intervals have a preferential bias to either reverse or normal polarity (Belshé 1957; Irving \& Pullaih 1976; Algeo 1996). A very much smaller subset of Carboniferous palaeomagnetic studies utilize a stratigraphically well-constrained samplings strategy, to allow an estimate of the pattern of polarity change with stratigraphy. Still fewer studies are true magnetostratigraphic studies in the sense of Opdyke \& Channel (1996). 


\section{Early reconnaissance work}

The 1950's saw the development of the founding principles of evaluating the fidelity of rocks as geomagnetic recorders, and means to describe the directional data (Irving 1959; Cox \& Doell 1960 for reviews). These early attempts were largely focused on defining possible continental motions and the characteristics of the ancient magnetic field. The first Carboniferous palaeomagnetic studies were on volcanics and sediments by Clegg et al. (1954) and Belshé (1957) from Britain, Australian volcanics and sedimentary rocks (Irving 1957; Irving \& Green 1958) and the Visean -Bashkirian Barnet Shale (Martinez \& Howell 1956; Howell \& Martinez 1957) and the late Pennsylvanian-Permian Naco Group sandstones (Runcorn 1956) from the USA. These had contributed to a substantial set of Carboniferous palaeomagnetic data by the late 1950's (Irving 1959), from which Everitt \& Belshé (1960) were able to infer that the early Carboniferous was an interval of both reverse and normal magnetic polarity and the late Carboniferous was predominantly reverse polarity. This significant inference was later amplified by work on Permian rocks from Australia by Irving \& Parry (1963), who extended this predominantly reverse polarity interval well into the Permian, and who coined the term for this late Carboniferous mid Permian reverse polarity interval, as the Kiaman magnetic interval (here referred to as the Kiaman Superchron, Hounslow \& Balabanov 2018). From 1959 Khramov and co-workers began their study of the Carboniferous sediments of the Moscow and Donets Basins (Khramov, 1963; Khramov et al. 1974).

These early studies did not use alternating field (AF) or thermal demagnetization (which all studies now use), to isolate the primary remanence since these methods were only beginning to be developed in the late 1950's, for AF 'cleaning', firstly using static AF fields (Brynjólfsson 1957; Creer 1958; As \& Zijderveld 1958), and later tumbling of samples in AF (Creer 1959) with subsequent improvements (McElhinny 1966). In spite of this initial inadequacy, both polarities were present in Carboniferous rocks (Irving 1957; Belshe 1957; Clegg et al 1957, Howell \& Martinez 1957). However, additional magnetizations from the present day and after the time of rock formation (secondary magnetizations; Creer 1957; Irving 1959; Collinson \& Runcorn 1960; Irving et al. 1961) contaminated these early datasets, sometimes giving smeared directions along a great circle, called by Khramov (1958) the 'circle of remagnetisation'. Some studies tried to use long term storage of samples in near zero magnetic field to attempt removal of the modern viscous components (Creer 1957 1959; Akimoto \& Kushiro 1960), which contaminated the primary components. This was a process much used later by early Russian workers, and termed 'temporal demagnetisation'. By the end of the 1950's Irving (1959) had concluded that the "reconnaissance stage of palaeomagnetism" had come to an end, and that more detailed studies focusing on single stratigraphic units was needed. At this time the Carboniferous could be magnetically divided into the Kiaman and pre-Kiaman magnetic polarity intervals with the stratigraphic position of this boundary thought to be in the Westphalian (late Bashkirian) or near the base of the Stephanian (Moscovian) (Irving \& Parry 1963).

\section{Early studies using demagnetization techniques}

The first attempt in the Carboniferous to express the future vision of Irving (1959) was the study of Wilson \& Everitt (1963) on the Kinghorn lavas from Fife in Scotland. This is the first true magnetostratigraphic study in the Carboniferous, since it related sampling to a detailed stratigraphic succession (see later). This was also ground breaking in several other ways, firstly that it used thermal demagnetisation to isolate the primary Carboniferous remanence using a magnetometer and furnace that the Imperial College team (and others; Stacey 1959, Irving et al. 1961) had been working on for some years (Wilson 1960). Thermal demagnetization had preliminary use in the 1950's mostly for rock-

From Lucas, Schneider et al. (eds) The Carboniferous Timescale, Spec. Publ. Geol. Soc. Lond. 
magnetic or geomagnetic palaeointensity work, with Doell (1956), Cox (1957) and Akimoto \& Kushiro (1960) applying this to directional data in Cenozoic volcanics and sediments. Secondly, the PhD of Wilson (1960) extensively used "vector heating diagrams" (a method later published in Wilson 1961) to display the directional and intensity data (what are now widely referred to as 'Zijderveld plots' following Symons \& Stupavsky 1974; Dunlop 1979), a key method of displaying demagnetization data. Similar plots also appeared at the same time in the thesis of Everdingen (1960) (cited in Dietzel 1960) based at Utrecht. This was very significant, since Wilson's vector heating diagrams clearly showed isolation of the primary components during demagnetization, and also the directional information of the secondary components, in the straight lines on his diagrams. Much of what Wilson discussed in using these diagrams is explained in more detail in Dunlop (1979) now widely used as standard by all palaeomagnetists. As explained by Storevedt (2016) these and other developments opened up a new era for palaeomagnetic research in which magnetisation paradigms moved from 'simple' to a more "realistic experimental-analytical approach".

During these early studies on Carboniferous volcanic successions by Wilson and co-workers, Russian workers studied Carboniferous sediments from 1959 to the 1970's from the Moscow and Donets basins, and sections adjacent to the Sea of Azov (Khramov 1967; Khramov et al. 1974). These largely used the methods that had existed in the west in the 1950's, but they refined the 'temporal'-demagnetisation methods with imposition of opposed components to correct for the modern viscous field components (Khramov et al. 1974: Khramov 1987). Carboniferous sediments studied were largely fined-grained clastics, with sometimes a focus on red-beds, which previous Carboniferous studies (Belshé 1957) has shown to give best results. In spite of adherence to the 1950's paradigms these Russian dataset appear to display what looked like some sensible directional changes and datasets, with cross-section validation of magnetozones, tied to a detailed bio- and lithostratigraphy (Fig. 1). These and other datasets appeared in the Carboniferous part of the magnetostratigraphic time scale of Khramov \& Rodionov (1980) and what has become known as the 'general magnetostratigraphic scale' (Guizikiv 2016). This had many later revisions, with the last major one being that of Khramov \& Shkatova (2000), along with some later 'time adjustments' used by Perchersky et al. (2010)(Fig. 2). Unfortunately all source details and stratigraphic relationships of how the Carboniferous part of the 'general magnetostratigraphic scale' was constructed were not published, so it is impossible to critique and re-evaluate details, so this scale is not used in this compilation, which instead uses primary sources.

Some of the sample sets presented in these early Russian Carboniferous studies have been re-examined using modern demagnetisation techniques (Iosifidi et al. 2010, 2016, 2018; losifidi \& Mikhailova 2017). For example in the Bashkirian data shown in Fig. 1, losifidi et al. (2016) re-examined a sample set covering $35 \mathrm{~m}$ in the $\mathrm{C}_{2}{ }^{2}$ interval (Cheremshankian, mid Bashkirian), which show very similar mean directions to the same interval studied in the 1960s (Iosifidi et al. 2016). However, these newer studies have shown an absence of Carboniferous normal polarity samples in the previously available sample sets (losifidi et al. 2016), except in the Aleksinian substage (mid Visean, early Warnantian).

Unfortunately these new studies do not seem to have assessed the normal polarity intervals (although this is not entirely clear) or evaluated how the earlier studies of the same sample sets might have arrived at the interpreted normal polarity like shown in Fig. 1. The key issues may have been oversimple magnetisation models, Permian remagnetisations, with perhaps dual polarity Permian-Triassic remagnetisations, such as in the Priksha River sections (Iosifidi et al. 2018) which is in the Tulian substage (mid Visean; Richards 2013). The extent to which these explanations might apply to the From Lucas, Schneider et al. (eds) The Carboniferous Timescale, Spec. Publ. Geol. Soc. Lond. 
normal polarity intervals in the Pennsylvanian as shown in Fig. 1 is unknown. Other data is assessed here to try and evaluate the reality of these Pennsylvanian normal magnetozones.

\section{The remagnetisation 'realisation'and a new magnetisation paradigm}

A widening realization of the problem of Kiaman reverse polarity remagnetisations on Carboniferous (and other) successions evolved in the 1970s and 1980's as more studies on late Palaeozoic successions were performed. This followed initial studies implicating wide-scale remagnetisations, found first in the Devonian (Chamaluan and Creer 1964; Chamaluan 1964), a phenomena that was not only restricted to sediments (Storevedt 1970). Clearer understanding of the characteristics of remagnetisations evolved in the late 1980's, when the impact of this was realized on magnetizations previously interpreted as Devonian- Carboniferous in age (McCabe \& Elmore 1989; Van Der Voo \& Torsvik 2012). The simple (two-component) magnetization models of the 1950's and early 1960's had evolved to an appreciation of the observational and interpretational complexity of palaeomagnetic data (Roy \& Lapointe 1978, Storevedt 2016), which often come with 3-4 magnetisation components in pre-Permian datasets.

During this interval of 'realization' Tarling and Turner in Britain had a program of studies looking specifically to determine geomagnetic polarity and magnetization processes in Carboniferous sediments (Turner \& Tarling 1975, Turner 1975, Perry 1979, Turner et al. 1979, Addison 1982, Addison et al. 1985, Palmer 1987). Although there were indications in some sections of probable dual polarity (Turner et al. 1979), the magnetizations where either largely Kiaman remagnetisations (McCabe \& Channel 1994), or mixtures with what would now be considered as probably primary Carboniferous directions (Morris 1971; Turner et al. 1979), but were not considered so at the time. Palmer et al. (1985) attempted to provide a summary of existing Carboniferous polarity information (largely from paleopole-type studies), but failed to try and incorporate the distinction between Kiaman remagnetisations and potentially primary Carboniferous polarity datasets. In a sense these largely carbonate-based studies were utilizing the palaeomagnetic paradigms of the 1950's (e.g. stability indices) which was also reflected in the Carboniferous Russian datasets of the time, rather than the 'post-realization paradigms' expressed in holistic data assessments like that proposed by Roy \& Lapointe (1978).

A turning point for the re-evaluation of the Carboniferous magnetic polarity stratigraphy was the assessment of Roy \& Morris (1983), which excluded most remagnetized data from the North America Carboniferous datasets, and identified the base of the Kiaman Superchron around the NamurianWestphalian boundary (mid Bashkirian), largely based on the data from the Maritime Provinces of eastern Canada (Roy \& Park 1969, 1974). The later key contributions from Neil Opdyke and co-workers followed, starting with the first magnetostratigraphic studies on N. American Carboniferous sediments by DiVenere \& Opdyke (1990, 1991a, 1991b) using the post-realisation paradigms of Roy \& Lapointe (1978). These events set the scene for later reviews of Carboniferous magnetostratigraphy by Idnurm et al. (1996), Opdyke (1995) and Opdyke \& Channell (1996). The magnetostratigraphic studies from the 1990 's onwards form the backbone of what is described in the following sections.

\section{Geomagnetic polarity bias during the Carboniferous}

The sample collection strategy of most palaeopoles-type studies (i.e. those used for palaeotectonic studies), do not usually provide sufficient information to describe the stratigraphic relationships between the individual sampling sites. Rather sites tend to be grouped into members, formations or

From Lucas, Schneider et al. (eds) The Carboniferous Timescale, Spec. Publ. Geol. Soc. Lond. 
particular rock units, with a focus on those most likely to yield good results (often igneous units or red beds in the Carboniferous). Nevertheless, it is possible to utilize data from palaeopoles-type studies to construct an assessment of polarity bias (dominance of a particular polarity) during the Carboniferous like Irving \& Pullaiah (1976) and Algeo (1996) has attempted for the Palaeozoic, and Irving \& Parry (1963) and Palmer et al. (1985) had previously attempted for the Carboniferous. Similar approaches have been used in the Ordovician and Silurian to help define reverse and normal polarity dominance in parts of the Ordovician and Silurian respectively (Trench et al. 1993). Palaeopole-type sampling is in contrast to magnetostratigraphic studies, in which the stratigraphic relationship between samples is of paramount importance.

Since magnetostratigraphic data do not exist for the entire Carboniferous, the following assessment utilizes polarity bias data from Carboniferous igneous and sedimentary rocks. The first part uses data from extrusive and intrusive igneous rocks, weaving this data onto studies where stratigraphic-style sampling has been undertaken in these units. The following part examines the magnetostratigraphic data from sedimentary rocks, and integrates this with the polarity bias data from sediments. Many of the relevant palaeomagnetic and magnetostratigraphic studies in the Carboniferous have inadequate documentation of stratigraphic and biostratigraphic relationships, so these are dealt with in some detail, to allow a more holistic, integrative magnetostratigraphic evaluation, in the final sections.

\section{Polarity data from extrusive and intrusive rocks}

Data collation utilized the palaeomagnetic database v4.6b (McElhinney \& Lock 1976), the MagIC database (Tauxe et al. 2016), and all available Carboniferous (and earliest Permian) published up to early 2020. These palaeopole datasets were filtered to exclude:

a) Data with large age uncertainties (either radioisotopic or stratigraphic). Large here is often greater than a stage age uncertainty.

b) Data in which the original published material could not be examined, or was not sufficiently detailed to explain the data quality. This eliminated some early palaeomagnetic studies, prior to the development of competent demagnetization schemes. It also eliminated many of the Russian 'pole lists' contained in the above databases.

c) A re-evaluation of stratigraphic and radioisotopic dates was also undertaken to revise the ages of sampled units, since their original publication. 29 of the 50 have revaluated for ages.

The selected igneous and volcanic data are listed in Table 1, along with the percentage of reverse polarity in the studies, the age information and age confidence interval of the sampled sites (Fig. 3). Separated from the list in Table 1 (and not in Fig. 3) are some of the palaeomagnetic studies on the Tamworth Belt of the New England Orogen in eastern Australia. These complement and add to the magnetostratigraphic study of Opdyke et al. (2000) where sampling has been undertaken with a strong stratigraphic context built-in. These Australian studies are dealt with in a separate section below. An integration of the magnetic polarity data of Wilson \& Everitt (1963) and Piper et al. (1991) from British late Visean volcanic units is also dealt with separately below, since these have rather better stratigraphic control than most studies, and can be stratigraphically linked together.

\section{Global Polarity Bias data}

The igneous rock bias data clearly show the reverse polarity dominance of the Pennsylvanian (i.e. in the Kiaman Superchron), beginning ca. $320 \mathrm{Ma}$, a bias to rather more reverse polarity dominance during the

From Lucas, Schneider et al. (eds) The Carboniferous Timescale, Spec. Publ. Geol. Soc. Lond. 
Serpukhovian and Visean, and a normal polarity bias in the Tournaisian through early Visean (Fig. 3). Younger than $320 \mathrm{Ma}$ in the Pennsylvanian, several studies have some normal polarity data indicating possible brief normal polarity intervals embedded in a dominance of reverse polarity.

The palaeomagnetic study of Halvorsen et al. (1989) from the Karkonasze granite and its metamorphic aureole, sampled the gray porphyritic granite and andalusite - condierite hornfels of the micaceous schist country rock. The granite has an extensive range of dating methods applied, both SHRIMP, Rb-Sr and CA-ID-TIMS, suggesting a formation age at $312 \mathrm{Ma}$ (Kryza et al. 2014), with emplacement and crystallization within less than 1 Myr duration. Both sample sets show evidence of dual polarity, although the hornfels has some contamination from a steeper ( $B$ component) magnetization. The directional data were consistent with other associated granites of mostly reverse polarity, and have a combined palaeopole $3^{\circ}$ from the spline-fit pole at $310 \mathrm{Ma}$ of Torsvik et al. (2012), all indicating the well constrained nature of this dataset. This may represent one of the normal polarity intervals in the DB4n or DB5n composite of Khramov et al. (1974) shown in Fig. 1.

The data of Beck et al. (1991) is from an extensive ( $900 \mathrm{~km}$ long) late Paleozoic granitic plutonic belt sampled at Lago Ranco and Lago Rinihue (S. Chile), which ranged in composition from biotite granodiorite to pyroxene-bearing diorite. Their data indicate only one site (on south side of Lago Ranco) has normal magnetic polarity (8 samples) with all others from Lago Ranco reverse polarity. This site has a K/Ar date on biotite of $309 \pm 8 \mathrm{Ma}$ (Beck et al. 1991). Deckart et al. (2014) dated a biotite-amphibole granodiorite (from Principal Cordillera) from the southern shore of Lago Ranco (FO09-38) yielding a SHRIMP U-Pb (Temora standard) age of 305.9 $\pm 2.4 \mathrm{Ma}$, which is similar to a range of other dates from the late Carboniferous Chilean plutons with a mean 309 Ma. Although the directional dataset is a little sparse, and the details of intrusions around the normal polarity site are not supplied, it does suggest this normal polarity event may be younger in age to that in the Karkonasze granite

The study of the Malaoba Formation volcanics by Yi et al. (2015) from the Tacheng Basin (NW China) found one possibly normal polarity site (a rhyolite, 9 samples) among 12 other sites (basalts, rhyolites and tuffs) of reverse polarity. An Ar/Ar date from the top of the succession yielded an age of $304 \pm 4.7$ $\mathrm{Ma}$. The authors did not use the data from this site (declination is displaced by $\sim 80^{\circ}$, but inclination is consistent), so it's not clear how reliable this single site is. If this is valid, it is possible it is the same normal polarity interval as found at Lago Ranco.

The undemagnetised samples of Clegg et al. (1957) and Everitt (1960) from the Shatterford sill in the English West Midlands, shows reasonably well defined dual polarity, and was originally dated as Westphalian, since its emplaced into Westphalian- C (Bolsovian, early Moscovian) clastics (Kirton 1984). This is one of number of other genetically-related intrusions in the same area which have been dated at around 295 -296 Ma using K/Ar (Fitch \& Miller 1964), probably providing only a minimum age (Bolsovian is now around 315-310 Ma; Aretz et al. 2020). Field evidence suggests the sills were intruded into waterlogged sediment, so may be nearly contemporaneous with the Bolsovian (Kirton 1984), so the normal polarity samples may be the same age as those of the Karkonasze granite.

Edel et al. (2014) has reported dual polarity late Carboniferous magnetisations (normal polarity C, and D ; reverse $C^{\prime}$ and $D^{\prime}$ components) from various intrusive bodies in Corsica and Sardinia. Assuming their late Carboniferous reconstructions for Corsica and Sardinia are correct, their site polarities would be From Lucas, Schneider et al. (eds) The Carboniferous Timescale, Spec. Publ. Geol. Soc. Lond. 
dominated by normal polarity magnetization (their $C$ and $D$ components). However, their data includes units such as the Isola Diorite and the Osani Andesite, which have well constrained crystallization ages at $300 \pm 6.1 \mathrm{Ma}$ and $308 \pm 3.0 \mathrm{Ma}$ respectively (Casini et al. 2012), yet are interpreted as exclusively normal polarity, using their tectonic reconstruction. The Edel et al. (2014) interpretation is that many of the late Carboniferous units acquired their magnetizations during the interval $311 \pm 10$ to $288 \pm 0.7 \mathrm{Ma}$, from a remagnetisation during the emplacement of the U2 magmatic episode. The dominance of normal polarity is erroneous, with respect to their ages and data here (and in Hounslow \& Balabanov 2018), and so the polarities originally inferred were not been used (Table 1; Fig. 3). However, if the $C$ and $\mathrm{D}$ component directions are reverse polarity and the magnetisation ages are close to the crystallisations ages, then these would be magnetisations acquired with Sardinia and Corsica in a similar rotational position to that in the Triassic, rather than $\sim 180^{\circ}$ rotated as suggested by Edel et al. (2014). Hence, the polarity has been inverted, giving a more sensible polarity distribution. The dual polarity Barrabisa granitoids (ca. 315.5 Ma; Table 1) fall within the Late Bashkirian- Moscovian interval (Fig. 3) possibly correspond to one of the normal polarity magnetozones in Fig. 1.

\section{New England Orogen, Tamorth Belt, E. Australia}

The palaeomagnetic studies in the forearc basin, that is the Tamworth Belt of the New England Orogen (Geeve et al. 2002; Klootwijk 2002 ,2003, 2016, 2019), provides a unique set of stratigraphically wellconstrained, sampling sites, which allow these to be combined with the more magnetostratigraphicstyle study of Opdyke et al. (2000) from the northern part of the Tamworth Belt. The Mississippian and Pennsylvanian successions in most of the Tamworth Belt are divided by a late Visean to Serpukhovian uplift and hiatus, with the Pennsylvanian successions seeing glaciogenic sediments deposited with volcanogenic and fluvial units (Glen \& Roberts 2012; Phillips et al. 2016). The palaeopoles-type studies have primarily sampled the numerous extrusive lavas and pyroclastic flows, except for that of Opdyke et al. (2000) which also sampled suitable clastic and volcaniclastic lithologies. These studies have covered a few sites from the Tournaisian, with rather more sites from the Visean, to the more extensive sampling by Opdyke et al. (2000) in the Early and Middle Pennsylvanian. The successions are divided into a number of northwest to southeast distributed fault and thrust bounded blocks, with each block having a rather different lithostratigraphy (Roberts et al. 1993, 1995, 2003a, 2006; Phillips et al. 2016). Age control on the partly marine Mississippian successions is a brachiopod zonation, age-calibrated against western European successions (Roberts et al. 1993), with some additional age calibration against conodonts and ammonoids (Jenkins et al. 1993), as well as SHRIMP dates (Roberts et al. 1995; Fielding et al. 2008). The Pennsylvanian units have a very low resolution biozonation, supported by some fossil plants (Roberts et al. 1993), supplemented with a large set of SHRIMP dates from volcanic units (Fielding et al. 2008; Roberts \& James 2010).

The Mississippian in the SE of the Tamworth belt in the Rouchel, Gresford and Myall blocks has the most extensive polarity dataset (Fig. 4), based on the work of Geeve et al. (2002) and Klootwijk (2016, 2019). This appears to show at minimum five normal polarity magnetozones (Fig. 4), labeled here TB (for Tamworth Belt). The detailed sampling of the Gilmore Volcanic Fm (Gresford Block) by Klootwiijk (2019) appears consistent with the data of Geeve et al. (2002) from the same unit, to define a rather more detailed pattern of polarity changes through this unit (Fig. 4).

In the NW Tamworth Belt, at the Rocky Creek syncline and Werrie syncline, the Mississippian units are the Caroda Fm and the Merlewood Fm respectively (Fig. 5). The Merlewood Fm in the Werrie Syncline 
has best age control in the Kydalyn Member, which has faunas from the Linoprotonia tenuirugosa Subzone of the Delepinea aspinosa Zone (Roberts \& James 2010; Fig. 5). The same brachiopod subzone is present in the limestone unit in the upper part of the Horton River section (Caroda post office bridge; Mory 1980). It seems likely that the normal polarity level Klootwijk (2002) found in the upper andesite level in the Merlewood Fm, is therefore that found in the Kooringal Dacite and unnamed ignimbrite at Horton River (Opdyke et al. 2000) and in the High Valley Tuff (Klootwijk 2002) at Moorabool (Fig. 5). This may be TB2n which is within the $D$. aspinosa Zone in the Isismurra Fm in the Rouchel Block (Fig. 4). The Barney Springs Andesite is present in the upper part of the Caroda Fm (Wang et al. 2001), and has similar trace element chemistry and polarity to the Kooringal Dacite (Roberts et al. 2003), suggesting likely equivalence. In addition, the similarity of the corrected (Black et al. 2003) SHRIMP date (339.5 $\pm 3.7 \mathrm{Ma}$ ) on the Barney Springs Andesite (Roberts et al. 2003a; Fig. 5) and the U-Pb date (342.8 \pm 2.7 $\mathrm{Ma}$ ) from ignimbrites in the Albano region above TB2n (Roberts et al. 2006; Klootwijk 2016; Rouchel Block; Fig. 4) indicates that all these levels may represent polarity magnetozone TB2n (Figs. 4,5 ).

Normal polarity site 71 of Opdyke et al. (2000) in the lower part of the Merlewood Fm (Werrie Syncline, right of Fig. 5) may therefore be magnetozone TB1n, which in the Rouchel Block is in the early Molinacian, Isismurra Fm (Fig. 4). The magnetozone correlations in Figs. 4 and 5 in the Visean, may be rather optimistic considering the sparse sampling and uncertainties in correlation and it is equally likely that the polarity pattern is more complex than suggested in Fig. 4. Anderson et al. (2003) also found normal polarity in the Mamberra Andesite Member of the Gilberton Fm (approx $335 \mathrm{Ma}( \pm 7)$, ASUD 2020) which appears to be Visean (Oversby \& Mackenzie 1994), and may be one of the TB3n- TB5n magnetozones, although this formation extends into the Famennian, based on the plant fossil Leptophloeum australe.

In the Pennsylvanian of the Rocky Creek Syncline region, from the northern part of the Tamworth Belt (Fig. 6), Opdyke et al. (2000) and Klootwijk (2002) define the base of the Kiaman Superchron, with the last assured normal polarity level at the Wanganui Andesite Member (Roberts et al. 2003a). This normal polarity magnetozone extends downwards through the underlying sandstones, but not necessarily to the base of the Clifden Fm (Fig. 6). Opdyke et al. (2000) also identified a normal polarity site 118, overlying the Peri Rhyolite Mbr (The Tops section, Rocky Creek; Fig. 6), but full confidence in its stratigraphic position was complicated by faulting. Klootwijk (2002) has two sites with normal polarity near the base of the Ermelo Pyroclastics (Fig. 6), also with overlying and underlying reverse polarity sites of Opdyke et al. (2000), indicating an additional normal magnetozone, which may be brief. These have been labeled TB6n and TB7n (Fig. 6). Overlying the Clifden Fm, the Rocky Creek Conglomerate and the Lark Hill Fm contain sites only of reverse polarity.

Anderson et al. (2003) have found normal polarity in the upper most site from the Routh dacite (SHRIMP $321.9 \pm 6.6 \mathrm{Ma}$ ) an age which overlaps the TB7n magnetozone in the Clifden Fm (corrected date of $322.4 \pm 2.8 \mathrm{Ma}$ ) which may represent the same normal magnetozone. In these Pennsylvanian successions additional regional correlation levels are provided by the glacial intervals of Fielding et al. (2008) with the C1 glacial in the Spion Kop Conglomerate inferred by them to be in the early Namurian (Serpukhovian), and the C3 glacial in the Eulowie Pyroclastics Member and upper most Rocky Creek Conglomerate (Fig. 6), inferred to be in the early Moscovian (Fielding et al. 2008).

In the Werrie syncline of the central Tamworth Belt, Opdyke et al. (2000) and Klootwijk (2003) found From Lucas, Schneider et al. (eds) The Carboniferous Timescale, Spec. Publ. Geol. Soc. Lond. 
only reverse polarity in the Currabubula Fm (Fig. 7). These datasets overlap in corrected SHRIMP age ( $316 \mathrm{Ma}$ ) with the data from the upper part of the successions in the Rocky Creek Syncline to the north (Figs. 6, 7). The corrected SHRIMP dates from the Currabubula Fm suggest the C3 glacial is around 316 Ma (Fig. 6), and in the Eulowie Pyroclastics and upper Rocky Creek Conglomerate, somewhat similar between 314-317 Ma, confirming the reverse-only polarity in the upper part of the Rocky Creek Conglomerate.

\section{Volcanics from the British late Visean}

The study of Piper et al. (1991) has provided one of the better age-constrained studies on lavas (and intrusives) interbedded in late Asbian and early Brigantian limestones in Derbyshire. This study followed earlier pioneer studies on these rocks by Belshé (1957) and Everitt \& Belshé (1960), also finding both reverse and normal polarity. Piper et al. (1991) sampled lava's at differing stratigraphic levels over some $30 \mathrm{~km}$ in a limestone platform succession in the upper part of the Bee Low Limestone Fm and the Monsal Dale Limestone Fm (Fig. 8). These lavas were generated at a number of separate volcanic centres probably at separate events in time. Due to an absence of a detailed section-based biochronology, the relative age relationships of the lavas across this area are not entirely secure, being based largely on lithostratigraphy from bore-hole records (Walters \& Ineson 1981). The biochronology for the limestones comes from a mixture of coral biozones, supplemented by ammonoids, foraminifera and some conodonts, mostly at the formation level (rather than section based).

The Bee Low limestone Fm contains the late Asbian coral biozone G of Mitchell (1989). Foraminifera assemblages from this formation in the Eyam Borehole (Strank 1985) indicate a mid to late Asbian age for the Bee Low Limestone, with the volcanic-bearing upper part of the formation around the AsbianBrigantian boundary (i.e. somewhat lower than the lithostratigraphic boundary; Fig. 8). Ammonoid fauna from the Bee Low limestone Fm indicate the G. globostriatus subzone (B2b Subzone; Waters et al. 2011) of the late Asbian. The brachiopod Davidsonina septosa which has been considered diagnostic of the late Asbian (although also known in the earliest Brigantian, Somerville \& Strank 1984) is found below the Lower Millers Dale Lava in the Cressbrooke Dale area (Fig. 8). In these units the AsbianBrigantian boundary is usually placed at the disconformity between the Bee Low and Monsal Dale limestones (Butcher \& Ford 1973; Walkden 1977; Gutteridge 1989), conforming to the Mississippian sequence 9 - 10 boundary (Herbig et al. 2016).

Coral-based biozones are most detailed in the Brigantian, with the Lower and Upper units of the Monsal Dale Limestone Fm corresponding to coral divisions $\mathrm{H}$ and I of Mitchell (1989), with the overlying coral biozone $\mathrm{J}$ missing or undetected. Divisions $\mathrm{H}$ and I correspond to the early part of the RC8 Belgium coral biozone (Poty et al. 2006). The overlying Eyam Limestone Fm is assigned to coral biozone K (Mitchell 1989; uppermost part of RC8 in Belgium). This agrees with the presence of the latest Visean to early Serpukhovian conodont Lochriea mononodosa (Smith et al. 2017) and an ammonoid $P_{2}$ subzone assemblages in the overlying Eyam Limestone Fm (George et al. 1976). The regional correlation of lavas within the Monsal Dale Limstone Fm is less secure above the basal part, since while correlation is possible in the central area using the Litton Tuff (Butcher \& Ford 1973) and Cressbrook Dale Lava (Waters et al. 2009) and the Upper Dale and Hobs House coral bands as guides (Fig. 8; Butcher \& Ford 1973), correlations south to the Lathkill Dale to Matlock area are less confident. Within the southern area, the Upper Matlock Lava is high in the Monsal Dale Limestone Fm, with the Conksbury Lava correlated to a level a little below the Upper Matlock Lava (Bridge \& Gozzard 1981, based on dark- 
coloured limestone intervals). Walters \& Ineson (1981, their Fig. 8) correlated the Conksbury Lava with an ash level, below the Upper Matlock Lava, based on its relationship to the Orionastrae placenta band in the Wince No1 borehole.

The relative correlation of the Shacklow Wood area to the Lathkill Dale area is the least well defined, with Bridge \& Gozzard (1981) correlating the Litton Tuff to the Conkbury Lava, although the relative position based on formation thickness of these units in the Monsal Dale Fm, more likely indicates a lower level closer to the Lathkill Dale Lava for the Litton Tuff correlation (Fig. 8). This suggests the Upper Matlock Lava and the Shacklow Wood Lava represent different normal polarity intervals (Fig. 8). Walters \& Ineson (1981) similarly correlate the Shacklow Wood Lava to a level below the Lathkill Shell bed, and probably also below the Lathkill Dale Lava. For reasons not explained, Piper et al. (1991) placed both the Shacklow Wood and Lee Bottom lavas between the Lower Matlock and Winster Moor lavas, which seems erroneous. Immediately below the Lathkill Lodge Lava in the Haddon Fields borehole is the 'Brigantian' coral Diphyphyllum lateseptatum (Sommerville \& Strank 1984) which Aitkinhead et al. (1985) assumed to indicate the Asbian-Brigantian boundary interval (Fig. 8), although this inference contradicts the previous proposed relationships ( $D$. lateseptatum first appears in the $R C 7 / \beta$ coral biozone in Belgium, in the later part of sequence 9; Poty et al., 2006; 2014). These proposed correlations give three normal polarity intervals, all within the early Brigantian (Fig. 8). Alternatively, foraminiferal data from the Eyam Borehole (Strank 1985) suggests the Asbian-Brigantian boundary may be in the Chee Rock Mbr around the level of the two lower reverse polarity lava's in the CastletonBradwell Moor area (Fig. 8).

Everitt and Belshé (1960), Wilson (1960) and Wilson \& Everitt (1963) were the first significant studies to use thermal demagnetization procedures on Carboniferous volcanic rocks, working on the Kinghorn successions in Fife (Scotland) to isolate cleaned dual polarity directions. This followed preliminary undemagnetised data published on these same sample sets by Clegg et al. (1957), in which they identified a magnetic polarity boundary within the succession of lavas. Following Wilsons PhD work (Wilson 1960), partly on these units, Wilson and Everitt (1963) later synthesized their data on the succession of the Kinghorn Volcanic Fm, relating the detailed sampling by Everitt to the numbered stratigraphic log information in Geike (1900) to provide a detailed polarity record through part of the late Visean (Fig. 9). Torsvik et al. (1989) later measured some of the same lava's, but without the stratigraphic detail provided by the study of Wilson \& Everitt (1963). However later, Wilson (1966) revised his interpretation of the fidelity of the geomagnetic field recording at Kinghorn, finding a relationship between the quantified percentage of optically observable ilmenite and polarity (see the table in Fig. 9), inferring a (mineralogically-driven) self reversal mechanism instead (see discussion in McElhinney 1973). This relationship can clearly be seen, using the basaltic petrological classification of Allan(1923) shown in the data in Fig. 9. This relationship is due to an unfortunate sampling bias to normal polarity basalts with abundant augite-olivine phenocrysts in the lower part of the Kinghorn succession, mostly above the $80 \mathrm{~m}$ level (Fig. 9 ). At this time a fierce debate about the 'reality' of geomagnetic field reversals was raging (McElhinney 1973) due to a correlation in some studies (with dubious statistics; Merrill 1985) between igneous rock petrology and polarity (Wilson \& Watkins 1967). It was not until the late 1970's that evidence from baked contacts of igneous bodies was more widely accepted to prove the reality of field reversals (McElhinney \& McFadden 2000). The conclusions of Wilson (1966) undoubtedly clouded the great significance of the Kinghorn data. Remarkably, the pioneering work of Wilson and Everitt (1963) still stands 6 decades later as the best stratigraphically- constrained magnetic polarity study on From Lucas, Schneider et al. (eds) The Carboniferous Timescale, Spec. Publ. Geol. Soc. Lond. 
Carboniferous lavas.

The chronology of the lava succession has improved since these early palaeomagnetic studies. From Buntisland in the west to Kircaldy in the east, the lavas are easily-related to other successions in the Scottish Midland Valley, by a lithostratigraphy (Brown et al. 1999; Guirdham et al. 2003), linked to miospore zonations (Brindley \& Spinner 1989; Owens et al. 2005), and some foraminifera data from the upper part (Lower Limestone Fm) of the Kinghorn-Kirkcaldy succession (Karbub 1993; Cozar et al. 2008). Palynological correlation suggests the base of the Lower Limestone Fm (base of Hurlet Limestone) is equivalent to the base of the 1st Abden Limestone at Kinghorn (Brindley \& Spinner 1989).

The lowest part of the miospore Bellispores nitidus - Reticulatisporites carnosus (NC) Zone can be placed above the lava succession within the Second Abden Limestone (Fig. 9; Brindley \& Spinner 1989; Owens et al. 2005), which is the equivalent of the St Monance Little Limestone (Owens et al. 2005). In northern England and Scotland the base of this zone is within the late Brigantian (P2b-P2c ammonoid zones), with the underlying Tripartites vetustus-Rotaspora fracta (VF) zone extending into the late Asbian (McLean et al. 2018). The overlying Seafield Tower Lmst (equivalent of the Charlestown Main Limestone; Fig. 9) is of latest Brigantian age (ammonoid zone P2c; Wilson 1980; Owens et al. 2005) .

The Asbian-Brigantian boundary is not easily located in the succession at Kinghorn, although (Karbub 1993) suggested it was located between the $1^{\text {st }}$ and Second Abden limestones, but which is inconsistent with the data from Cozar et al. (2008) who indicated the base of the Lower Limestone Fm (Hurlet Limestone) was mid Brigantian. Unpublished foraminifera data (some from the same sections as Karbub 1993) of P. Cózar from the First and Second Abden Limestone, the St. Monans Little and St. Monans Brecciated limestones (of east Fife) indicates the Asbian-Brigantian boundary lies below the $1^{\text {st }} A b d e n$ Limestone (Pers. Comm. Pedro Cózar, 2020).

At Kinghorn the position of the base of the underlying VF miospore zone is less clear, but may possibly extend as low as the Houston Coal, thought to be above the Dunnet Shale at Kinghorn (Allan 1923, Francis 1961; Brindly \& Spinner 1989), although this is based on a correlation of this coal southwards (Francis 1961). In the section, the last VF biozone indicators are in the first Abden Limestone (Brindley \& Spinner 1989), with all underlying samples from the Raistrickia nigra-Triquitrites marginatus (NM) miospore zone. The Burdiehouse Limestone and its correlatives, are a well defined marker in this region (Guirdham 1998) in the lower part of the NM miospore zone (Rex \& Scott 1987), with the base of the NM biozone normally placed in the early Asbian (Owens et al. 2005). These data suggests the Kinghorn Volcanic Fm ranges from early Brigantian at the top, through the late Asbian, possibly extending into the mid Asbian. A K-Ar whole rock age of $338 \pm 4 \mathrm{Ma}$ from a roadside lava sample between Burntisland and Kinghorn (Fitch et al. 1970) indicates an early Holkerian- late Asbian age range, using the timescale of Richards (2013). Ar-Ar dates from the lavas have failed to yield sensible ages (Monaghan \& Browne, 2010).

At Kinghorn some later intrusive sills in the top part of the succession, need to be removed for magnetostratigraphic comparison, but do appear to extend the polarity data from the Derbyshire lavas down through the Asbian, with the reverse polarity in the upper $90 \mathrm{~m}$ of the Kinghorn Volcanic Fm probably equivalent to that seen in the late Asbian in Derbyshire (Figs. 8, 9). These two studies appear to jointly define a composite polarity from around the mid Asbian into the later parts of the early From Lucas, Schneider et al. (eds) The Carboniferous Timescale, Spec. Publ. Geol. Soc. Lond. 
Brigantian ( 332-335 Ma; Richards, 2013). The normal polarity in the mid to lower part of the Kinghorn Volcanic Formation may relate approximately to the level of the normal polarity Paterson Volcanics (magnetozone TB5n) in the Australian sections (Figs. 4, 9).

\section{North American magnetostratigraphic data}

The most comprehensive modern Carboniferous magnetostratigraphic studies are from the MinudieJoggins sections in Nova Scotia (DiVenere \& Opdyke 1991b), Maringouin Peninsula, New Brunswick (DiVenere \& Opdyke 1990), Cape Breton Island (Opdyke et al. 2014) and the Mauch Chunk Formation in Eastern Pennsylvania (DiVenere \& Opdyke 1991a). These sections are in fluviatile red-siltstones and sandstones in the Mauch Chunk Fm. In Nova Scotia and New Brunswick studies from predominantly red-sometimes grey coloured fluvial successions. Opdyke et al. (2014) attempted to integrate these magnetostratigraphic datasets, but for the Mauch Chunk Formation utilized a stratigraphic age analogue from Virginia, which was inappropriate to E. Pennsylvania. Hence, a revised age model for the Mauch Chunk Fm will be examined in detail, based around regional relationships, which are crucial in reconstructing a magnetostratigraphy in the late Mississippian.

\section{Magnetostratigraphy of the Mauch Chunk Fm}

The magnetostratigraphy from the Mauch Chunk Formation is based around four sections (Fig. 10) from a transect across the southern Anthracite Coal Field of eastern Pennsylvania (DiVenere \& Opdyke 1991a, Opdyke \& DiVenere 2004). Within Pennsylvania, the Mauch Chunk Fm displays lateral facies change from much thicker fluvial red-beds in the east to much thinner red beds, interbedded with a variety of marine carbonates and clastics to the SW (Fig. 11). Within the S. Anthracite Coal Field area the Mauch Chunk Fm has upper and lower divisions, transitional in facies to the underlying Pocono Fm (Mt Carbon Member) and overlying Pottsville Fm (Tumbling Run Mbr). Filmore et al. (2012) formalised three divisions of the Mauch Chunk Fm in the S. Coal Anchracite Fields, with the names Lavelle, Indian Run and Hometown members, corresponding to the similarly defined, unnamed previous divisions (Wood et al. 1969). The Mauch Chunk Fm boundaries are based on the lowest presence of red beds at the lower boundary, and highest presence of red beds at the upper boundary (Wood et al. 1969). In the Anthracite Fields area, the Hometown Mbr interdigitates northwards, with the Indian Run Mbr and with the Tumbling Run Mbr (of the Pottsville Fm) southwards (Wood et al. 1969; Fig. 11). Consequently Mauch Chunk member and formation boundaries are probably time-transgressive within $\mathrm{E}$. Pennsylvania. It is not entirely clear how the magnetostratigraphy in the south Lavelle section (Fig. 10) correlates to that in the Jim Thorpe section (Opdyke \& DiVenere 2004). Opdyke et al. (2014) used the higher (dotted) correlation in Fig. 10, but if the Lavelle Member is 180 m thick (Wood et al. 1969) and not too much is removed by faulting in the south Lavelle section, a correlation lower in the south Lavelle section is possible (solid correlation line in Fig. 10).

The only direct age dating of the Mauch Chunk Fm in the Anthracite Coal Fields area is based on the Adiantites antique macroflora from the upper part of the Indian Run Mbr (Fig. 10) at the Schuylkill Gap section (Jennings 1985). In Europe, A. antique occurs primarily in the Visean, but is also known from the early Namurian (ca. Serpukhovian). Vertebrate tracks from the Mauch Chunk Fm provide a similar, Mississippian age assignment, but based on poorer biochronological resolution (Filmore et al. 2012).

In the S. Anthracite Field area the Mauch Chunk Fm appears to display continues deposition from the underlying Pocono Fm to the overlying Pottsville Fm (Fig 11), these formations also provide bracketing

From Lucas, Schneider et al. (eds) The Carboniferous Timescale, Spec. Publ. Geol. Soc. Lond. 
age constraints. Plant fossils described by Read (1955) from the upper part of the Pocono Fm in the S. Coal Anthracite Fields (around Pottsville and Jim Thorp) where assigned to the 'Triphyllopteris' spp. Zone of Osagean age (Read \& Mamey 1964), now assigned to megafloral Zone 2 (Wagner 1984; Eble et al. 2009) of the late Tournaisian-early Visean.

The Pottsville Fm overlying the Mauch Chunk Fm has a complex regional distribution due to unconformities (Fig. 11), the most significant one of which, in the S. Anthracite Coal Field area, is within the upper part of the Pottsville Fm (Edmunds et al. 1999; Fig. 11). Megafloral Zones 4 and 5 (Read \& Mamey 1964) occur within the Tumbling Run Mbr. Read and Mamey's Zone 4 is within Lykens Valley No. 5 and No. 6 coals (around the mid part of the member), about $120 \mathrm{~m}$ above its base (Edwards et al. 1999) and would appear to indicate an early Langsettian (Westphalian A; Fig. 11; mid Bashkirian) or slightly older age (Eble et al. 2009). European substages are used here, since later this data will be related to Canadian Maritime successions, which also use these substages for division. Megafloral Zone 5 is within Lykens Valley No. 4 coal, and is in the upper part of the member ( $160 \mathrm{~m}$ above base of member) and is around mid Langsettian (Eble et al. 1999). These age constraints for the Mauch Chunk $\mathrm{Fm}$ in the S. Anthracite Coal Field suggest the magnetostratigraphy of DiVenere \& Opdyke (1991a) and Opdyke \& DiVenere (2004) may encompass, at maximum, an interval from the early Visean to the later mid Bashkirian (i.e. to the late 'Namurian'; Fig. 11).

Additional age constraints can also be attempted using longer-range correlation to W. Pennsylvannia and $\mathrm{N}$. Virginia, where marine units interdigitate with the Mauch Chunk Fm, and provide potentially correlative regressive and transgressive cycles with the Mauch Chunk Fm units in W. Pennsylvania (Brezinski 1989a). Uttley (1974) examined in detail the correlation of the Mauch Chunk Fm in SW Pennsylvanian to Ohio and correlated the Loyalhanna Limestone to the Ste. Genevieve Limestone in Ohio. The two units also have similar brachiopod assemblages (Kammer \& Lake 2001). Based on foraminifera and conodonts Maples and Waters (1987) placed the base of the Ste. Genevieve Limestone at the base of the Chesterian, which is equivalent to the base of $16 \mathrm{i}$ zone of Mamet and the base of foraminifera zone MFZ14 (Poty et al., 2006). Uttley (1974) correlated the Wymps Gap limestone (Fig. 11) to the Jonathan Creek Limestone of Scatterday (1963), the lower part of which contains conodonts from the Gnathodus bilineatus-Cavusgnathus charactus biozone, the $2^{\text {nd }}$ conodont zone of the Chesterian (Scatterday 1963; Repetski \& Stamm 2009). Based on conodonts, Horowitz \& Rexroad (1972) have also suggested a 'pre Glen Dean' age for the Wymps Gap Limestone. Trilobites from the Wymps Gap Limestone also place this unit in the early Chesterian (Brezinski 2009). Uttley (1974) correlated the Reynolds Limestone (Fig. 11) to the Glen Dean Fm, which is mid Chesterian in age (Kladognathus mehli condont zone, Al-Tawil et al. 2003; Repetski \& Stamm 2009). Kammer \& Spinger (2008) and others have suggested the same correlation.

Two possible options (long and a short duration Mauch Chunk options) have been proposed to correlate the SW. Pennsylvania marine units to the Mauch Chunk Fm in the Anthracite Coal Fields in E. Pennsylvania. Edmunds (1996) and Ettensohn (2009) placed the Loyalhanna Limestone in the mid part of the E. Pennsylvania Mauch Chunk Fm, whereas Berg et al. $(1983)$ and Brezinski $(1999,2009)$ place the Loyalhanna Limestone near the base (as shown in Fig. 11). In SW Pennsylvanian, N. Maryland and Ohio two major progradations of coarser clastics are represented by the units between the Loyalhanna and Wymps Gap limestones, and in the part of the Mauch Chunk Fm above the Greenbrier Fm (Uttley 1974; Brezinski 1989a, 1989b), generating two major westwards directed progradation pulses in the From Lucas, Schneider et al. (eds) The Carboniferous Timescale, Spec. Publ. Geol. Soc. Lond. 
Chesterian (Fig. 11). These may relate to the sequence $\mathrm{C} 5+\mathrm{C} 6$ lowstand and the sequence $\mathrm{C} 10+\mathrm{C} 11$ lowstands of Al-Tawil et al. (2003) from W. Virginia. Currently there is no similar sequence stratigraphy for the Mauch Chunk Fm from E. Pennsylvania, but it is possible that the lower of these westwardsdirected clastic progradations is represented by the sandstone dominated interval in the lower part of the Indian Run Mbr at Jim Thorpe (Fig. 10), and the upper progradation by the Hometown Member. Perhaps the three calcrete rich intervals (relatively wetter environment; Fig. 10) in the Indian Run Mbr may be the equivalent of the limestone units in SW Pennsylvania? This correlation option is compatible with the lower placement of the Loyalhanna Limestone, and suggests the Meramecian may be absent or condensed in the Lavelle Member or upper part of the Pocono Fm. This age option is broadly similar to that suggested by Opdyke et al. (2014) based on magnetostratigraphic correlation to the eastern Canadian sections.

For the long duration Mauch Chunk option, the sandstone dominated interval in the lower part of the Indian Run Mbr, may represent the upper clastic progradation in SW Pennsylvania, compatible with the mid- Mauch Chunk position of the Loyalhanna Limestone (i.e. not that shown in Fig. 11). Based on cyclostratigraphy, Kodama (2019) has proposed an accumulation rate of the Indian Run Member of 5.69 $\mathrm{cm} / \mathrm{Ka}$, which using the average Mauch Chunk Fm thickness estimates of Woods et al. (1969) would give a duration of $\sim 20 \mathrm{Ma}$ for the formation, compatible with the duration of the Chesterian plus Meramecian (Richards 2013). This cyclostratigraphic duration is compatible with Edmunds (1996) and Ettensohn (2009) for the mid-placement of the Loyalhanna Limestone Mbr, suggesting the magnetostratigraphy of the Mauch Chunk Fm may extend into the early Visean. Currently there is insufficient stratigraphic data internal to the N. Appalachian basin, to distinguish these two age options for the Mauch Chunk Fm.

\section{Magnetostratigraphy from New Brunswick and Nova Scotia}

Studies in the Cumberland Basin in New Brunswick and Nova Scotia, and on Cape Breton Island, have defined a composite magnetostratigraphy through the Brigantian to early Langsettian (latest Visean to mid Bashkirian) (DiVenere \& Opdyke 1990, 1991b; Opdyke et al. 2014; Fig. 12). The younger part of this interval is of strong significance, since it is around the base of the Kiaman Superchron, and key polarity marker in the Carboniferous. The age constraining biostratigraphy is largely provided by a miospore zonation, which links it to the British substages, since the two areas were in the same floral province (Utting et al. 2010). A major unconformity separates Mississippian from Pennsylvanian strata (Fig. 12). Whilst the palynostratigraphy has similarity to the European miospore zonations, it also has significant differences, which do not allow the British substage boundaries to be confidently located, but instead provid weaker age equivalence (Utting et al. 2010).

The Mississippian data provides good inter-section consistency, allowing a composite polarity to be constructed (re-labeled more simply from the composite in Opdyke et al. 2014; Fig. 12). Palynological data from the Middleborough Fm is lacking, and its assumed Brigantian age is based on the age for the underlying Lime-kiln Brook Fm (faunal division B of the Windsor Group; Jutras et al. 2016). The faunal division B has been dated as late Asbian (Giles 2008), but Mamet (1970) has assigned foraminifera Zone 15 to this division, which may be early Warnantian (approx. early to mid Asbian; Poty et al. 2006). Since the Lime-kiln Brook Fm is laterally transitional into the lower part of the Middleborough Fm (Jutras et al. 2015), it is possible the oldest part of the magnetostratigraphy (magnetozones NN1-NN2?) may extend into the Asbian rather than be entirely Brigantian. Sedimentological work suggests that the Shepody

From Lucas, Schneider et al. (eds) The Carboniferous Timescale, Spec. Publ. Geol. Soc. Lond. 
and Claremont formations (Claremont Fm = Enrage Fm in New Brunswick) are both bounded by hiatus of unknown duration (Jutras et al. 2015), so the magnetostratigraphy is possibly fragmented. The magnetozone NN7n may be somewhat thicker than indicated in the polarity composite (Fig. 12), since the correlation relationship between the Spring Valley \#1 core and other sections, which contain the Reticulatisporites carnosus Zone (such as in the Pomquet $\mathrm{Fm}$ ) are not constrained by zonal boundaries. Opdyke et al. (2014) correlated the reverse magnetozone in the upper part of the Enrage Fm in the Spring Valley \#1 core with the equivalent of NN5r, which seems unlikely, since NN5r magnetozone is within the older Grandispora spinosa-Ibrahimispores magnificus Zone in the Maringouin Peninsula and Minudie-Joggins sections (Fig. 12).

The Pennsylvanian age sections in the Port Hood Fm (in the Margaree Member) from Cape Breton Island preserve normal magnetozone NN8n overlain by a reverse polarity interval NN8r-NN9r (Fig. 12). Opdyke et al. (2014) suggested the base of the Boss Point Fm (at the Joggins section) related to this reverse polarity interval seen in the upper part of the Broad Cove Chapel section (similar to correlation shown in Fig. 12). However, the correlation of NN9n is not well constrained by miospores since all these units are within the Reticulatisporites saetosa Zone, and its possible NN9n (within the Chignecto Bay Mbr of the Boss Point Fm; Fig. 12) may fall above the section at Broad Cove Chapel. It is likely magnetozone NN8n is of ?Yeadonian age and so is probably the equivalent to magnetozone DB1n in the Lower Bashkirian in the Donets Basin (Fig. 1).

In the New Glasgow Fm from the eastern part of the Cumberland Basin, Buchan \& Chandler (1999) found nine out of 13 sites were normal polarity, with all located within the lower part of the distal member of this formation. The New Glasgow Fm overlies the Boss Point Fm, which is a mappable unit from west to east across the Cumberland Basin. The New Glasgow Formation has similar sedimentology to the Polly Brook Fm, the alluvial-fan, lateral equivalent of the better dated Langsettian age units from the western part of the Cumberland Basin (Allen et al. 2011). Palynology of the New Glasgow Fm indicates probable Langsettian age, but is presently poorly defined (Buchan and Chandler 1999; Allen et al. 2011.). The New Glasgow Fm also has a macroflora dominated by cordaitaleans with minor pteridosperms and ferns, similar to those from the Little River and Joggins formations (with reverse polarity; Fig. 12) from the SW Cumberland Basin (Falcon-Lang 2006). These relationships suggest an additional substantive normal magnetozones may exist above the reverse polarity Little River Fm, perhaps equivalent to magnetozone DB2 $n$ in the Donets Basin (Fig. 1), since a substantial thickness of Langsettian age strata overly the Little River Fm in the SW Cumberland Basin (Allen et al. 2011).

\section{Tengiz, Kazakhstan}

A magnetostratigraphy was determined by Ratcliffe et al. (2013) across the Mississippian-Pennsylvanian boundary using core from the Tengiz carbonate platform in Kazakhstan (Fig. 13). Their study utilised a range of sequence stratigraphic, trace element geochemisty and isotope geochemistry to constrain the correlations between a number of wells. The magnetostratigraphic datasets are from platform-top well T-220 and platform flank well T-5056 (Fig. 13). Existing correlation relationships on this platform have largely used down-hole log based data to construct a sequence stratigraphic model adapted over the whole platform (Collins et al. 2006; Kenter et al. 2006), tied to a large number of log-correlation tie points. In the data from the younger part of the carbonate platform studied by Ratcliffe et al. (2013) these surfaces are the Lvis13, Serp_SSB and Bash_SSB boundaries, which cover an interval from the late Visean to the late Bashkirian (Kenter et al. 2006; Fig. 13). Chemostratigraphic (trace element based) From Lucas, Schneider et al. (eds) The Carboniferous Timescale, Spec. Publ. Geol. Soc. Lond. 
divisions (Packages 1 to 6 , based on core and cuttings) allowed additional constraining relationships between wells to support these inter-well correlations shown in Fig. 13. Foraminifera data (Brenckle \& Milkina 2003) indicate a broad assignment of some parts of the cored intervals to the Russian substages (Figs. 13 and 14b). The sequence stratigraphic divisions also have a foraminiferal biostratigraphy (Brenckle \& Milkina 2003) linked to the traditional Russian substage/horizon divisions. This can in turn be linked to the sequence stratigraphic model (Weber et al. 2008) to allow a reasonably well-defined chronostratigraphic model for the boundaries (Kenter et al. 2006).

The 'Serp_SSB' sequence boundary links the two wells together, with normal polarity magnetozone TZ5 $n$ in both wells spanning this boundary, and underlying normal magnetozone TZ4n, and overlying normal magnetozone TZ6n also detected in both wells (Fig. 13). In addition, whole rock carbon isotope data linked to the chemostratigraphic packages, sequence stratigraphy and magnetostratigraphy in well T-220 allow refinements of the chronostratigraphy particularly in the Bashkirian (Fig. 14a). This suggests that the polarity succession in well T-220 probably starts around the base Serpukhovian (based on correlation to the Antler Basin record; Fig. 14a) and ends around the mid Bashkirian (later part of Akavasian substage), based on isotope correlations to the Askyn River section (Fig. 14a). The sequence boundary Serp_SSB is close to the Serpukhovian-Bashkirian boundary, clearly shown by the large negative $\delta^{13} C_{\text {carb }}$ excursion in the late Serpukhovian in the correlated sections (Fig. 14a). These correlations indicate the uppermost magnetozone TZ6n at Tengiz is mid Akavasian age (Fig. 14a).

\section{Synthesis of a polarity timescale}

\section{Mississippian}

To infer geomagnetic polarity in the Tournaisian- Visean (prior to the oldest parts of the magnetostratigraphic data from the Mauch Chunk Fm), there are data available from: 1 ) the rather widely spaced sampling from the Tamworth Belt in Australia (Fig. 4); 2) polarity bias data from palaeopole-type studies (Fig. 15). 3) The study of Liu et al. (1991) covering the Devonian-Carboniferous boundary, and 4) earliest Carboniferous data synthesized by Kolesov (2007) from NE Asian sections.

To add to the polarity bias data for igneous rocks (Table 1; Fig. 3) polarity bias data has been collated from sedimentary rocks (Table 2). This dataset started with the MagIC and palaeomagnetic databases, but filtered the data set to exclude; a) poorly dated studies, or studies with a wide chronostratigraphic range of sampling (ideally $<12 \mathrm{Ma}$ range), b) studies which had limited sampling, c) studies whose details could not be scrutinized, and d) suspected remagnetisations. The Serpukhovian- mid Bashkirian interval has adequate magnetostratigraphic data, so was excluded in this analysis (Fig. 15). A magnetozone that is based solely on polarity bias data, with widely spaced stratigraphic sampling, is given the subscript $B$ (i.e. bias magnetozone $M 1 r_{B}$, Fig. 15). This is the case for much of the Tournaisian to mid Visean interval. A bias magnetozone implies that it probably contains (as yet unknown), opposite polarity sub-magnetozones and so this designation also expresses the type of data that contribute to the final polarity timescale.

The study by Liu et al. (1991) is currently the best biostratigraphically constrained magnetostratigraphic study in the Carboniferous, although it is on a condensed succession. Reverse polarity occurs across the Famennian-Tournaisian boundary (base Siphonodella sulcata Zone) with an overlying normal polarity magnetozone (here called MIIn ${ }_{B}$; Fig. 15) beginning in the last part of the S. duplicata Zone in the 
Daposhang section (Fig. 15). A similar polarity pattern (Kolesov 2007) seems to occur in the Kamenka section in NE Russia (Gagiev et al. 1991), and the Kozhim section in the northern Urals, although in the former $\mathrm{MII}_{\mathrm{B}}$ begins in the $S$. sulcata Zone, perhaps indicating an issue with the conodont zonations (Kolesov 2005). This early Tournaisian bias magnetozone $\mathrm{MIIN}_{\mathrm{B}}$ seem to be supported by polarity bias data from igneous rocks (Fig. 15). The magnetozone TB1n from the Tamworth Belt (four sampling levels) is younger than $\mathrm{MI}_{\mathrm{B}}$, since the Lower crenulata Zone occurs in the underlying Brushy Hill Limestone in the sol brachiopod zone (Mory \& Crane 1982; Fig. 4). A sketch outline (without details) of a Tournaisian magnetostratigraphy has also been described by Kolesov (1984), from southern Belgium but other studies have indicated a pervasive early Permian remagnetisation of most Devonian and Carboniferous sediments in Belgium (Thominski et al. 1993; Zegers et al. 2003), so its reliability is unclear.

Overlying magnetozones $\mathrm{MI}_{\mathrm{B}}$ to $\mathrm{MI} 4 \mathrm{n}_{B}$ are zones of polarity bias, since there appear to be no true magnetostratigraphic studies in this interval. Magnetozones $M I 2 n_{B}$ and $M I 4 n_{B}$ seem to be borne out by the equivalent TB1 $n$ and TB2n magnetozones from the New England Orogen Tamworth Belt (Figs. 4,5,

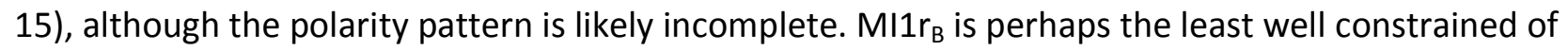
these bias zones, although Kolesov $(2005,2007)$ shows reverse polarity from the Uttykeli and Khurendzha suites, from the Omolon Massif in NE Russia, of mid to late Tournaisian age, similar to that inferred here. The sparse data over the 30 myr interval of the early Tournaisian to the mid Visean has clearly proved a problematic interval for palaeomagnetic studies. The complexity of missing magnetozones in the $\mathrm{MI}_{\mathrm{B}}$ to $\mathrm{MI} \mathrm{A}_{\mathrm{B}}$ bias zones, can only be guessed at, but comparing the polarity in the late Visean from the Australian dataset, with that based on the composite magnetostratigraphy of sections in Fig. 16, likely gives a rough guide (see upper part of Fig. 15).

The key datasets for age constraining a late Visean to Serpukhovian polarity timescale come from the Maritimes Basin and Tengiz, since these have the best age control, and are relatively long records (Fig. 16). For this reason, the following evaluation starts with the most-securely dated younger units, moving to the older, less securely dated, Mauch Chunk Fm.

Major normal magnetozones NN5n and NN6n-NN7n (in Pendleian and Arnsbergian strata), from the Cumberland- W. Cape Breton basins are the likely equivalent of Serpukhovian magnetozones TZ3n and TZ5n from Tengiz (Fig. 16). It is probable that there is part of magnetozone NN7r (Maritimes Basin) and TZ5n (at Tengiz ) missing, close to the top of the Serpukhovian due to hiatus. Underlying magnetozones $N N 5 n$ and TZ3n is a dominantly reverse polarity interval (containing thinner magnetozones NN3n, NN4n and TZ2n), which supports the validity of this correlation. The Brigantian- Pendleian boundary is within the early Serpukhovian (Savastopulo \& Barham 2014), like these magnetostratigraphic correlations also suggest. Within the Serpukhovian, the relative duration and pattern of polarity changes is rather different between Tengiz and the Maritimes Basin, which is most likely due to the hiatus detected in the E. Canadian sections, which bound the Shepody and Claremont formations (Jutras et al. 2015; Fig. 12).

The polarity data from volcanic units at Kinghorn and Derbyshire cover a short, probably mid Asbian to early Brigantian interval, whose ages indicate some overlap (Fig. 16). The reverse polarity in the youngest part of the succession at Kinghorn (intrusive sill-data removed from Fig. 9) is probably the reverse polarity seen in the older lava's in Derbyshire (Fig. 16). Although there are substantial sampling gaps in the Kinghorn succession (Fig. 9), the normal polarity dominance is clear, which appears to be a useful marker (referred to as the MI5n 'marker') for this mid to late Asbian interval. Hence, it is likely From Lucas, Schneider et al. (eds) The Carboniferous Timescale, Spec. Publ. Geol. Soc. Lond. 
the Kinghorn normal polarity interval is the equivalent of the NN1n to NN2n magnetozone interval in the Maritimes Basin (Fig. 16). Maritimes Basin magnetozones NN1- NN2 are potentially late Asbian, if the base of the Middleborough Fm is the lateral equivalent of the Brick-Kiln Limestone in the Maringouin Peninsula- Minudie area as suggested by Jutras et al. (2016). If this Kinghorn to Maritimes Basin correlation is correct, there must be at least three normal magnetozones above in the Brigantian as seen in the Derbyshire data (Fig. 16), so one or more must be missing between the Brigantian and Pendleian age units in the Canadian sections. These relationships provide a basis for correlations in the Brigantian, using the Mauch Chunk data, which occupies this age interval.

The magnetostratigraphy of the Mauch Chunk Fm, whilst probably the longest record of magnetic polarity in the Mississippian, and has two possible age options. The Hometown Mbr may be either within the Morrowan (early Bashkirian) or within the late Chesterian (late Serpukhovian), depending upon the severity of lateral interdigitation with the overlying Pottsville Fm (Fig. 11). Mauch Chunk correlation Option 1 places the Hometown Mbr in the early Bashkirian and Option-2 places this member in the late Serpukhovian (Fig. 16). Option-1 attempts to use the thickness estimates of the Mauch Chunk $\mathrm{Fm}$ as a guide to how much polarity data may be missing in the unsampled interval between MC9n and MC9r. The merit in Option-1 is the reverse polarity dominance in the TZ1r-TZ2r interval (at Tengiz), is like that seen between MC6r to MC8r (Fig. 16). Also in the youngest parts, a tentative reverse polarity magnetozone (probable equivalent of MC11r) is seen in TZ6n at Tengiz (Figs. 13, 16).

In the lower part of the Indian Run Mbr, magnetozone MC4n is likely the equivalent of the NN1n-NN2n and Kinghorn- normal polarity interval (the chron MI5n 'marker'; Fig. 16). This would be compatible with the lower placement of the Loyalhanna Mbr in the Mauch Chunk Fm (like shown in Fig. 11), as a proxy for the base of the Chesterian (base Chesterian equates to base of foraminifera zone MFZ14; Poty et al. 2006 and base of the late Asbian, Cf6 $\delta$ Biozone; Cozar \& Somerville, 2004). The correlation alternative of placing the Loyalhanna Mbr in the mid part of the Mauch Chunk Fm (and so the base Chesterian) seems unlikely, since the Asbian and Brigantian strata from other studies would need to fit within the mid and missing part of the Indian Run Mbr (Fig. 16).

Mauch Chunk correlation Option-2 is similar to that used by Opdyke et al. (2014) to interrelate the Martimes Basin and Mauch Chunk datasets, and conveniently places the base of the Pottsville Fm close to the base of the Bashkirian. This is the preferred option here, and the polarity composite is constructed using this in Fig. 16. Between the MI5n 'marker' and MC10n three normal magnetozones are seen in the Derbyshire data and five in the Mauch Chunk Fm (although conceivably more may be present in the unsampled mid part of the Indian Run Mbr). Mauch Chunk correlation Option 2 minimizes the amount of missing thickness and magnetozones in both the Maritimes Basin and Mauch Chunk data. This correlation option indicates the relatively short duration of NN7r and equivalents (e.g. MC11r, MI9r). However, with this option there is no constraint on the relative thickness of magnetochron PE1n, which may be relatively longer than shown on the polarity composite. However, the Tengiz carbon isotope data compared to the Askyn River section, suggests little is missing at this boundary (Fig. 14).

Opdyke et al. (2000) was rather ambiguous about how the normal polarity intervals in the lower part of the Clifden Fm from the Rocky Creek Syncline (Fig. 6) may relate to other data and age, since much depends on the SHRIMP dates from these successions, and the Carboniferous timescale. The original From Lucas, Schneider et al. (eds) The Carboniferous Timescale, Spec. Publ. Geol. Soc. Lond. 
SHRIMP date for the Wanganui Andesite was 319.2 $\pm 2.8 \mathrm{Ma}$ (Fig. 6), but using the corrections of Black et al (2003a) gives 322.4 $\pm 2.9 \mathrm{Ma}$ Ma for the andesite. Using the array of SHRIMP dates from 325 to $\sim 321 \mathrm{Ma}$ from the Clifden Fm, and Arnsbergian U-Pb dates of $324-325 \mathrm{Ma}$ (Pointon et al. 2012; Jirasek et al., 2018) would push the base of this formation to around the Serpukhovian- Bashkirian boundary, shown as Option A in Fig. 16. The alternative, based only on the magnetostratigraphy would suggest Option B in Fig. 17. The succession of corrected SHRIMP dates from the Rocky Creek Syncline sections fits rather better with Option A in Fig. 16, which would place the Clifden Fm in the Late SerpukhovianEarly Bashkirian. The anomalously young corrected SHRIMP date of $317.8 \pm 1.9 \mathrm{Ma}$ in the upper part of the Clifden Fm may relate to problems in correlating the Lochiel Downs- Darthula section (Fig. 6) and uncertainties in the constraining SHRIMP-based age control (Roberts et al. 2003a).

\section{Pennsylvanian}

The Tengiz carbon isotope correlations suggest that magnetozone TZ6n occupies the early to mid part of the Akavasian (Fig. 14), with the magnetostratigraphy not extending to the base Askynbashian at Tengiz. In the Donets Basin data the equivalent Sverokeltmenian-Prikmian boundary (Figs. 1, 14) occurs within the magnetozone DB1n, with an underlying reverse polarity interval in the Sverokeltmenian (i.e. Akavasian at Tengiz; Fig. 14b). This indicates that the reverse interval underlying DB1n is magnetochron PE2r (Fig. 17). The relative thickness of PE2 $r$ is unconstrained in any section. losifidi \& Khramov (2013) also seemed to have detected PE2 $n$ and the underlying reverse magnetozone PE1 $r$ from Spitsbergen sections, although sampling and stratigraphic details are insufficient to be sure. Reverse and normal polarity intervals of Morrowan age (early Bashkirian) were also confirmed by Nick et al. (1991) on reddened palaeosols from the Black Prince Limestone from SW Arizona, but stratigraphic details are insufficient to link to the data in Fig. 17.

Equivalent age magnetozones to the Donets Basin magnetozone DB1n are known from the Maritimes Basin (Fig. 17). Opdyke et al. (2000) proposed that the Wanganui 'reversal' (Figs. 16, 17) represents the start of the Kiaman Superchron, although based on the corrected SHRIMP dates, this is too old, since the Wanganui reversal probably represents the base of PE1r (Fig. 16). Russian workers have long considered the Kiaman Superchron to start at the top of magnetozone DB5n in the Donets Basin (Fig. 1; Khramov \& Rodionov 1980). This placement had probably evolved from Irving \& Parry's (1963) placement of the base of the Kiaman in the "Westphalian or between the Westphalian and Stephanian", that was based on data from the better-dated European data at the time. A placement of the base Kiaman around the Namurian-Westphalian boundary (mid Bashkirian) was also proposed by Irving \& Pullaiah (1976), consistent with that proposed here below.

\section{Late Bashkirian, Moscovian and younger}

We have seen that several lines of evidence from other studies have suggested the potential reliability of most parts of the magnetostratigraphy from the Donets Basin (Fig. 1) of Khramov et al. (1974). These include, similar palaeomagnetic mean directions, using modern demagnetization techniques (losifidi et al. 2010, 2016) and the multi-section nature of the original data (Fig. 1). Evidence has been previously examined that suggests that normal polarity intervals from igneous rocks may represent the equivalent of magnetochrons in the late Bashkirian- Moscovian. In addition, a probable Langsettian age normal magnetozone in the New Scotland Fm in Nova Scotia (Buchan \& Chandler 1999) is the probable equivalent of magnetochron PE4n and DB2n (Fig. 17). This range of support suggests that the Bashkirian to Moscovian magnetic polarity data of Khramov et al. (1974) probably provides the best record (at this

From Lucas, Schneider et al. (eds) The Carboniferous Timescale, Spec. Publ. Geol. Soc. Lond. 
time) of polarity changes through the early and mid Pennsylvanian, in spite of its short-comings with respect to out-dated demagnetization techniques.

In addition, Kim et al. (1992), Doh \& Piper (1994) and Lee et al. (1996) have found both polarities in palaeopoles-type datasets (directions passing a fold test) from South Korean Moscovian age red beds of the Manhang and Yobong formations and Hongjom Series of the Pyongan Supergroup (Lee 2010; Table 2; Fig. 17b). Their sample sets are dominated by reverse polarity but with around $5 \%-15 \%$ of the samples showing normal polarity. Those data from the Manhang Fm are from the lower parts of the formation. These Korean Carboniferous magnetizations are challenging to isolate from later remagnetisations, but the careful rock-magnetic and demagnetisation procedures employed by Lee et al. (1996) clearly allowed their isolation. These formations are primarily early Moscovian (primarily based on fusulinids; Lee 2010), but the lower parts of the Yobong Fm may extend into the late Bashkirian, so the normal polarity intervals could be the equivalent to DB3n or DB4n (chrons PE5n, PE6n) in the Donets Basin (Figs. 1, 17). The Shatterford sill and Karkonosze granite dual polarity datasets may also be the equivalent of DB4n and PE6n (Table 1; Fig. 17b).

The Kasimovian was widely thought to be entirely reversed polarity, even in the Russian compilations (Fig. 2), yet palaeopoles type studies from Argentina, China and E. Canada (Tables, 1,2; Fig. 17) show a grouping with less than $100 \%$ reverse polarity at about $305 \mathrm{Ma}$. In the Kasimovian to Gzhelian age Dzhingilsaj section (Ferghana, Uzbekistan) the oldest two levels were also interpreted as normal polarity (Davydov \& Khramov 1991). These two levels span the Montiparus montiparus and Protriticites psudomomontiparus- Obsoletes obsoletes foraminifera zones in the mid Kasimovian, adding further support to a probable normal polarity interval in the mid Kasimovian. This is referred to as polarity bias zone PE8 $\mathrm{n}_{\mathrm{B}}$, since most support is from polarity bias data (Fig. 17b).

The late Gzhelian contains a brief normal magnetozone, named the "Kartamyshian" by Davydov \& Khramov, (1991), for which there is evidence from other palaeopole-type studies and several magnetostratigraphic studies (reviewed by Hounslow \& Balabanov 2018). Hounslow \& Balabanov (2018) referred to this as $\mathrm{Cl} 1 \mathrm{n}$, the base of their magnetochron numbering scheme for the Cisuralian.

However, other studies (e.g. Steiner 1988) have failed to find normal polarity intervals in the Late Bashkirian to Gzhelian, such as Opdyke et al. (2000) from the New England Tamworth Belt (Fig. 17) and Opdyke et al. (2014) from the Moscovian to Gzhelian Spring valley \#1 Core (Nova Scotia). Magnus \& Opdyke (1991) collected 197 samples from 1280 m of the Minturn Fm of late Atokan-Desmoinesian age (mostly Moscovian, Itano et al. 2003) from the Arkansas River Valley in Colorado and found only reversed polarity. In addition, Diehl and Shive (1981) detected no normal polarity in 549 samples covering $86 \%$ of the Casper Fm in Wyoming. Based on fusulinids the Casper Fm ranges in age from the late Desmoinesian through Missourian and Virgilian (most of Kasimovian-Gzhelian) and into the earliest Permian (Burns \& Nestell 2009), although possible hiatuses may be present (Diel \& Shive 1981).

This conflicting situation is much like the early Permian, where there is evidence for some brief normal polarity intervals, but some detailed-sampling in red-bed based magnetostratigraphic studies have failed to detect any normal polarity (Hounslow \& Balabanov 2018). The reasons for the between-study disparities are un-resolved. In some cases it may be due to stratigraphic complexity due to hiatus, or the logistical difficulty of sampling and so finding, brief normal polarity intervals, in a dominance of reverse From Lucas, Schneider et al. (eds) The Carboniferous Timescale, Spec. Publ. Geol. Soc. Lond. 
polarity. However, it most likely relates to the mechanisms of haematite generation in red-beds, which can be both short-term (at or close to time of deposition; Besly \& Turner 1983; Turner et al. 1985), as well as long term lasting millions of years (Larson et al. 1982; Johnson et al. 1997). Resolving this issue for the Kiaman Superchron goes to the crux of the 'superchron paradigm', in which exclusively singlepolarity intervals are thought to punctuate earth history (Driscoll \& Evans, 2016).

\section{A geomagnetic polarity timescale}

A magnetochron age model for the interval between magnetochrons MI4r and PE7r is constructed using the methods proposed by Hounslow (2016), and used by Hounslow \& Balabanov (2018) and Hounslow et al. (2018). This firstly generates a statistical composite of the magnetostratigraphic data in an arbitrary section-height scale (Hounslow 2016). Data used is from the Mauch Chunk (all 4 sub-sections, Fig. 10), Tengiz, Donets Basin (3 sub-sections, Fig. 1) and Maritimes Basin. In the Maritimes Basin data (Fig. 16) the Middleborough, Claremont Fm and the Port Hood Fm data are only used, since in the compositing process, other section data do not constrain the relative thickness of any magnetochron. The Rocky Creek Syncline data from the Clifden Fm and Ermelo Pyroclastics is not used because of the age and correlation uncertainty, and the irregular sampling. There are three magnetozones PE1n, PE2n and PE2r without a relative thickness constraint. To constrain PE1 $n$, the base of PE1r is placed at the top of the Mauch Chunk Fm Lavelle section (Beury Road; Fig. 10). To constrain PE2n and PE2r the base of PE2r is placed at the base of the Davidovka section in the Donets Basin (Fig. 1). The conversion of the statistical composite to time should partly correct for any distortions introduced by these unconstrained magnetozones. A linear sediment accumulation model is used for all sections (Hounslow 2016), and the statistical optimization procedure shows that the Port Hood Fm and the Middleborough have the poorest overall match ( $D_{j}$ of 0.28 and 0.13 respectively; Fig. 18; Hounslow 2016). The overall optimization mis-match across all sections is around $8 \%\left(D_{s}=0.078\right.$; Figs. 18a, b). Additional magnetozone constraints at formation top were used for the Claremont and Middleborough formations (MI9r, MI6r.1n respectively), and at formation bases for the Port Hood and Middleborough formations (PE3n.1n, MI5n.1n respectively), and section base at Tengiz (MI7n.1r). The magnetozones at Tengiz were sectioned into two sets at the Serp_SSB disconformity (Figs. 16, 18).

$\mathrm{U}-\mathrm{Pb}$ radioisotopic dates are attached to the polarity scale as detailed in Table 3 , as shown on the magnetochron scale in Figs. 16 and 17, and displayed with their uncertainty in Fig. 18c. To derive the magnetochron ages a Bayesian method (Haslett \& Parnell 2008; Parnell et al. 2008) is used as implemented in the Bchron functions in R. This constructs an age model from piecemeal linear segments, simulating sedimentation by small increments, random in duration and sedimentation rate. The method handles radioisotopic date uncertainties (as normally distributed values, $\sigma_{R} ;$ Table 3 ) and uses procedures to deal with radioisotopic date outliers, flagging dates with a probability of being an outlier ( $\mathrm{P}_{\text {out }}$ in Table 3 ). The measure of stratigraphic uncertainty in placing the radioisotopic date onto the optimised composite scale is also included (i.e. $e_{s}$; Hounslow 2016; Table 3), as the 'uniform range' $\left(d_{\max }-d_{\min }\right.$ of Parnell et al. 2008). The uncertainty on each of the magnetozones derived from the initial statistical compositing procedure is scaled to $\mathrm{Ka}$ as $\pm \sigma_{T}$ in Fig. 18a, using the appropriate magnetochron duration from the age model. These methods therefore incorporate all the major uncertainties into the final GPTS (Fig. 18c, Table 4). $\sigma_{\text {T }}$ can be thought of as a kind of inter-section magnetozone placement uncertainty, which is impacted by between-section changes in sedimentation rate and sampling density. 
Confidence intervals ( $C_{95}$, Fig. 19d) on the magnetochron ages are obtained from Monte-Carlo simulations, using the $95 \%$ highest posterior density region (HPD) from the age model (Haslett \& Parnell 2008; Fig. 18c; Table 4). The HPD represents the shortest interval of time that encompasses $95 \%$ of the simulations (Parnell et al., 2011). The HPD confidence intervals $\left(C_{95}\right)$ may be overly pessimistic in intervals without age control points (Blaauw \& Christen 2011), which is to some extent expressed by the generally lower $2 \sigma_{T}$ compared to $C_{95}$ (Fig. 19c,d). Those magnetochrons outside the MI4r and PE7r interval have their base ages estimated as outlined in Table 4, and shown in Fig. 19a. The scaling to age rather compresses the mid Bashkirian magnetozones and expands the late Serpukhovian magnetozones (Fig. 18c). The differences between the estimated age of stage bases here (Fig. 19a) and those of Aretz et al. (2020) relate to the different scaling methods and where the radioisotopic dates are attached to that scale.

The percent reverse polarity using a four-chron wide window (with magnetochron durations), clearly shows the polarity dominance switch-over into the base of the Kiaman Superchron at 319-317 Ma. The midpoint of the polarity bias change (using mid way between the 20 and $80 \%$ shoulders of \%reverse polarity; Fig. 18d) is within PE3r, so the proposed base of the Kiaman Superchron is at the base of PE3r.1r at 318.6 $\pm 0.33 \mathrm{Ma}$ (Fig. 19a, Table 3). This mid-point approach is similar to that used by Haneda et al. (2020) to place the Matuyama-Brunhes boundary within its transition interval. The end of the Kiaman Superchron is in the mid Permian at $266.66 \pm 0.76 \mathrm{Ma}$ (Hounslow \& Balabanov, 2018). Although normal polarity intervals have long been suspected in the Kiaman Superchron since the early days of palaeomagnetism (Irving \& Pullaih 1976), many researchers have persisted with the concept of a $100 \%$ reverse polarity superchron (e.g. Opdyke 1995; Pavlov \& Gallet, 2005 ), like that originally envisaged by Irving \& Parry (1963). Evidence presented here and in Hounslow \& Balabanov (2018) indicate that there is strong evidence for normal magnetozones in the Kiaman Superchron, which hopefully will spur further studies to fully validate their existence, and utilize them for detailed stratigraphic studies.

\section{Conclusions}

The development of a Carboniferous GPTS has shown hesitant progress over the last 60 years, partly dictated by modifications in the sediment magnetisation paradigms that apply to Carboniferous sediments, concomitant with recognition of remagnetisations. Improvements in instrument sensitivity and data analysis and the key contributions of Neil Opdyke have also played a significant part in this progress. Geomagnetic polarity changes in the Carboniferous are currently one of the least well understood parts of the Palaeozoic. However, there are insufficient magnetostratigraphic and palaeomagnetic data to attempt a full, detailed polarity zonation of the entire Carboniferous (Fig. 19a). However, a preliminary set of 37 magnetozones can be identified in the Mississippian and 28 in the Pennsylvanian. This first comprehensive review, takes a bottom-up approach by integrating all biostratigraphic, chemostratigraphic and radioisotopic data with the connected geomagnetic polarity information.

For most of the Tournaisian and into the mid Visean, geomagnetic polarity is only known in outline, largely based on studies from the Tamworth Belt of the New England Orogen in E. Australia and polarity bias data from some other studies. This age interval can best be characterized by polarity bias magnetochrons ( $M I 1 n_{B}$ to $M I 4 n_{B}$ ), which have an implicit assumption that the polarity pattern in these is almost certainly incomplete (grayed intervals in Fig. 19a). If the reversal rate in the Tournaisian to mid 
Visean is like the younger parts of the Carboniferous, there may be a minimum ca. 40 other magnetozones to discover in the initial $23 \mathrm{Ma}$ of the Mississippian.

The interval from the late Visean to the late Moscovian has a fuller dataset of polarity changes, which allows a reasonable estimate of geomagnetic polarity to be made, and related to a set of 31 radioisotopic dates to generate a GPTS. Two short intervals at the Serpukhovian-Bashkirian boundary and in the late Akavasian substage (Marsdenian substage), have an incompletely known pattern of polarity changes. The late Brigantian may also have an incomplete polarity pattern. The various parts of the procedures leading to the final GPTS, allow uncertainties from the intersection composite to be specified as $\sigma_{\mathrm{T}}$ (Fig. 19c), as well as confidence interval on the chron ages to be specified as $C_{95}$ (Fig. 19d).

The base of the Kiaman Superchron at magnetochron PE3r is placed in the mid Bashkirian within the Yeadonian and Prikamian substages, rather than using the traditional Russian position in the late Moscovian. Conventional palaeomagnetic studies supported by the Donets Basin magnetostratigraphy clearly show that the Kiaman Superchron is not exclusively reverse polarity, but has at least eight normal polarity chrons within it. An additional bias magnetochron PE8 $n_{B}$, is present in the mid Kasimovian.

Sediment-based magnetostratigraphic data from red-beds has been a key, but not exclusive, source of data in this review. Future improvements need to move to sediment successions which have a better biostratigraphy, or thick lava successions with good geochronological control. Probably the previous strong focus on red-beds has created some of the misconceptions about the $100 \%$ reverse polarity state of the Kiaman Superchron, which may in part be due to the undeniably prolonged haematite diagenesismagnetisation processes in some types of red-beds. The resulting polarity changes throughout the Carboniferous, provides a rich set of chronostratigraphic markers to help solve many (e.g. glaciallyrelated) environmental problems that require high stratigraphic resolution at the global scale.

\section{Acknowledgements}

Ken Ratcliffe (Chemostrat Ltd), Michael Urbat (Robertson -CGG), and Ted Playton (Chevron) are thanked for access to the AAPG presentation information of the Tengiz dataset, and allowing its publication. Vassil Karloukovski provided Russian translations. Pedro Cózar shared outcomes of unpublished foraminiferal work. Reviewers Markus Aretz and Jim Ogg provided much constructive comment.

\section{References}

ADDISON, F. T. 1982. A magnetic study of diagenesis in carbonate sediments. Unpubl. PhD thesis, University of Newcastle upon Tyne.

ADDISON, F.T., TURNER, P. \& TARLING, D.H. 1985. Magnetic studies of the Pendleside Limestone: evidence for re-magnetisation and late diagenetic dolomitisaton during a post Asbian normal event. J. Geol. Soc. Lond., 142, 983-994.

AITKENHEAD, N., CHISHOLM, J. I. \& STEVENSON, I. P. 1985. Geology of the country around Buxton, Leek, and Bakewell, Memoir for 1:50,000 geological Sheet 111 (England \& Wales), BGS, HMSO.

AKIMOTO, S. I. \& KUSHIRO, I. 1960. Natural occurrence of titanomaghemite and its relevance to the unstable magnetization of rocks. Journal of Geomagnetism \& Geoelectricity, 11, 94-110.

From Lucas, Schneider et al. (eds) The Carboniferous Timescale, Spec. Publ. Geol. Soc. Lond. 
ALGEO, T. J. 1996. Geomagnetic polarity bias patterns through the Phanerozoic. Journal of Geophysical Research: Solid Earth, 101, 2785-2814.

ALLAN, D. A. 1923. The Igneous Geology of the Burntisland District. PhD, University of Edinburgh. https://era.ed.ac.uk/handle/1842/26879

ALLEN, J. P., FIELDING, C. R., GIBLING, M. R. \& RYGEL, M. C. 2011. Fluvial response to paleo-equatorial climate fluctuations during the late Paleozoic ice age. GSA Bulletin, 123, 1524-1538.

AL-TAWIL, A., WYNN, T.C. \& READ, J.F. 2003. Sequence response of a distal-to-proximal foreland ramp during Mississippian glacioeustasy, Appalachian Basin, eastern U.S.A. In: AHR, W.M., HARRIS, P.M., MORGAN, W.A., SOMERVILLE, I.D. (Eds.), Permo-Carboniferous Carbonate Platforms and Reefs. Soc. Econ. Paleontol. Mineral., Spec. Publ., 78, 9-32.

AMENNA, M., DERDER, M. E. M., HENRY, B., BAYOU, B., MAOUCHE, S., BOUABDALLAH, H., OUABADI , A., AYACHE, C.M. \& BEDDIAF, C. M. 2014. Improved Moscovian part of the Gondwana APWP for paleocontinental reconstructions, obtained from a first paleomagnetic pole, age-constrained by a fold test, from In Ezzane area in the Murzuq basin (Algeria, stable Africa). Journal of African Earth Sciences, 99, 342-352.

ANDERSON, K.L., LACKIE, M.A., CLARK, D.A. \& SCHMIDT, P.W. 2003. Paleomagnetism of the Newcastle range, northern Queensland: Eastern Gondwana in the late Paleozoic. Jour. Geophys. Res., 108, doi: 10.1029/2002JB001921.

Aretz, M. et al. 2020. The Carboniferous Period. In: Gradstein, F.M., Ogg, J.G., Schmitz, M., Ogg, G.M. (Eds). Geologic Time scale 2020, Vol. 2. Elsevier, pp. xx-yy.

AS, J. A. \& ZIJDERVELD, J. D. A. 1958. Magnetic cleaning of rocks in palaeomagnetic research. Geophys. J. R. astro. Soc., 1, 308-319.

ASUD 2020. Australian Stratigraphic Units Database. https://asud.ga.gov.au/

BATT, L. S., MONTAÑEZ, I. P., ISAACSON, P., POPE, M. C., BUTTS, S. H. \& ABPLANALP, J. 2007. Multicarbonate component reconstruction of mid-Carboniferous (Chesterian) seawater $\delta^{13} \mathrm{C}$. Palaeogeography, Palaeoclimatology, Palaeoecology, 256, 298-318.

BAXTER, A. N. \& MITCHELL, J. G. 1984. Camptonite-Monchiquite dyke swarms of Northern Scotland; Age relationships and their implications. Scottish Journal of Geology, 20, 297-308.

BAZHENOV, M. L., COLLINS, A. Q., DEGTYAREV, K. E., LEVASHOVA, N. M., MIKOLAICHUK, A. V., PAVLOV, V. E. \& VAN DER VOO, R. 2003. Paleozoic northward drift of the North Tien Shan (Central Asia) as revealed by Ordovician and Carboniferous paleomagnetism. Tectonophysics, 366, 113-141.

BECK JR, M. E., GARCIA R, A., BURMESTER, R. F., MUNIZAGA H, F., HERVÉ A, F. \& DRAKE, R. E. 1991. Paleomagnetism and geochronology of late Paleozoic granitic rocks from the Lake District of southern Chile: Implications for accretionary tectonics. Geology, 19, 332-335.

BELSHÉ, J. C. 1957. Palaeomagnetic investigations of Carboniferous rocks in England and Wales. Advances in Physics, 62, 187-191.

BERG, T. M., MCINERNEY, M. K., WAY, J. H. \& MACLACHLAN, D. B. 1983. Stratigraphic correlation chart of Pennsylvania. Pennsylvania Geological Survey, General Geology Report 75.

BESLY, B. M. \& TURNER, P. 1983. Origin of red beds in a moist tropical climate (Etruria Formation, Upper Carboniferous, UK. In: WILSON R.C.L. (ed.), Residual Deposits: Surface Related Weathering Processes and Materials, Geological Society, London, Special Publications, 11, 131-147.

BIRGENHEIER, L. P., FIELDING, C. R., RYGEL, M. C., FRANK, T. D. \& ROBERTS, J. 2009. Evidence for dynamic climate change on sub-106-year scales from the late Paleozoic glacial record, Tamworth Belt, New South Wales, Australia. Journal of Sedimentary Research, 79, 56-82.

BLACK L.P., KAMO S.L., WILLIAMS I.S., MUNDIL R., DAVIS D.W., KORSCH R.J. \& FOUDOULIS C. 2003a. The From Lucas, Schneider et al. (eds) The Carboniferous Timescale, Spec. Publ. Geol. Soc. Lond. 
application of SHRIMP to Phanerozoic geochronology; a critical appraisal of four zircon standards. Chemical Geology, 200, 171-188.

BLAAUW, M. \& CHRISTEN, J. A. 2011. Flexible paleoclimate age-depth models using an autoregressive gamma process. Bayesian analysis, 6, 457-474.

BLAKEY, R. C. \& MIDDLETON, L. T. 2012. Geologic history and paleogeography of Paleozoic and early Mesozoic sedimentary rocks, eastern Grand Canyon, Arizona. Spec. Pap., Geol. Soc. Am, 489, 81-92.

BRENCKLE, P. L. \& MILKINA, N. V. 2003. Foraminiferal timing of carbonate deposition on the Late Devonian (Famennian)-Middle Pennsylvanian (Bashkirian) Tengiz Platform, Kazakhstan. Rivista Italiana di Paleontologia e Stratigrafia, 109, 131-158.

BREZINSKI, D. K. 1989a, Late Mississippian depositional patterns in the north-central Appalachian Basin, and their implications to Chesterian hierarchal stratigraphy. Southeastern Geology, 30, 1-23.

BREZINSKI, D. K. 1989b. The Mississippian System in Maryland, 52, Dept. of Natural Resources, Maryland Geological Survey. http://www.mgs.md.gov/publications/report_pages/RI_52.html

BREZINSKI, D. K. 1999. Chapter 9, Mississippian, In: Shultz, C. H. (ed.) The Geology of Pennsylvania. Pennsylvania Geological Survey \& Pittsburgh Geological Society, 139-147.

BREZINSKI, D. K. 2009. Biostratigraphic Distribution of Appalachian Carboniferous Trilobites. In: GREB

S.F. \& CHESNUT Jr. D. R. (eds). Carboniferous of the Appalachian and Black Warrior Basins.

Kentucky Geological Survey Special Publication, 10, 78-84.

BRIAND, C., IZART, A., VASLET, D., VACHARD, D., MAKHLINA, M., GOREVA, N., ISAKOVA, T., KOSSOVAYA, O. \& JAROSHENKO, A. 1998. Stratigraphy and sequence stratigraphy of the Moscovian, Kasimovian and Gzhelian in the Moscow Basin. Bulletin de la Société géologique de France, 169, 35-52.

BRIDGE, D. \& GOZZARD, M.C.C. 1981. The limestone and dolomite resources of the country around Bakewell, Derbyshire. Description of 1:25000 sheet SK 26 and part of SK27. Mineral Assessment report. British Geol. Survey, HMSO. https://webapps.bgs.ac.uk/data/publications

/pubs.cfc?method=viewRecord\&publnId=19867658

BRINDLEY, S. \& SPINNER, E. 1989. Palynological assemblages from Lower Carboniferous deposits, Burntisland district, Fife, Scotland. Proceedings of the Yorkshire Geological Society, 47, 215-231.

BROWNE, M.A.E., DEAN, M.T., HALL, I.H.S., MCADAM, A.D., MONRO, S.K. \& CHISHOLM, J.I. 1999. A lithostratigraphical framework for the Carboniferous rocks of the Midland Valley of Scotland. British Geological survey research Report, RR/99/07.

BRYNJÓLFSSON, A. 1957. Studies of remanent magnetism and viscous magnetism in the basalts of Iceland. Advances in Physics, 62, 247-254.

BUCHAN, K. L. \& CHANDLER, F. W. 1999. Paleomagnetism of the Distal Member of the New Glasgow Formation, Nova Scotia, Canada: new constraints on magnetic polarity stratigraphy near the base of the Kiaman Superchron. Journal of Geology, 107, 271-286.

BURNS, D. M. \& NESTELL, M. K. 2009. Using fusulinids to evaluate the periodicity of cycles in a sequence stratigraphic section of Pennsylvanian-Permian strata and to suggest possible support for lowfrequency milankovitch perturbations: Casper Formation, southeastern Wyoming, USA. In: DEMCHUK, T.D. \& GARY, A.C. (eds.) Geologic Problem Solving with Microfossils: A Volume in Honor of Garry D. Jones, SEPM Special Publication, 93, 253-267.

BUTCHER, N. J. D. \& FORD, T. D. 1973. The Carboniferous Limestone of Monsal Dale, Derbyshire. Mercian Geologist, 4, 179-195.

BUTTERWORTH, M. A. \& BUTCHER, C. E. 1983. Basal Dinantian miospores from the Cockermouth area, West Cumbria. Journal of Micropalaeontology, 2, 13-16.

CASINI, L., CUCCURU, S., MAINO, M., OGGIANO, G. \& TIEPOLO, M. 2012. Emplacement of the Arzachena From Lucas, Schneider et al. (eds) The Carboniferous Timescale, Spec. Publ. Geol. Soc. Lond. 
Pluton (Corsica-Sardinia Batholith) and the geodynamics of incoming Pangaea. Tectonophysics, 544, 31-49.

CÉSARI, S. N., LIMARINO, C. O. \& GULBRANSON, E. L. 2011. An Upper Paleozoic bio-chronostratigraphic scheme for the western margin of Gondwana. Earth-Science Reviews, 106, 149-160.

CHAMALAUN, F. H. 1964. Origin of the secondary magnetization of the old red sandstones of the Anglo-Welsh cuvette. Journal of Geophysical Research, 69, 4327-4337.

CHAMALAUN, F. H. \& CREER, K. M. 1964. Thermal demagnetization studies on the old red sandstone of the Anglo-Welsh Cuvette. Journal of Geophysical Research, 69, 1607-1616.

CLEGG, J. A., ALMOND, M. \& STUBBS, P. H. S. 1954, The remanent magnetism of some sedimentary rocks in Britain: Philos. Mag., Ser. 7, 45, 583-598.

CLEGG, J. A., DEUTSCH, E. R., EVERITT, C. W. F. \& STUBBS, P. H. S. 1957. Some recent palaeomagnetic measurements made at Imperial College, London: Advances in Physics, 6, 219-231.

COGNÉ, J. P. 1988. Strain-induced AMS in the granite of Flamanville and its effects upon TRM acquisition. Geophysical Journal, 92, 445-453.

COLLINS, J. F., KENTER, J. A. M. HARRIS, P. M., KUANYSHEVA, G., FISCHER, D. J. \& STEFFEN, K. L. 2006. Facies and reservoir-quality variations in the late Visean to Bashkirian outer platform, rim, and flank of the Tengiz buildup, Precaspian Basin, Kazakhstan, In: HARRIS, P. M. \& WEBER, L. J. (eds.), Giant hydrocarbon reservoirs of the world: From rocks to reservoir characterization and modelling: AAPG Memoir 88/SEPM Special Publication, p. 55-95.

COX, F.C \& HARRISION D.J. 1980. The limestone and dolomite resources of the country around Wirksworth, Derbyshire. 1:25000 sheets SK25 (and SK35), Mineral assessment report 47, British Geol . Survey, HMSO.

COX, A. 1957. Remanent magnetization of lower to middle Eocene basalt flows from Oregon. Nature, 179, 685-686.

COX, A. \& DOELL, R. R. 1960. Review of paleomagnetism. Geological Society of America Bulletin, 71, 645768.

CÓZAR, P., \& SOMERVILLE, I. D. 2004. New algal and foraminiferal assemblages and evidence for recognition of the Asbian-Brigantian boundary in northern England. Proceedings of The Yorkshire Geological Society, 55,43-65.

CÓZAR, P., SOMERVILLE, I. D. \& BURGESS, I. 2008. New foraminifers in the Visean /Serpukhovian boundary interval of the Lower Limestone Formation, Midland Valley, Scotland. Journal of Paleontology, 82, 906-923.

CLAYTON, G. \& TURNAU, E. 1990. Correlation of the Tournaisian miospore zonations of Poland and the British Isles. Annales Societatis Geologorum Poloniae, 60, 45-58.

COLLINSON, D. W. \& RUNCORN, S. K. 1960. Polar wandering and continental drift: evidence from paleomagnetic observations in the United States. Geological Society of America Bulletin, 71, 915958.

CRAGGS, S., KEIGHLEY, D., WALDRON, J. W. \& PARK, A. 2017. Salt tectonics in an intracontinental transform setting: Cumberland and Sackville basins, southern New Brunswick, Canada. Basin Research, 29, 266-283.

CREER, K. M. 1957. IV. The natural remanent magnetization of certain stable rocks from Great Britain. Philosophical Transactions of the Royal Society of London. Series A, Mathematical and Physical Sciences, 250, 111-129.

CREER, K. M. 1958. Preliminary paleomagnetic measurements from South America. Annales de Géophysique 14, 373-389.

From Lucas, Schneider et al. (eds) The Carboniferous Timescale, Spec. Publ. Geol. Soc. Lond. 
CREER, K. M. 1959. AC demagnetization of unstable Triassic Keuper Marls from SW England. Geophysical Journal International, 2, 261-275.

DAVYDOV, V. I., CROWLEY, J. L., SCHMITZ, M. D. \& POLETAEV, V. I. 2010. High-precision U-Pb zircon age calibration of the global Carboniferous time scale and Milankovitch band cyclicity in the Donets basin, eastern Ukraine. Geochemistry, Geophysics, Geosystems, 11 Q0AA04, doi:10.1029/2009GC002736

DAVYDOV, V.I. \& KHRAMOV, A.N. 1991 Paleomagnetism of Upper Carboniferous and Lower Permian in the Karachatyr region (southern Ferhgana) and the problems of correlation of the Kiama hyperzone. In: KHRAMOV, A.N. (Ed.) Paleomagnetism and paleogeodynamics of the territory of USSR. Transactions of VNIGRI, p. 45-53 (In Russian).

DAVYDOV, V. I. \& LEVEN, E. J. 2003. Correlation of Upper Carboniferous (Pennsylvanian) and Lower Permian (Cisuralian) marine deposits of the Peri-Tethys. Palaeogeography, Palaeoclimatology, Palaeoecology, 196, 39-57.

DAVYDOV, V. I., KORN, D. \& SCHMITZ, M. D. 2012. The Carboniferous Period. In: GRADSTEIN, F.M., OGG, J. G., SCHMITZ, M. \& OGG, G. (Eds.). The geologic time scale 2012. Elsevier. Pp. 616-655.

DECKART, K., HERVÉ ALLAMAND, F., FANNING, M., RAMÍREZ, V., CALDERÓN, M. \& GODOY, E. 2014. U$\mathrm{Pb}$ geochronology and $\mathrm{Hf}-\mathrm{O}$ isotopes of zircons from the Pennsylvanian Coastal Batholith, southcentral Chile. Andean Geology 41, 49-82.

DERDER, M. E., HENRY, B., AMENNA, M., BAYOU, B., DJELLIT, H., GUEMACHE, M. A. \& HEMMI, A. 2009. New structural implications for the central Sahara (Algeria), from the revisited Upper Carboniferous 'Hassi Bachir' formation: paleomagnetic constraints. Tectonophysics, 463, 69-76.

DERDER, M.E.M., SMITH, B., HENRY, B., YELLES, A.K., BAYOU, B., DJELLIT, H., OUALI, R, GANDRICHE, H. 2001. Juxtaposed and superimposed palaeomagnetic primary and secondary components from the folded Middle Carboniferous sediments in the Reggane basin (Saharan Craton, Algeria. Tectonophysics, 344, 403-422.

DERDER, M. E. M., HENRY, B., BAYOU, B., OUABADI, A., BELLON, H., DJELLIT, H., KHALDI, A., AMENNA M., BAZIZ K., HEMMI, A. \& GUEMACHE, M. A. 2006. New African Lower Carboniferous paleomagnetic pole from intrusive rocks of the Tin Serririne basin (Southern border of the Hoggar, Algeria. Tectonophysics, 418, 189-203.

DIEHL, J. F. \& SHIVE, P. N. 1981. Paleomagnetic results from the late Carboniferous/early permian casper formation: implications for northern Appalachian tectonics. Earth \& Planetary Science Letters, 54, 281-292.

DIETZEL, G. F. L. 1960. Geology and Permian paleomagnetism of the Merano region, province of Bolzano, N. Italy, Unpubl. Phd., Utrecht University.

DIVENERE, V. J. \& OPDYKE, N. D. 1991a. Magnetic polarity stratigraphy in the uppermost Mississippian Mauch Chunk formation, Pottsville, Pennsylvania. Geology, 19, 127-130.

DIVENERE, V. J. \& OPDYKE, N. D. 1991b. Magnetic polarity stratigraphy and Carboniferous paleopole positions from the Joggins section, Cumberland structural basin, Nova Scotia. Journal of Geophysical Research: Solid Earth, 96, 4051-4064.

DIVENERE, V. J. \& OPDYKE, N. D. 1990. Paleomagnetism of the Maringouin and Shepody Formations, New Brunswick: A Namurian magnetic stratigraphy. Can. J. Earth Sci. 7, 803-810.

DOH, S. J. \& PIPER, J. D. A. 1994. Palaeomagnetism of the (Upper Palaeozoic-Lower Mesozoic) Pyongan Supergroup, Korea: a Phanerozoic link with the North China Block. Geophysical Journal International, 117, 850-863.

DOELL, R. R. 1956. Remanent magnetization of the Upper-Miocene 'Blue'sandstones of California. Eos, From Lucas, Schneider et al. (eds) The Carboniferous Timescale, Spec. Publ. Geol. Soc. Lond. 
Transactions American Geophysical Union, 372, 156-167.

DOOLEY, R. E. 1983. Paleomagnetism of some mafic intrusions in the South Carolina Piedmont. I. Magnetic systems with single characteristic directions. Physics of the Earth \& Planetary Interiors, 31, 241-268.

DRISCOLL, P.E. \& EVANS, D.A.D., 2016. Frequency of Proterozoic geomagnetic superchrons. Earth and Planetary Science Letters, 437, 9-14.

DUNLOP, D. J. 1979. On the use of Zijderveld vector diagrams in multicomponent paleomagnetic studies. Physics of the Earth \& Planetary Interiors, 20, 12-24.

EBLE, C. F., BLAKE, B. M., GILLESPIE, W. H. \& PFEFFERKORN, H. W. 2009. Appalachian basin fossil floras. In: GREB, S.F. \& CHESNUT JR, D. R. (eds.) Carboniferous of the Appalachian and Black Warrior Basins, Kentucky Geological Survey Special Publication, 10, 46-58.

EDEL, J. B. 1987. Paleopositions of the western Europe Hercynides during the Late Carboniferous deduced from paleomagnetic data: consequences for 'stable Europe'. Tectonophysics, 139, 31-41.

EDEL, J. B. \& SCHNEIDER, J. L. 1995. The Late Carboniferous to Early Triassic geodynamic evolution of Variscan Europe in the light of magnetic overprints in Early Permian rhyolites from the northern Vosges (France) and central Black Forest (Germany. Geophysical Journal International, 122, 858876.

EDEL, J. B. \& WICKERT, F. 1991. Paleopositions of the Saxothuringian (Northern Vosges, Pfalz, Odenwald, Spessart) in Variscan times: paleomagnetic investigation. Earth \& Planetary Science Letters, 103, 10-26.

EDEL, J. B., CASINI, L., OGGIANO, G., ROSSI, P. \& SCHULMANN, K. 2014. Early Permian $90^{\circ}$ clockwise rotation of the Maures-Estérel-Corsica-Sardinia block confirmed by new palaeomagnetic data and followed by a Triassic $60^{\circ}$ clockwise rotation. In: SCHULMANN, K., MARTíNEZ CATALÁN, J. R., LARDEAUX, J. M., JANOUŠEK, V. \& OGGIANO, G. (eds). The Variscan Orogeny: Extent, Timescale and the Formation of the European Crust, Geological Society, London, Special Publications, 405, 333361.

EDEL, J. B., LACAZE, M. \& WESTPHAL, M. 1981. Paleomagnetism in the northeastern Central Massif (France): evidence for Carboniferous rotations of the Hercynian orogenic belt. Earth and Planetary Science Letters, 55, 48-52.

EDEL, J. B., MONTIGNY, R., ROYER, J. Y., THUIZAT, R. \& TROLARD, F. 1986. Paleomagnetic investigations and K-Ar dating on the Variscan plutonic massif of the Champ du Feu and its volcanic-sedimentary environment, northern Vosges, France. Tectonophysics, 122, 165-185.

EDMUNDS, W. E., SKEMA, V. W. \& FLINT, N. K. 1999. Pennsylvanian. In: SHULTZ, C. H. (Ed.) The geology of Pennsylvania, Pennsylvania Geological Survey and Pittsburgh Geological Society, Harrisburg, pp. 148-169. https://shoppaheritage.com/collections/conservation-and-natural-resources

EDMUNDS, W.E. 1996. Correlation chart showing suggested revisions of uppermost Devonian through Permian stratigraphy, Pennsylvania. Pennsylvania Geological Survey, 4th ser., Open-File Report 9649. https://statesurveys.americangeosciences.org/vufind/Record/1985011119

EPSTEIN, J.B., SEVON, W.D. \& GLAESER, J.D. 1974. Geology and mineral resources of the Lehighton and Palmerton Quadrangles, Carbon and Northhampton Counties, Pennsy/vania. Pennsylvania Geological Survey, 4th series. http://maps.denr.pa.gov/publications/Default.aspx?id=189

ERWAN, M., CAMILLE, F., JEAN-LOUIS, P., RAMON, C. \& ANNE-MARIE, L. 2018. Petro-geochemistry and zircon U-Pb dating of the late Variscan Flamanville granodiorite and its Paleoproterozoic basement (Normandy, France). Géologie de la France, 13, 34-48.

ESANG, C. B. \& PIPER, J. D. A. 1984. Palaeomagnetism of the Carboniferous E-W dyke swarm in From Lucas, Schneider et al. (eds) The Carboniferous Timescale, Spec. Publ. Geol. Soc. Lond. 
Argyllshire. Scottish Journal of Geology, 20, 309-314.

ETTENSOHN, F.R. 2009. The Mississippian of the Appalachian Basin. In: Greb, S.F. \& Chesnut Jr. D. R. (Eds.), Carboniferous of the Appalachian and Black Warrior Basins. Kentucky Geological Survey Special Publication, 10, 22-31.

EVANS, D.A., 2006. Proterozoic low orbital obliquity and axial-dipolar geomagnetic field from evaporite palaeolatitudes. Nature, 444, 51-55.

EVERDINGEN, VAN R. O. 1960. Palaeomagnetic analysis of Permian extrusives in the Oslo region, Norway. PhD Thesis Utrecht, In: "Studies on the Igneous Rock Complex of the Oslo Region", Skrifter Norske Vidensk. -Akad. Oslo, Mat. Naturv. kl. 1, 1-80.

EVERITT, C. W. F. 1960. Rock magnetism and the origin of the Midland Basalts. Geophysical Journal International, 32, 203-210.

EVERITT, C. W. F. \& BELSHÉ, J. C. 1960. Palaeomagnetism of the British Carboniferous system. Philosophical Magazine, 5, 675-685.

FITCH, F. J. \& MILLER, J. A. 1964. The age of the paroxysmal Variscan orogeny in England. In: Harland, W. B. GILBERT SMITH A., \& WILCOCK, B. (eds). The Phanerozoic time-scale. Geological Society London, Special Publications, 1, 159-175.

FITCH, F. J., MILLER, J. A. \& WILLIAMS, S. C. 1970. Isotopic ages of British Carboniferous rocks. Compte Rendu de Congrès International de Stratigraphie et de Géologie du Carbonifère, Sheffield, 1967, 2, 771-790.

FACER, R. A. 1976. Palaeomagnetism, radioisotopic age and geochemistry of an Adamellite at Yetholme, NSW. Journal of the Geological Society of Australia, 23, 243-248.

FACER, R. A. 1978. New and recalculated radioisotopic data supporting a Carboniferous age for the emplacement of the Bathurst Batholith, New South Wales. Journal of the Geological Society of Australia, 25, 429-432.

FALCON-LANG, H. J. 2006. Vegetation ecology of Early Pennsylvanian alluvial fan and piedmont environments in southern New Brunswick, Canada. Palaeogeography, Palaeoclimatology, Palaeoecology, 233, 34-50.

FIELDING, C. R., FRANK, T. D., BIRGENHEIER, L. P., RYGEL, M. C., JONES, A. T. \& ROBERTS, J. 2008. Stratigraphic imprint of the Late Palaeozoic Ice Age in eastern Australia: a record of alternating glacial and nonglacial climate regime. Journal of the Geological Society, 165, 129-140.

FILLMORE, D. L., LUCAS, S. G. \& SIMPSON, E. L. 2012. Ichnology of the Mississippian Mauch Chunk Formation, eastern Pennsylvania. Bulletin New Mexico Museum of Natural History \& Science, Albuquerque, 54.

FIORETTI, A. M. \& LANZA, R. 2000. Preliminary Palaeomagnetic Results from the Devono-Carboniferous Admiralty Intrusives (Northern Victoria Land, Antarctica. Terra Antartica, 7, 657-664.

FRANCIS. E. H. 1961. Economic geology of the Fife Coalfields, area II: Cowdenbeath and central Fife. Memoir of the Geological Survey, Scotland.

FULLAGAR, P. D., GOLDBERG, S. A. \& BUTLER, J. R. 1997. Nd and Sr isotopic characterization of crystalline rocks from the southern Appalachian Piedmont and Blue Ridge, North and South Carolina. In: SINHA, A. K., WHALEN, J. B. \& HOGAN, J. P. (eds.), The nature of magmatism in the Appalachian Orogen. Geological Society of America Memoir 191, 165-180.

GAGIEV, M.K.H, KONONOVA, L.I., SHILGINA, V.C. \& KOFOREST E.V. 1991. The boundary of the Devonian and Carboniferous in the Kamenka section (North-East of the USSR). Bulletin of Moscow Society of Naturalists, Geological Series 6, 69-70 (in Russian).

GASQUET D., LETERRIER J., MRINI Z. \& VIDAL P. 1992. Petrogenesis of the Hercynian Tichka plutonic

From Lucas, Schneider et al. (eds) The Carboniferous Timescale, Spec. Publ. Geol. Soc. Lond. 
complex (Western High Atlas, Morocco): trace element and $\mathrm{Rb}-\mathrm{Sr}$ and $\mathrm{Sm}-\mathrm{Nd}$ isotopic constraints. Earth Planet Sci Lett., 108, 29-44

GASTALDO, R. A., PURKYŇOVÁ, E., ŠIMŮNEK, Z. \& SCHMITZ, M. D. 2009 Ecological persistence in the Late Mississippian (Serpukhovian, Namurian A) megafloral record of the Upper Silesian Basin, Czech Republic. Palaios, 24, 336-350

GATLIFF, R.W. 1982. The limestone and dolomite resources of the country around Tidewell, Derbyshire. 1:25000 sheets SK17 and parts of SK18 and 27. Mineral assessment Report, British Geologocal Survey, HMSO. https://webapps.bgs.ac.uk/data/publications/ pubs.cfc?method=viewRecord\&publnld=19864732

GEEVE, R. J., SCHMIDT, P. W. \& ROBERTS, J. 2002. Paleomagnetic results indicate pre-Permian counter-clockwise rotation of the southern Tamworth Belt, southern New England Orogen, Australia. Journal of Geophysical Research: Solid Earth, 107, 2196, doi:10.1029/2000JB000037.

GEORGE, T N, JOHNSON, G A L, MITCHELL, M, PRENTICE, J E, RAMSBOTTOM, W H C, SEVASTOPULO, G D \& WILSON, R B. 1976. A correlation of Dinantian rocks in the British Isles. Geological Society Special Report, No. 7.

GEIKIE, A. 1900. The geology of Central and Western Fife and Kinross-shire. Memoir of the Geological Survey of Scotland, Sheet 41 and parts of 40, 48, 49.

GEUNA, S. E. \& ESCOSTEGUY, L. D. 2004. Palaeomagnetism of the Upper Carboniferous-Lower Permian transition from Paganzo basin, Argentina. Geophysical Journal International, 157, 1071-1089.

GEUNA, S. E., ESCOSTEGUY, L. D. \& MIRÓ, R. 2008. Palaeomagnetism of the Late Devonian-Early Carboniferous Achala Batholith, Córdoba, central Argentina: implications for the apparent polar wander path of Gondwana. Gondwana Research, 132, 227-237.

GIBLING, M. R., CULSHAW, N., PASCUCCI, V., WALDRON, J. W. F. \& RYGEL, M. C. 2019. The Maritimes Basin of Atlantic Canada: Basin Creation and Destruction During the Paleozoic Assembly of Pangea. In: Miall, A. (ed.) The sedimentary basins of the United States and Canada, Elsevier, 267-314.

GILES, P. S. 2008. Windsor Group (Late Mississippian) stratigraphy, Magdalen Islands, Quebec: a rare eastern Canadian record of late Visean basaltic volcanism. Atlantic Geology, 44, 167-185.

GILES, P. S. 2009. Orbital forcing and Mississippian sea level change: time series analysis of marine flooding events in the Visean Windsor Group of eastern Canada and implications for Gondwana glaciation. Bulletin of Canadian Petroleum Geology, 57, 449-471.

GLEN, R. A. \& ROBERTS, J. 2012. Formation of oroclines in the New England Orogen, eastern Australia. Journal of the Virtual Explorer, 43, 1-38.

GROVES, J. R., NEMYROVSKA, T. I. \& ALEKSEEV, A. S. 1999. Correlation of the type Bashkirian Stage (Middle Carboniferous, South Urals) with the Morrowan and Atokan series of the midcontinental and western United States. Journal of Paleontology, 73, 529-539.

GUIRDHAM, C. 1998. Regional stratigraphy, lithofacies, diagenesis and dolomitisation of microbial carbonates in the Lower Carbonifereous, West Lothian Oil-Shale Formation. PhD Thesis, University of East Anglia.

GUIRDHAM, C., ANDREWS, J. E., BROWNE, M. A. E. \& DEAN, M. T. 2003. Stratigraphic and palaeoenvironmental significance of microbial carbonates in the Asbian Sandy Craig Formation of Fife. Scottish Journal of Geology, 392, 151-168.

GUTTERIDGE, P. 1989. Controls on carbonate sedimentation in a Brigantian intrashelf basin (Derbyshire). In: ARTHURTON, R.S. GUTTERIDGE, P. NOLAN, S.C (Eds.) The role of tectonics in Devonian and Carboniferous sedimentation in the British Isles. Occasional Publication of the Yorks. Geol. Soc. 6, 171-187.

From Lucas, Schneider et al. (eds) The Carboniferous Timescale, Spec. Publ. Geol. Soc. Lond. 
GUZHIKOV , Yu. 2019. General magnetostratigraphic scale: present status and outlook of development. In: NURGALIEV, D. NURGALIEV, D., SHCHERBAKOV, V., KOSTEROV, A. \& SPASSOV, S. (eds), Recent advances in rock magnetism, environmental magnetism \& paleomagnetism, Springer, 343-351.

HALVORSEN, E., LEWANDOWSKI, M. \& JELEŃSKA, M. 1989. Palaeomagnetism of the Upper Carboniferous Strzegom and Karkonosze granites and the Kudowa granitoid from the Sudet Mountains, Poland. Physics of the Earth \& Planetary Interiors, 55, 54-64.

HANEDA, Y., OKADA, M., SUGANUMA, Y. \& KITAMURA, T., 2020. A full sequence of the MatuyamaBrunhes geomagnetic reversal in the Chiba composite section, Central Japan. Progress in Earth and Planetary Science, 7, 1-22.

HARTZ, E. H., TORSVIK, T. H. \& ANDRESEN, A. 1997. Carboniferous age for the East Greenland 'Devonian' basin: Paleomagnetic and isotopic constraints on age, stratigraphy, and plate reconstructions. Geology, 25, 675-678.

HARWOOD, M. 2005. The facies architecture and depositional geometry of a Late Visean carbonate platform margin, Derbyshire, UK. Unpubl. PhD, Cardiff Univ.

HASLETT, J. \& PARNELL, A., 2008. A simple monotone process with application to radiocarbon-dated depth chronologies. Royal Statistical Society Journal, Series C, 57, 399-418.

HENDERSON, R. A. DAVIS B. K. \& FANNING, C. M. 1998. Stratigraphy, age relationships and tectonic setting of rift-phase infill in the Drummond Basin, central Queensland. Australian Journal of Earth Sciences, 45, 579-595.

HENRY, B., MERABET, N., YELLES, A., DERDER, M. M. \& DALY, L. 1992. Geodynamical implications of a Moscovian palaeomagnetic pole from the stable Saharan craton (Illizi basin, Algeria). Tectonophysics, 201, 83-96.

HERBIG, H-G. 2016. Mississippian (Early Carboniferous) sequence stratigraphy of the Rhenish Kulm Basin, Germany. Geologica Belgica, 19, 81-110.

HOROWITZ, A. S. \& REXROAD, C. B. 1972. Conodont biostratigraphy of some United States Mississippian sites. Journal of Paleontology, 46, 884-891.

HOUNSLOW, M. W. 2016. Geomagnetic reversal rates following Palaeozoic superchrons have a fast restart mechanism. Nature communications, 7, 12507, doi.org/10.1038/ncomms 12507

HOUNSLOW, M. W. \& BALABANOV, Y. P. 2018. A geomagnetic polarity timescale for the Permian, calibrated to stage boundaries. In: Lucas, S. G. \& Shen, S. Z. (Eds.). The Permian timescale. Geological Society, London, Special Publications, 450, 61-103.

HOUNSLOW, M. W., DOMEIER, M. \& BIGGIN, A. J. 2018. Subduction flux modulates the geomagnetic polarity reversal rate. Tectonophysics, 742, 34-49.

HOWELL, L. G. \& MARTINEZ, J. D., 1957, Polar movement as indicated by rock magnetism: Geophysics, 22, 384-397.

HU, K. Y., QI, Y. P., WANG, Q. L., NEMYROVSKA, T. I. \& CHEN, J. T. 2017. Early Pennsylvanian conodonts from the Luokun section of Luodian, Guizhou, South China. Palaeoworld, 26, 64-82.

HUANG, K. \& OPDYKE, N. D. 1991. Paleomagnetic results from the Upper Carboniferous of the ShanThai-Malay block of western Yunnan, China. Tectonophysics, 192, 333-344.

HUANG, B., OTOFUJI, Y. I., ZHU, R., SHI, R. \& WANG, Y. 2001. Paleomagnetism of Carboniferous sediments in the Hexi corridor: its origin and tectonic implications. Earth \& Planetary Science Letters, 194, 135-149.

IOSIFIDI, A. G., MIKHAILOVA, V. A., POPOV, V. V., SERGIENKO, E. S., DANILOVA, A. V., OTMAS, N. M. \& ZHURAVLEV, A. V. 2019. Carboniferous of the Russian platform: paleomagnetic data. In: NURGALIEV, D., SHCHERBAKOV, V., KOSTEROV, A. \& SPASSOV, S. (Eds.). Recent advances in rock 
magnetism, environmental magnetism \& paleomagnetism. Springer, 37-54.

IOSIFIDI, A. G. \& KHRAMOV, A. N. 2013. Paleomagnetism of Devonian and Carboniferous sedimentary rocks of Spitsbergen: to the Paleozoic history of the Barents-Kara basin framing. Izvestiya, Physics of the Solid Earth, 49, 725-742.

IOSIFIDI, A. G. \& MIKHAILOVA, V. A. 2017. Paleomagnetism of Carboniferous formations of the Russian platform: Reinvestigation of old collections. Izvestiya, Physics of the Solid Earth, 53, 461-476.

IOSIFIDI, A. G., MIKHAILOVA, V. A., POPOV, V. V., SERGIENKO, E. S., DANILOVA, A. V. \& OTMAS, N. M. 2018. The Carboniferous of the Moscow syneclise: Paleomagnetic data. Izvestiya, Physics of the Solid Earth, 54, 163-177.

IDNURM, M., KLOOTWIJK, C., THÉVENIAUT, H. \& TRENCH, A. 1996. Magnetostratigraphy. In: YOUNG, G.C. \& LAURIE, J.R. (eds.) An Australian Phanerozoic timescale. Oxford University Press, 22-51.

IRVING E. \& GREEN, R. 1958, Polar movement relative to Australia: Royal Astron. Soc. Geophys. Jour., 1, 64-72.

IRVING, E. 1957, Directions of magnetization in the Carboniferous glacial varves of Australia, Nature, 180, 280-281.

IRVING, E. 1959. Palaeomagnetic pole positions: A survey and analysis: Royal Astron. Soc. Geophys. Jour., 2, 51-79.

IRVING, E. \& PARRY, L. G., 1963. The magnetism of some Permian rocks from New South Wales. Geophys. Journal Roy. Astro. Soc., London, 7, 395-411.

IRVING, E., ROBERTSON, W. A., STOTT, P. M., TARLING, D. H. \& WARD, M. A. 1961. Treatment of partially stable sedimentary rocks showing planar distribution of directions of magnetization. Journal of Geophysical Research, 66, 1927-1933.

IRVING, E. \& PULLAIAH, G. 1976. Reversals of the geomagnetic field, magnetostratigraphy, and relative magnitude of paleosecular variation in the Phanerozoic. Earth-Science Reviews, 12, 35-64.

ITANO, W. M., HOUCK, K. J. \& LOCKLEY, M. G. 2003. Ctenacanthus and other chondrichthyan spines and denticles from the Minturn Formation (Pennsylvanian) of Colorado. Journal of Paleontology, 77, 524-535.

JENKINS, T. B. H., CRANE, D. T. \& MORY, A. J. 1993. Conodont biostratigraphy of the Visean Series in eastern Australia. Alcheringa, 17, 211-283.

JENNINGS, J. R. 1985. Fossil plants from the Mauch Chunk Formation of Pennsylvania: morphology of Adiantites antiquus. Journal of Paleontology, 59, 1146-1157.

JIRÁSEK, J., OPLUŠTIL, S., SIVEK, M., SCHMITZ, M. D. \& ABELS, H. A. 2018. Astronomical forcing of Carboniferous paralic sedimentary cycles in the Upper Silesian Basin, Czech Republic (Serpukhovian, latest Mississippian): New radioisotopic ages afford an astronomical age model for European biozonations and substages. Earth-Science Reviews, 177, 715-741.

JOHNSON, S. A., GLOVER, B. W. \& TURNER, P. 1997. Multiphase reddening and weathering events in Upper Carboniferous red beds from the English West Midlands. Journal of the Geological Society, 154, 735-745.

JOHNSON, S. A., TURNER, P., HARTLEY, A. \& REY, D. 1995. Palaeomagnetic implications for the timing of hematite precipitation and remagnetization in the Carboniferous Barren Red Measures, UK southern North Sea. In: TURNER, P. \& TURNER, A. (eds.) Palaeomagnetic applications in hydrocarbon exploration and production. Geological Society, London, Special Publications, 98, 97117.

JUTRAS, P., DOSTAL, J., KAMO, S. \& MATHESON, Z. 2018. Tectonostratigraphic and petrogenetic setting of late Mississippian volcanism in eastern Canada. Canadian Journal of Earth Sciences, 55, 356-372.

From Lucas, Schneider et al. (eds) The Carboniferous Timescale, Spec. Publ. Geol. Soc. Lond. 
JUTRAS, P., MCLEOD, J. R. \& UTTING, J. 2015. Sedimentology of the lower Serpukhovian (upper Mississippian) Mabou Group in the Cumberland Basin of eastern Canada: tectonic, halokinetic, and climatic implications. Canadian Journal of Earth Sciences, 52, 1150-1168.

JUTRAS, P., MCLEOD, J., MACRAE, R. A. \& UTTING, J. 2016. Complex interplay of faulting, glacioeustatic variations and halokinesis during deposition of upper Visean units over thick salt in the western Cumberland Basin of Atlantic Canada. Basin Research, 28, 483-506.

KAMMER, T. W. \& LAKE, A. M. 2001. Salinity ranges of Late Mississippian invertebrates of the central Appalachian Basin. Southeastern Geology, 40, 99-116.

KAMMER, T. W. \& SPRINGER, G. S. 2008. Biostratigraphy of crinoids from the Wymps Gap Member of the Greenbrier Formation (Mississippian, Chesterian) in northern West Virginia. Journal of Paleontology, 82, 1182-1189.

KARBUB, A. M. 1993. Foraminiferal biostratigraphy and microfacies of the Lower Carboniferous rocks, Central Scotland. Unpubl. MPhil, Univ. Edinburgh.

KENT, D. V. 1982. Paleomagnetic evidence for post-Devonian displacement of the Avalon Platform (Newfoundland). Journal of Geophysical Research: Solid Earth, 87, 8709-8716.

KENTER, J. A. M., HARRIS, P. M.. COLLINS, J. F., WEBER, L. J., KUANYSHEVA, G. \& FISCHER, D. J. 2006, Late Visean to Bashkirian platform cyclicity in the central Tengiz buildup, Precaspian Basin, Kazakhstan: Depositional evolution and reservoir development. In: HARRIS, P. M. \& WEBER, L. J. (eds), Giant hydrocarbon reservoirs of the world: From rocks to reservoir characterization and modeling: AAPG Memoir 88/SEPM Special Publication, 7- 54.

KHRAMOV, A.N., 1963. Paleomagnetism of the Paleozoic. Transactions of VNIGRI (in Russian).

KHRAMOV, A.N. 1967. The earth's magnetic field in the late Paleozoic. Izv. Akad. Nauk SSSR, Fiz. Zemli, 1, 86-108 (in Russian).

KHRAMOV, A.N. 1987. Paleomagnetology. Springer Verlag, Berlin.

KHRAMOV, A.N. \& RODIONOV, V.P. 1980. The geomagnetic field during Palaeozoic time. Journal of geomagnetism \& Geoelectricity, 32 (Supplement 3), 99-115.

KHRAMOV, A.N. \& DAVYDOV, V.I. 1984. Paleomagnetism of Upper Carboniferous and Lower Permian in the south of the U.S.S.R. and the problems of the structure of the Kiama hyperzone. Transactions of VNIGRI, 55-73 (in Russian).

KHRAMOV A.N. \& SHKATOVA, V. K. 2000. The general magnetostratigraphic scale of the polarity of Phanerozoic Eon. In: Karpinsky, A. P. (ed.) Supplement to the Stratigraphic Code of Russia, Russian Geological Research Institute, St Petersburg, 34-45 (in Russian).

KHRAMOV, A.N., GONCHAROV, G.I., KOMISSSAROVA, R.A., OSIPOVA, E.P., POGARSKAYA, I.A., RODIONOV, V.P., STAUTSILAIS, I.P., SMIRNOV, L.S. \& FORSH, N.N. 1974. Paleozoic Paleomagnetism. Transactions of VNIGRI, Nedra, Leningrad, 1-238 (In Russian).

KIM, K.H., LEE, J.D. \& CHOI, M.O. 1992. Carboniferous-Triassic paleomagnetism of South Korea. Journal of Geomagnetism \& Geoelectricity, 44, 959-978.

KIRTON, S.R. 1984. Carboniferous volcanicity in England with special reference to the Westphalian of the $\mathrm{E}$ and W Midlands. Journal of the Geological Society, 141, 161-170.

KLOOTWIJK, C.T. 2016. Paleomagnetism of the Carboniferous Rouchel Block, Tamworth Belt, and pole path revision for the New England Orogen, eastern Australia. Australian Journal of Earth Sciences, 63, 513-549.

KLOOTWIJK, C. T. 2019. Paleomagnetism of the Carboniferous Gresford Block, Tamworth Belt, southern New England Orogen: minor counter-clockwise rotation of a primary arc segment. Australian Journal of Earth Sciences, doi.org/10.1080/08120099.2020.1674381

From Lucas, Schneider et al. (eds) The Carboniferous Timescale, Spec. Publ. Geol. Soc. Lond. 
KLOOTWIJK, C. \& GIDDINGS, J. 1993. Palaeomagnetic results of Upper Palaeozoic volcanics, northeastern Queensland, and Australia's Late Palaeozoic APWP. In : FLOOD, P.G \& AITCHISON, J.C (eds). New England Orogen, Eastern Australia, Symposium, Univ New England, Armidale 2-4 Feb 1993, 617-627.

KLOOTWIJK, C.T. 2002, Carboniferous palaeomagnetism of the Rocky Creek Block, northern Tamworth Belt, and the New England pole path. Australian Journal of Earth Sciences, 50, 131-135.

KLOOTWIJK, C.T., 2003, Carboniferous palaeomagnetism of the Werrie Block, northern Tamworth Belt, and the New England pole path. Australian Journal of Earth Sciences, 50, 865-902.

KODAMA, K. P. 2009. Simplification of the anisotropy-based inclination correction technique for magnetite-and haematite-bearing rocks: a case study for the Carboniferous Glenshaw and Mauch Chunk Formations, North America. Geophysical Journal International, 176, 467-477.

KODAMA, K. P. 2019. Rock Magnetic Cyclostratigraphy of the Carboniferous Mauch Chunk Formation, Pottsville, PA, United States. Frontiers in Earth Science, 7, 285, doi: 10.3389/feart.2019.00285.

KOLESOV, E.V. 1984, Paleomagnetic stratigraphy of the Devonian-Carboniferous boundary beds in the Soviet North-East and in the Franco-Belgian Basin. Annales Société Geoloque de Belgique, 107, 135136.

KOLESOV, E.V. 2007. A Palaeozoic magnetostratigraphic scale for North-East Russia and a trans-regional correlation of its reference magnetozones. Bulletin of the North-East Scientific Center, Russian Academy of Sciences, Far East Branch, 4, 31-42 (in Russian). https: //elibrary.ru/ contents.asp?id=33174698

KOLESOV, E.V.2005. Magnetostratigraphy of the Paleozoic of the north-east Russia. DPhil Thesis, NorthEastern Research Institute of the Far-Eastern Branch, Russian Academy of Sciences, Saratov (in Russian). http://www2.neisri.ru/index.php/ru/

KORSCH, R. J., TOTTERDELL, J. M., CATHRO, D. L. \& NICOLL, M. G. 2009. Early Permian east Australian rift system. Australian Journal of Earth Sciences, 56, 381-400.

KRYZA, R., SCHALTEGGER, U., OBERC-DZIEDZIC, T., PIN, C. \& OVTCHAROVA, M. 2014. Geochronology of a composite granitoid pluton: a high-precision ID-TIMS U-Pb zircon study of the Variscan Karkonosze Granite (SW Poland). International Journal of Earth Sciences, 103, 683-696.

KULAGINA, E.I., PAZUKHIN, V.N., DAVYDOV, V.I., 2009. Pennsylvanian biostratigraphy of the Basu River section with emphasis on the Bashkirian-Moscovian transition. Proceedings of the International Field Meeting, Ufa-Sibai, 13-18 August 2009, 34-41. http://ig.ufaras.ru/File/PubTxt/ CARBON_2009/01_05_09.pdf

KULESHOV, V. N., SEDAEVA, K. M., GOROZHANIN, V. M. \& GOROZHANINA, E. N. 2018. Hypostratotype of the Bashkirian Stage of the Carboniferous System (Askyn River, Bashkortostan): lithology, isotopes $\left(\delta^{13} \mathrm{C}, \delta^{18} \mathrm{O}\right)$, and carbonate depositional settings. Stratigraphy \& Geological Correlation, 26, 698719.

LANGEREIS, C.G., KRIJGSMAN, W., MUTTONI, G. AND MENNING, M., 2010. Magnetostratigraphyconcepts, definitions, and applications. Newsletters on Stratigraphy, 43, 207-233.

LARSON, E. E., WALKER, T. R., PATTERSON, P. E., HOBLITT, R. P. \& ROSENBAUM, J. G. 1982. Paleomagnetism of the Moenkopi Formation, Colorado Plateau: Basis for long-term model of acquisition of chemical remanent magnetism in red beds. Journal of Geophysical Research, Solid Earth, 87, 1081-1106.

LEE, C. Z. 2010. The stratigraphy of the Pyeongan Supergroup of South Korea: A review. Journal of the Korean Earth Science Society, 31, 419-429.

LEE, Y. S., NISHIMURA, S. \& MIN, K. D. 1996. High-unblocking-temperature haematite magnetizations of From Lucas, Schneider et al. (eds) The Carboniferous Timescale, Spec. Publ. Geol. Soc. Lond. 
Late Palaeozoic red beds from the Okcheon zone, southern part of the Korean Peninsula. Geophysical Journal International, 125, 266-284.

LEVINE, J.R. \& SLINGERLAND, R. 1987. Upper Mississippian to Middle Pennsylvanian stratigraphic section, Pottsville, Pennsylvania. In: ROY, D.C. (ed.), Geological Society of America, Centennial Field Guide 5, Northeast Section of the Geological Society of America, 59-63.

LISS, D., OWENS, W. H. \& HUTTON, D. H. W. 2004. New palaeomagnetic results from the Whin Sill complex: evidence for a multiple intrusion event and revised virtual geomagnetic poles for the late Carboniferous for the British Isles. Journal of the Geological Society, 161, 927-938.

LIU, H., BAI, Z., WANG, H. \& YASKAWA, K. 1991. Search for the geomagnetic reversal near the DevonianCarboniferous boundary. Journal of Geomagnetism \& Geoelectricity, 43, 755-764.

LIU, Y. Q., JI, Q., KUANG, H. W., JIANG, X. J., XU, H. \& PENG, N. 2012. U-Pb zircon age, sedimentary facies, and sequence stratigraphy of the Devonian-Carboniferous boundary, Daposhang Section, Guizhou, China. Palaeoworld, 21, 100-107.

MAGNUS, G. \& OPDYKE, N. D. 1991. A paleomagnetic investigation of the Minturn Formation, Colorado: a study in establishing the timing of remanence acquisition. Tectonophysics, 187, 181-189.

MAPLES, C. G. \& WATERS, J. A. 1987. Redefinition of the Meramecian/Chesterian boundary (Mississippian). Geology, 15, 647-651.

MAMET, B. L. 1970. Carbonate microfacies of the Windsor Group (Carboniferous), Nova Scotia and New Brunswick. Geological Survey of Canada, Paper 70-21.

MANZONI, M., VENTURINI, C. \& VIGLIOTTI, L. 1989. Paleomagnetism of upper Carboniferous limestones from the Carnic Alps. Tectonophysics, 165, 73-80.

MARTIN, D. L., NAIRN, A. E. M., NOLTIMIER, H. C., PETTY, M. H. \& SCHMITT, T. J. 1978. Paleozoic and Mesozoic paleomagnetic results from Morocco. Tectonophysics, 44, 91-114.

MARTINEZ, J. D. \& HOWELL, L. G. 1956. Palaeomagnetism of chemical sediments. Nature, 178, 204-205.

MCCABE, C. \& CHANNEL, J.E.T. 1994. Late Palaeozoic remagnetisation during in limestones of the Craven Basin (Northern England) and rock magnetic fingerprinting of remagnetised carbonates. $J$. Geophys. Res., 99, 4603-4612.

MCCABE, C. \& ELMORE, R.D. 1989. The occurrence and origin of late Paleozoic remagnetisation in the sedimentary rocks of North America. Reviews in Geophysics, 27, 471-494.

MCELHINNY, M. W. 1966. An improved method for demagnetizing rocks in alternating magnetic fields. Geophysical Journal International, 10, 369-374.

MCELHINNEY, M. W. 1973. Palaeomagnetism and Plate Tectonics. Cambridge University Press, Cambridge.

MCELHINNEY, M. W. \& MCFADDEN, P. 2000. Paleomagnetism, Continents and Oceans, 2nd Edition, Academic Press

MCELHINNY, M. W. \& LOCK, J. 1996. IAGA paleomagnetic databases with Access. Surveys in Geophysics, 17, 575-591.

MCLEAN, D., OWENS, B., BODMAN, D. J. \& MCLEAN, F. D. 2018. Miospores from the Brigantian stratotype section at Janny Wood, Cumbria. Proceedings of the Yorkshire Geological Society, 62, 89100.

MCPHIE, J. 1984. Permo-Carboniferous silicic volcanism and palaeogeography on the western edge of the New England Orogen, north-eastern New South Wales. Australian Journal of Earth Sciences, 31, 133-146.

MERRILL, R. T. 1985. Correlating magnetic field polarity changes with geologic phenomena. Geology, 13, 487-490.

From Lucas, Schneider et al. (eds) The Carboniferous Timescale, Spec. Publ. Geol. Soc. Lond. 
MITCHELL, M. 1989. Biostratigraphy of Visean (Dinantian) rugose coral faunas from Britain. Proceedings of the Yorkshire Geological Society, 47, 233-247.

MIKULSKI, S.Z., WILLIAMS, I.S. \& BAGIŃSKI, B. 2013. Early Carboniferous (Visean ) emplacement of the collisional Kłodzko-Złoty Stok granitoids (Sudetes, SW Poland): constraints from geochemical data and zircon U-Pb ages. International Journal of Earth Sciences, 102, 1007-1027.

MILLER, K. G. \& WRIGHT, J. D. 2017. Success and failure in Cenozoic global correlations using golden spikes: A geochemical and magnetostratigraphic perspective. Episodes, 40, 8-21.

MOBLEY, R. M., YOGODZINSKI, G. M., CREASER, R. A. \& BERRY, J. M. 2014. Geologic history and timing of mineralization at the Haile gold mine, South Carolina. Economic Geology, 109, 1863-1881.

MOLOSTOVSKY, E. A. PECHERSKY, D. M. \& FROLOV, I. Yu. 2007. Magnetostratigraphic Timescale of the Phanerozoic and Its Description Using a Cumulative Distribution Function. Izvestiya, Phys. Solid Earth 43, 811-818.

MONAGHAN, A. A. \& BROWNE, M. A. 2010. Nine ${ }^{40} \mathrm{Ar} /{ }^{39} \mathrm{Ar}$ dates from Carboniferous igneous rocks of the midland valley of Scotland, Open report OR/10/065, British Geol. Survey.

MONAGHAN, A. A., BROWNE, M. A. \& BARFOD, D. N. 2014. An improved chronology for the Arthur's Seat volcano and Carboniferous magmatism of the Midland Valley of Scotland. Scottish Journal of Geology, 50, 165-172.

MORRIS, P. 1971. Two component magnetisation in Irish Carboniferous limestone. Earth \& Planetary Science Letters, 12, 350-354.

MORY, A. 1980. A review of Early Carboniferous stratigraphy and correlations in the northern Tamworth Belt, New South Wales. Proc. Linn. Soc. New South Wales,105, 213-236.

MORY, A. J. \& CRANE, D. T. 1982. Early Carboniferous Siphonodella (conodonta) faunas from eastern Australia. Alcheringa, 6, 275-303.

MURTHY, G. S. 1985. Paleomagnetism of certain constituents of the Bay St. George sub-basin, western Newfoundland. Physics of the Earth \& Planetary Interiors, 392, 89-107.

NAWROCKI, J., FANNING, M., LEWANDOWSKA, A., POLECHOŃSKA, O. \& WERNER, T. 2008. Palaeomagnetism and the age of the Cracow volcanic rocks (S. Poland). Geophysical Journal International, 174, 475-488.

NEMIROVSKAYA T.I. \& ALEKSEEV, A.S. 1994. The Bashkirian conodonts of the Askyn section, Bashkirian Mountains, Russia. Bulletin de la Societe belge de Geologie, 103, 109-133.

NICK, K., XIA, K.D., ELMORE, R.D. 1991. Paleomagnetic and petrographic evidence for early magnetisations in successive terra rosa palaeosols, Lower Pennsylvanian Black Prince Limestone, Arizona. J. Geophys. Res., 96, 9873-9885.

NOZHAROV, P., PETKOV, N., YANEV, S., KROPÁČEK, V., KRS, M., PRUNER, P. \& PÍCHA, J. 1980. A palaeomagnetic and petromagnetic study of Upper-Carboniferous, Permian and Triassic sediments, NW Bulgaria. Studia Geophysica et Geodaetica, 24, 252-284.

OPDYKE, N.D. \& CHANNELL, J.E.T. 1996. Magnetic stratigraphy. London \& San Diego Academic Press.

OPDYKE, N. D. 1995. Magnetostratigraphy of Permo-Carboniferous time. In: BERGGREN, W.A., KENT; D.V. AUBRY, M-P. \& HARDENBOL, J. (eds.) Geochronology time scales \& global stratigraphic correlation, SEPM Special Publication, 54, 41-47.

OPDYKE, N. D., ROBERTS, J., CLAOUÉ-LONG, J., IRVING, E. \& JONES, P. J. 2000. Base of the Kiaman: Its definition and global stratigraphic significance. Geological Society of America Bulletin, 112, 13151341.

OPDYKE, N. D. \& DIVENERE, V. J. 2004. The magnetic polarity stratigraphy of the Mauch Chunk Formation, Pennsylvania. Proceedings of the National Academy of Sciences, 101, 13423-13427.

From Lucas, Schneider et al. (eds) The Carboniferous Timescale, Spec. Publ. Geol. Soc. Lond. 
OPDYKE, N. D., GILES, P. S. \& UTTING, J. 2014. Magnetic polarity stratigraphy and palynostratigraphy of the Mississippian-Pennsylvanian boundary interval in eastern North America and the age of the beginning of the Kiaman. Geological Society of America Bulletin, 126, 1068-1083.

OPPENHEIM, M.J., PIPER, J.D.A. \& ROLPH, T.C. 1994. A palaeointensity study of the Lower Carboniferous transitional geomagnetic field directions: the Cockermouth lavas, northern England. Phys. Earth \& Planet. Inter., 82, 65-74.

OVERSBY, B. \& MCKENZIE, D. 1994. Geology of late Palaeozoic ignimbrites in the Georgetown region, northeastern Queensland. Australian Geol. Survey AFSO record 1994/20. Australian Govt. Publishing, Canberra. https://ecat.ga.gov.au/geonetwork/srv/api/records/a05f7892-7445-7506e044-00144fdd4fa6

OWENS, B., MCLEAN, D., SIMPSON, K. R.M., SHELL, P. M.J. \& ROBINSON, R. 2005. Reappraisal of the Mississippian palynostratigraphy of the east Fife coast, Scotland, United Kingdom. Palynology, 29, 23-47.

PALMER, J.A., 1987. Carboniferous magnetostratigraphy, Unpubl. PhD. Newcastle upon Tyne.

PALMER, J.A., PERRY, S.P.G. \& TARLING, D.H., 1985, Carboniferous magnetostratigraphy. Journal of Geological Society London, 142, 945-955.

PAN, H. \& SYMONS, D. T. A. 1993. The Pictou red beds' Pennsylvanian pole: Could Phanerozoic rocks in the interior United States be remagnetized?. Journal of Geophysical Research: Solid Earth, 98, 6227-6235.

PAPROTH, E., DUSAR, M., BLESS, M. J., BOUCKAERT, J., DELMER, A., FAIRON-DEMARET, M., HOULLEBERGHS, E., LALOUX, M., PIERART, P., SOMERS, Y. M., STREEL, M., THOREZ, J. \& TRICOT, J. 1983. Bio-and lithostratigraphic subdivisions of the Silesian in Belgium, a review. Annales de la Société géologique de Belgique, 106, 241-283.

PAQUETTE, J. L., MÉNOT, R. P., PIN, C. \& ORSINI, J. B. 2003. Episodic and short-lived granitic pulses in a post-collisional setting: evidence from precise $\mathrm{U}-\mathrm{Pb}$ zircon dating through a crustal cross-section in Corsica. Chemical Geology, 198, 1-20.

PARK, A. F. \& HINDS, S. J. 2019. Post-Devonian movement on the Fredericton Fault and tectonic activity in the New Brunswick Platform, central New Brunswick, Canada. Atlantic Geology: Journal of the Atlantic Geoscience Society, 55, 213-241.

PARNELL, A. C., HASLETT, J., ALLEN, J. R., BUCK, C. E. \& HUNTLEY, B. 2008. A flexible approach to assessing synchroneity of past events using Bayesian reconstructions of sedimentation history. Quaternary Science Reviews, 27, 1872-1885.

PAVLOV, V. \& GALLET, Y. 2005. A third superchron during the Early Paleozoic. Episodes, 28, 78-84.

PECHERSKY, D. M., LYUBUSHIN, A. A. \& SHARONOVA, Z. V. 2010. On the Synchronism in the Events within the Core and on the Surface of the Earth: the Changes in the Organic World and in the Polarity of the Geomagnetic Field in the Phanerozoic. Izvestiya, Physics of the Solid Earth, 46, 613623.

PERRY, S. P. G. 1979. Palaeomagnetic studies of British carbonate sediments. Unpubl. PhD thesis, Univ. Newcastle upon Tyne.

PHILLIPS, G., ROBINSON, J., GLEN, R. \& ROBERTS, J. 2016. Structural inversion of the Tamworth Belt: Insights into the development of orogenic curvature in the southern New England Orogen, Australia. Journal of Structural Geology, 86, 224-240.

PIPER, J. D. A., ATKINSON, D., NORRIS, S. \& THOMAS, S. 1991. Palaeomagnetic study of the Derbyshire lavas and intrusions, central England: definition of Carboniferous apparent polar wander. Physics of the Earth \& Planetary Interiors, 69, 37-55.

From Lucas, Schneider et al. (eds) The Carboniferous Timescale, Spec. Publ. Geol. Soc. Lond. 
PISAREVSKY, S. A., ROSENBAUM, G., SHAANAN, U., HOY, D., SPERANZA, F. \& MOCHALES, T. 2016. Paleomagnetic and geochronological study of Carboniferous forearc basin rocks in the southern New England Orogen (eastern Australia). Tectonophysics, 681, 263-277.

POINTON, M. A., CHEW, D. M., OVTCHAROVA, M., SEVASTOPULO, G. D. \& CROWLEY, Q. G. 2012. New high-precision $\mathrm{U}-\mathrm{Pb}$ dates from western European Carboniferous tuffs; implications for time scale calibration, the periodicity of late Carboniferous cycles and stratigraphical correlation. Journal of the Geological Society, 169, 713-721

POINTON, M. A., CHEW, D. M., OVTCHAROVA, M., SEVASTOPULO, G. D. \& DELCAMBRE, B. 2014. Highprecision $\mathrm{U}-\mathrm{Pb}$ zircon CA-ID-TIMS dates from western European late Visean bentonites. Journal of the Geological Society, 171, 649-658.

POTY, E., ARETZ, M. \& HANCE, L. 2014. Belgian substages as a basis for an international chronostratigraphic division of the Tournaisian and Visean . Geological Magazine, 151, 229-243.

POTY, E., DEVUYST, F. X. \& HANCE, L. 2006. Upper Devonian and Mississippian foraminiferal and rugose coral zonations of Belgium and northern France: a tool for Eurasian correlations. Geological Magazine, 143, 829-857.

RATCLIFFE, K., URBAT, M., EMMA, D. PLAYTON, T. \& KATZ, D. 2013. Using chemo and magnetostratigraphy to define a chronostratigraphic framework in an isolated carbonate platform: the Tengiz Field, Republic of Kazakhstan. AAPG abstract, May 19-22.

http://www.searchanddiscovery.com/abstracts/html/2013/90163ace/abstracts/rat.htm

READ, C. B. 1955. Floras of the Pocono formation and Price sandstone in parts of Pennsy/vania, Maryland, West Virginia, and Virginia. Geological Survey Prof. Paper 263, United States Government Printing Office, Washington. https://pubs.usgs.gov/pp/0263/report.pdf

READ, C.B. \& MAMAY, S. H. 1964. Upper Paleozoic floral zones and floral provinces of the United States. United States Geological Survey Professional Paper 454K. https://pubs.usgs.gov/pp/0454k/report.pdf

REPETSKI J.E. \& STAMM, R. 2009. Mississippian Conodonts of the Appalachian Basin. In: GREB, S.F. \& CHESNUT Jr., D. R. (eds). Carboniferous of the Appalachian and Black Warrior Basins. Kentucky Geological Survey Special Publication, 10, 59-61.

REX, G. M. \& SCOTT, A. C. 1987. The sedimentology, palaeoecology and preservation of the Lower Carboniferous plant deposits at Pettycur, Fife, Scotland. Geological Magazine, 124, 43-66.

RICHARDS, B. C. 2013. Current status of the international Carboniferous time scale. In: Lucas, S.G., DiMichele, W.A., Barrick, J.E., Schneider, J.W., Spielmann, J.A. (eds). The Carboniferous-Permian Transition. New Mexico Museum of Natural History \& Science, Bulletin 60, 348-353.

ROBERTS, J. 1975. Early Carboniferous brachiopod zones of eastern Australia. Journal of the Geological Society of Australia, 22, 1-31.

ROBERTS, J., JONES, P. J. \& JENKINS, T. B. H. 1993. Revised correlations for Carboniferous marine invertebrate zones of eastern Australia. Alcheringa, 17, 353-376.

ROBERTS, J., CLAOUÉ-LONG, J.C., JONES, P.J. \& FOSTER, C.B., 1995. SHRIMP zircon age control of Gondwanan sequences in Late Carboniferous Australia. In: DUNAY, R. \& HAILWOOD, E. (eds), Nonbiostratigraphical methods of dating and correlation. Geological Society of London Special Publication 89, 145-174.

ROBERTS , J., WANG X.\& FANNING, M. 2003a. Stratigraphy and correlation of Carboniferous ignimbrites, Rocky Creek region, Tamworth Belt, Southern New England Orogen, New South Wales. Australian Journal of Earth Sciences, 50, 931-954.

ROBERTS , J. OFFLER R. \& FANNING, M. 2006 Carboniferous to Lower Permian stratigraphy of the From Lucas, Schneider et al. (eds) The Carboniferous Timescale, Spec. Publ. Geol. Soc. Lond. 
southern Tamworth Belt, southern New England Orogen, Australia: Boundary sequences of the Werrie and Rouchel blocks. Australian Journal of Earth Sciences, 53, 249-284.

ROBERTS J. \& JAMES, L. 2010 Stratigraphic relationships of Carboniferous volcanogenic successions in the Clifton-Carroll block and Werrie Syncline, northern Tamworth Belt, southern New England Orogen. Australian Journal of Earth Sciences, 57, 193-205.

ROBERTS, R. J., TORSVIK, T. H., ANDERSEN, T. B. \& REHNSTROM, E. F. 2003b. The Early Carboniferous Magerøy dykes, northern Norway: palaeomagnetism and palaeogeography. Geological Magazine, 140, 443-451.

ROLF, C. \& HENJES-KUNST, F. 2003. Palaeomagnetic Investigations on Palaeozoic and Mesozoic Igneous and Metasedimentary Rocks from Northern Victoria Land, Antarctica. Terra Antartica, 10, 157-170.

ROTHER, K. \& STORETVEDT, K. M. 1991. Polyphase magnetization in Lower Carboniferous rocks of S. Scotland: palaeomagnetic and tectonic considerations. Physics of the Earth \& Planetary Interiors, 67, 251-267.

ROY, J.L., 1969. Paleomagnetism of the Cumberland Group and other Paleozoic formations. Can. J. Earth Sci., 6, 663-669.

ROY, J.L. \& PARK, J.K., 1969. Paleomagnetism of the Hopewell Group, New Brunswick. J. Geophys. Res., 74, 594-604.

ROY, J. L. \& PARK, J. K. 1974. The magnetization process of certain red beds: Vector analysis of chemical and thermal results. Canadian Journal of Earth Sciences, 11, 437-471.

ROY, J. L. \& LAPOINTE, P. L. 1978. Multiphase magnetizations: problems and implications. Physics of the Earth \& Planetary Interiors, 16, 20-37.

ROY, J.L. \& MORRIS, W.A. 1983. A review of palaeomagnetic results from the Carboniferous of North America; the concept of Carboniferous geomagnetic field horizon markers. Earth Planet. Sci. Letters., 65, 167-181.

ROY, J. L., ROBERTSON, W. A. \& PARK, J. K. 1968. Stability of the magnetization of the Hurley Creek Formation. Journal of Geophysical Research, 73, 697-702.

RUNCORN, SK. 1956, Paleomagnetic survey in Arizona and Utah: Preliminary results. Geol. Soc. America Bull., 67, 301-316.

SALTZMAN, M. R. 2003. Late Paleozoic ice age: Oceanic gateway or $\mathrm{pCO}_{2}$ ?. Geology, 31, 151-154.

SCATTERDAY, J. W. 1963. Stratigraphy and conodont faunas of the Maxville group (Middle and Upper Mississippian) of Ohio. Unpubl Ph. D., The Ohio State University, Columbus.

SCHALTEGGER, U. 2000. U-Pb geochronology of the Southern Black Forest Batholith (Central Variscan Belt): timing of exhumation and granite emplacement. International Journal of Earth Sciences, 88, 814-828.

SCHMIDT, P. W., AUBOURG, C., LENNOX, P. G. \& ROBERTS, J. 1994. Palaeomagnetism and tectonic rotation of the Hastings Terrane, eastern Australia. Australian Journal of Earth Sciences, 41, 547560.

SCHMIDT, P.W. 1988. A rapid Carboniferous polar shift of New England from palaeomagnetism. In: J.D. KLEEMAN (ed.), New England orogen tectonics \& metallogenesis, University of New England, Armidale New South Wales, 192-198.

SCHMITZ, M. D. \& DAVYDOV, V. I. 2012. Quantitative radiometric and biostratigraphic calibration of the Pennsylvanian-Early Permian (Cisuralian) time scale and pan-Euramerican chronostratigraphic correlation. GSA Bulletin, 124, 549-577.

SCOTESE, C. R., VAN DER VOO, R., JOHNSON, R. E. \& GILES, P. S. 1984. Paleomagnetic results from the Carboniferous of Nova Scotia. American Geophysical Union, Geodynamics Series, 12, 63-81.

From Lucas, Schneider et al. (eds) The Carboniferous Timescale, Spec. Publ. Geol. Soc. Lond. 
SEGUIN, M. K., SINGH, A. \& FYFFE, L. 1985. New paleomagnetic data from Carboniferous volcanics and red beds from central New Brunswick. Geophysical Research Letters, 12, 81-84.

SEVASTOPULO, G. D. \& BARHAM, M. 2014. Correlation of the base of the Serpukhovian Stage (Mississippian) in NW Europe. Geological Magazine, 151, 244-253.

SMITH, R., MARTILL, D. M. \& DUFFIN, C. 2017. The shark-beds of the Eyam Limestone Formation (Lower Carboniferous, Visean ) of Steeplehouse Quarry, Wirksworth, Derbyshire, UK. Proceedings of the Geologists' Association, 128, 374-400.

SOBCZAK, K., BRYAN, S. E., FIELDING, C. R. \& CORKERON, M. 2019. From intrabasinal volcanism to farfield tectonics: causes of abrupt shifts in sediment provenance in the Devonian-Carboniferous Drummond Basin, Queensland. Australian Journal of Earth Sciences, 66, 497-518.

SOMERVILLE, I. D. 2008. Biostratigraphic zonation and correlation of Mississippian rocks in Western Europe: some case studies in the late Visean /Serpukhovian. Geological Journal, 43, 209-240.

SOMERVILLE, I. D. \& STRANK, A. R. E. 1984. The recognition of the Asbian/Brigantian boundary fauna and marker horizons in the Dinantian of North Wales. Geological Journal, 19, 227-237.

STEIN, E. 2001. The geology of the Odenwald crystalline complex. Mineralogy \& Petrology, 72, 7-28.

STEINER, M. B. 1988. Paleomagnetism of the Late Pennsylvanian and Permian: A test of the rotation of the Colorado Plateau. Journal of Geophysical Research: Solid Earth, 93, 2201-2215.

STOJANOVIC, D., AITCHISON, J. C., ALI, J. R., AHMAD, T. \& DAR, R. A. 2016. Paleomagnetic investigation of the Early Permian Panjal Traps of NW India; regional tectonic implications. Journal of Asian Earth Sciences, 115, 114-123.

STORETVEDT, K. M. 1970. On remagnetization problems in palaeomagnetism: further considerations. Earth \& Planetary Science Letters, 9, 407-415.

STORETVEDT, K. M. 2016. A Personal History of the Remagnetization Debate: Accounting for a Mobilistic Earth. New Concepts in Global Tectonics Journal, 4, 322-344.

STACEY, F. D. 1959. Spinner-magnetometer for thermal demagnetization experiments on rocks. Journal of Scientific Instruments, 36, 355.

STRANK, A. R. E. 1985. The Dinantian biostratigraphy of a deep borehole near Eyam, Derbyshire. Geological Journal, 20,227-237.

SYMONS, D. T. A. \& STUPAVSKY, M. 1974. A rational paleomagnetic stability index. Journal of Geophysical Research, 79, 1718-1720.

TABAUD, A. S., WHITECHURCH, H., ROSSI, P., SCHULMANN, K., GUERROT, C. \& COCHERIE, A. 2014. Devonian-Permian magmatic pulses in the northern Vosges Mountains (NE France): result of continuous subduction of the Rhenohercynian Ocean and Avalonian passive margin. In: Schulmann, K., Martínez Catalán, J. R., Lardeaux, J. M., Janoušek, V. \& Oggiano, G. (eds). The Variscan orogeny: extent, timescale and the formation of the european crust. Geological Society, London, Special Publications, 405, 197-223.

TAUXE, L., SHAAR, R., JONESTRASK, L., SWANSON-HYSELL, N. L., MINNETT, R., KOPPERS, A. A. P CONSTABLE, C. G. JARBOE, N., GAASTRA, K. \& FAIRCHILD, L. 2016. PmagPy: Software package for paleomagnetic data analysis and a bridge to the Magnetics Information Consortium (MagIC) Database. Geochemistry, Geophysics, Geosystems, 17, 2450-2463.

THOMINSKI, H. P., WOHLENBERG, J. \& BLEIL, U. 1993. The remagnetization of Devonian-Carboniferous sediments from the Ardenno-Rhenish Massif. Tectonophysics, 225, 411-431.

TORSVIK, T.H., LYSE, O., ATTERAS, G., BLUCK, B.J., 1989. Palaeozoic palaeomagnetic results from Scotland and their bearing on the British apparent polar wander path. Phys. Earth Planet. Int., 55, 93-105.

From Lucas, Schneider et al. (eds) The Carboniferous Timescale, Spec. Publ. Geol. Soc. Lond. 
TORSVIK, T. H., VAN DER VOO, R., PREEDEN, U., MAC NIOCAILL, C., STEINBERGER, B., DOUBROVINE, P. V., VAN HINSBERGEN, D.J.J., DOMEIER, M., GAINA, C., TOHVER E., MEERT J.G., MCCAUSLAND, P.J.A. \& COCKS, R.M. 2012. Phanerozoic polar wander, palaeogeography and dynamics. Earth-Science Reviews, 114, 325-368.

TRENCH, A., MCKERROW, W. S., TORSVIK, T. H., LI, Z. X. \& MCCRACKEN, S. R. 1993. The polarity of the Silurian magnetic field: indications from a global data compilation. Journal of the Geological Society, 150, 823-831.

TURNER, P. 1975. Depositional magnetization of Carboniferous limestones from the Craven Basin of northern England. Sedimentology, 22, 563-581.

TURNER, P. \& TARLING, D. H. 1975. Implications of new palaeomagnetic results from the Carboniferous System of Britain. Journal of the Geological Society, 131, 469-488.

TURNER, P. METCALFE, I. \& TARLING, D.H. 1979. Palaeomagnetic studies of some Dinantian limestones from the Craven Basin and a contribution to Asbian magnetostratigraphy. Proc. York Geol. Soc., 42, 371-396.

TURNER, P., VAUGHAN, D. J. \& BESLY, B. 1985. Remanence acquisition in red beds from the Coal Measures of Central England. Journal of the Geological Society, 142, 1015-1028.

WALKDEN, G. M. 1977. Volcanic and erosive events on an upper Visean carbonate platform, north Derbyshire. Proceedings of the Yorkshire Geological Society, 41, 347-366.

WATERS, C.N.; SOMERVILLE, I.D.; JONES, N.S.; CLEAL, C.J.; COLLINSON, J.D.; WATERS, R.A.; BESLY, B.M.; DEAN, M.T.; STEPHENSON, M.H.; DAVIES, J.R.; FRESHNEY, E.C.; JACKSON, D.I.; MITCHELL, W.I.; POWELL, J.H.; BARCLAY, W.J.; BROWNE, M.A.E.; LEVERIDGE, B.E.; LONG, S.L.; MCLEAN, D. 2011. A revised correlation of Carboniferous rocks in the British Isles. Geological Society of London Special Report 26.

WATERS, C. N., WATERS, R. A., BARCLAY, W. J. \& DAVIES, J. R. 2009. A lithostratigraphical framework for the Carboniferous successions of southern Great Britain (Onshore). British Geological Survey, Research Report RR/09/01.

UTTING, J. \& GILES, P. S. 2008. Palynostratigraphy and lithostratigraphy of Carboniferous Upper Codroy Group and Barachois Group, southwestern Newfoundland. Canadian Journal of Earth Sciences, 45, 45-67.

UTTING, J., GILES, P. S. \& DOLBY, G. 2010. Palynostratigraphy of Mississippian and Pennsylvanian rocks, Joggins area, Nova Scotia and New Brunswick, Canada. Palynology, 34, 43-89.

UTTLEY, J. S. 1974. The stratigraphy of the Maxville Group of Ohio and correlative strata of adjacent areas. Unpubl. Ph.D, Ohio State University, Columbus.

VAN DER VOO, R. \& KLOOTWIJK, C. T. 1972. Paleomagnetic reconnaissance study of the Flamanville granite with special reference to the anisotropy of its susceptibility. Geol. Mijnbouw, 51, 609-617.

VAN DER VOO, R. \& TORSVIK, T. H. 2012. The history of remagnetization of sedimentary rocks: deceptions, developments and discoveries. In: Elmore, R. D., Muxworthy, A. R. Aldana, M. M. Mena, M. (eds.) Remagnetization \& chemical alteration of sedimentary rocks, Geological Society, London, Special Publications, 371, 23-53.

WAGNER, R.H. 1984. Macrofloral zones of the Carboniferous. Compte Rendu, 9th international congress of Carboniferous stratigraphy \& geology, 2, 109-134

WALTERS, S. G. \& INESON, S.G. 1981. A review of the distribution and correlation of igneous rocks in Derbyshire, England. Mercian Geologist, 8, 81-132.

WANG, X., ROBERTS, J. \& SCHMIDT, P. 2001. Flow directions of Carboniferous ignimbrites, southern New England Orogen, Australia, using anisotropy of magnetic susceptibility. Journal of Volcanology

From Lucas, Schneider et al. (eds) The Carboniferous Timescale, Spec. Publ. Geol. Soc. Lond. 
\& Geothermal Research, 110, 1-25.

WEBER, L.J., FRANCIS, B.P., HARRIS, P.M. \& CLARK, M. 2008. Stratigraphy, Lithofacies, and Reservoir Distribution - Tengiz Field, Kazakhstan. Search \& Discovery Article \#20059.

http://archives.datapages.com/data/sepm_sp/SP78/Stratigraphy_Lithofacies_and_Reservoir.pdf

WENDT, J., KAUFMANN, B., BELKA, Z. \& KORN, D. 2009. Carboniferous stratigraphy and depositional environments in the Ahnet Mouydir area (Algerian Sahara). Facies, 55, 443-472.

WESTPHAL, M., EDEL, J. B., KADZIALKO-HOFMOKL, M., JELENSKA, M. \& GROCHOLSKI, A. 1987. Paleomagnetic study of upper Carboniferous volcanics from Sudetes (Poland). Journal of Geophysics, 61, 90-96.

WILL, T. M., SCHULZ, B. \& SCHMÄDICKE, E. 2017. The timing of metamorphism in the OdenwaldSpessart basement, Mid-German Crystalline Zone. International Journal of Earth Sciences, 106, 1631-1649.

WILSON, R. L. 1960. Thermo-magnetic analysis of some British Laterites and basalts. Unpubl. PhD thesis, Univ. of London.

WILSON, R. L. 1961. The thermal demagnetization of natural magnetic moments in rocks. Geophysical Journal International, 5, 45-58.

WILSON, R. L. 1966. Further correlations between the petrology and the natural magnetic polarity of basalts. Geophysical Journal International, 10, 413-420.

WILSON, R. L. \& WATKINS, N. D. 1967. Correlation of petrology and natural magnetic polarity in Columbia Plateau basalts. Geophysical Journal International, 12, 405-424.

WILSON, R. L. \& EVERITT, C. W. F. 1963. Thermal demagnetization of some Carboniferous lavas for palaeomagnetic purposes. Geophysical Journal International, 8, 149-164.

WILSON, R.M. 1980. A goniatite from the Mill Hill Marine Band, Lower Limestone Griup of east Fife. Scott J. Geology, 16, 33-34.

WOOD JR, G. H., TREXLER, J. P. \& KEHN, T. M. 1969. Geology of the west-central part of the Southern Anthracite Field and adjoining areas, Pennsylvania. Geological Survey Prof. Paper 602. US Govt. Print. Office.

$\mathrm{XIAOCHI,} \mathrm{J.} \mathrm{2002.} \mathrm{Permo-Carboniferous} \mathrm{sequences} \mathrm{of} \mathrm{Gondwana} \mathrm{affinity} \mathrm{in} \mathrm{southwest} \mathrm{China} \mathrm{and} \mathrm{their}$ paleogeographic implications. Journal of Asian Earth Sciences, 20, 633-646.

XU, W., SUN, Z., SHI, G. R., LU, J., YU, L., NIU, Y., ZHAO, Y., HAN, X., WANG, B., SONG, B., \& CAO, Y. 2019. First report of coupled Early Permian paleomagnetic and geochronologic data from the Dunhuang block (NW China), and implications for the tectonic evolution of the Paleo-Asian ocean. Gondwana Research, 67, 46-63.

YI, Z., HUANG, B., XIAO, W., YANG, L. \& QIAO, Q. 2015. Paleomagnetic study of Late Paleozoic rocks in the Tacheng Basin of West Junggar (NW China): Implications for the tectonic evolution of the western Altaids. Gondwana Research, 27, 862-877.

ZEGERS, T.E. DEKKERS, M.J. \& BAILLY, S. 2003. Late Carboniferous to Permian remagnetisation of Devonian limestones in the Ardennes: Role of temperature, fluids and deformation. Jour. Geophys Res., 108, doi:10.1029/2002JB002213.

ZHAO, P., APPEL, E., XU, B. \& SUKHBAATAR, T. 2020. First paleomagnetic result from the Early Permian volcanic rocks in northeastern Mongolia: evolutional implication for the paleo-asian ocean and the Mongol-Okhotsk Ocean. Journal of Geophysical Research: Solid Earth, 125, doi.org/10.1029/2019JB017338.

ZIEGLER, A. M., REES, P. M. \& NAUGOLNYKH, S. V. 2002. The Early Permian floras of Prince Edward Island, Canada: differentiating global from local effects of climate change. Canadian Journal of

From Lucas, Schneider et al. (eds) The Carboniferous Timescale, Spec. Publ. Geol. Soc. Lond. 
Earth Sciences, 39, 223-238.

ZWING, A. \& BACHTADSE, V. 2000. Paleoposition of the northern margin of Armorica in Late Devonian times: Paleomagnetic and rock magnetic results from the Frankenstein Intrusive Complex (Mid-German Crystalline Rise. Journal of Geophysical Research: Solid Earth, 105, 21445-21456.

\section{Figure Captions}

Fig. 1. Magnetostratigraphic data from the Donets Basin of Khramov et al. (1974), showing the magnetic polarity and the sample declination in the four sections. Each of the sections is drawn with the same thickness scale. $F_{1}$ to $N_{1}$ are the standard limestone codes, and $C_{1}{ }^{5}$ to $C_{2}{ }^{1}$ are the standard formation codes as shown in Davydov et al. (2010), along with the regional substage names. The correlated European regional substages and million year ages (Ma) are derived from Fig. 2 of Davydov et al. (2010). The limestones are often considered chronostratigraphic horizons, although this may not always be the case (Davydov et al. 2010). The composite polarity column is constructed using the formations and limestone units, except for around the $L_{1}$ limestone, where $L_{1}$ may be diachronous with respect to the two apparent normal magnetozones at this level.

Fig. 2. The Russian 'general magnetostratigraphic scale' in the summaries of Khramov \& Rodionov (1980), its major update formalised into the Russian stratigraphic code (Khramov \& Shkatova 2000). Stage relationships of these two scales indicated. Rightmost is the modification of the 2000 scale by Molostovsky et al. (2007) and its 'time-matching' to the ICS 2008 timescale as used and listed in Table 1 of Perchersky et al. (2010), with the apparent magnetostratigraphic relationships to the Khramov \& Shkatova (2000) scale indicated.

Fig. 3. Polarity bias data for the Carboniferous, using data from intrusive and extrusive igneous rocks (Table 1). The age boundaries of the ICS 2012 stage boundaries (Richards 2013) are placed on the age axis. The bias of some $0 \%$ or $100 \%$ data points has been adjusted to provide non-overlapping age confidence intervals (as in Table 1 ).

Fig. 4. Polarity ( $N=$ normal, $R=$ reverse) of palaeomagnetic sampling sites from the Tamworth Belt of the New England Orogen from Geeve et al. (2002) and Klootwijk $(2016,2019)$, placed onto the adapted Fig. 3. of Klootwijk (2016). Those palaeomagnetic sites without polarity label, did not work. The stages are placed according to the correlations in Roberts (1975), Roberts et al (1993) and the Belgium substages according to Poty et al. (2014). SHRIMP U-Pb dates are those outlined in Klootwijk (2016), with the adjusted age in [..],according to the factors in Black et al. (2003a), to convert the AS3 and SL13 standards to be consistent with the Temora-1 standard. \$=SL13 standard, *=AS3 standard. Klootwijk (2016) data through the mid Visean Gilmore volcanic are sufficiently close for a mini-magnetostratigraphy. Klootwijk (2016) sites 2-6 in the Foybrook Andesite (Waverly $\mathrm{Fm}$ ), where moved to near the base of the Waverly Fm in Klootwijk (2019). The normal polarity magnetozones through the Visean have been labelled (TB for Tamworth Belt).

Fig. 5. Polarity of palaeomagnetic sampling sites in the Caroda Formation, from the northern and central Tamworth Belt of the New England Orogen. The Caroda Fm has brachiopod fauna of the tenuirugosus Subzone of the Delepinea aspinosa Zone (Roberts 1975). CA1,CA2, CA3 and CA5 are volcanic member codes of Roberts et al. (2003a). Age of the Caroda Fm is mid to possibly late Visean (Mory 1980, Roberts et al. 2003a), based largely on conodonts (Jenkins et al. 1993). Barneys Spring Andesite SHRIMP age from supplementary information in Roberts et al. (2003a). The Trevallyn section is assigned to the Caroda Fm based on Opdyke et al. (2000) and Roberts et al. (2003a), not the alternative in Klootwijk (2002). Biozones and ages on Merlewood Fm based on Roberts et al. (1993) and Roberts \& James (2010).

From Lucas, Schneider et al. (eds) The Carboniferous Timescale, Spec. Publ. Geol. Soc. Lond. 
Fig. 6. Polarity ( $\mathrm{N}=$ normal, $\mathrm{R}=$ reverse) of palaeomagnetic sampling sites from the Tamworth Belt of the northern New England Orogen. Site numbers in black from Opdyke et al. (2000) and those in blue from Klootwijk (2002). The original site positions have been simplified onto a smaller number of sections by lateral correlation, using the correlations in the original publications. Data from The Pine Cliffs section (shown on the Arizona-Barneys springs section) is the correlation based on Roberts et al. 2003a), not the alternative in Klootwijk (2002). For the SHRIMP dates, red dots are dates in shown section, blue correlated from other section. The position of the $\mathrm{C} 1$ and $\mathrm{C} 3$ glaciations are those described by Fielding et al. (2008) and Birgenheier et al. (2009). Ages on the composite polarity column are adjusted SHRIMP dates according to conversion factors in Black et al. (2003a), converting SHRIMP AS3 and SL13 standards to be consistent with the Temora-1 standard. Likely disconformities based on Roberts et al. (2003a). Ticks on composite polarity column are correlated site locations from all sections.

Fig. 7. Polarity ( $\mathrm{N}=$ normal, $\mathrm{R}=$ reverse) of palaeomagnetic sampling sites from the Werrie Block of the Tamworth Belt (New England Orogen, E. Australia). Site numbers of Opdyke et al. (2000) in black, and Klootwijk (2003) in blue on the composite section of Opdyke et al. (2000). Volcanic level labels after McPhie (1984) and Opdyke et al. (2000). Note, the interval with glacial sediments (C3 glacial of Fielding et al. 2008) is placed in the Currabubula Fm below the Canna Creek Tuff (CC) according to McPhie (1984). SHRIMP dates as in caption to Fig. 4. ). Ticks on composite polarity column are correlated site locations.

Fig. 8. Polarity data of Derbyshire lavas from Piper et al. (1991) redrawn onto logs generalised from Walters \& Ineson (1981). [..] site numbers of Piper et al. (1991). Bonsall Moor-Matlock log from Walters and Ineson (1981) Fig. 2 (3 left-hand logs), Lathkill Dale log from their Fig. 8; Shacklow Wood log, from their Fig. 10; Cressbrook Dale-Great Rocks Dale log from their fig. 14 (rightmost 5 logs); Castleton-Bradwell Moor log from their Fig. 16 (left-most 3 logs). The lithostratigraphy is from Waters et al. (2009) with other stratigraphic details from Butcher \& Ford (1973), Walters \& Ineson (1981), Gatliff (1982) and Gutteridge (1989). Correlations in the southern locations based on Bridge \& Gozzard (1981), and for the Litton Tuff from Butcher \& Ford (1973). Thicknesses of formation units in the Lathkill Dale-Matlock area from Cox \& Harrison (1980) and Bridge \& Gozzard (1981). Waters et al. (2011) place the Conksbury and Lathkill lavas (and limestone between and below) within the Fallgate Volcanic Fm (not followed here for sake of simplification).

Fig. 9. Magnetic polarity data from the Kinghorn Volcanic Formation, from Wilson \& Everitt (1963) and Torsvik et al. (1989) placed onto the log of Allan (1923). Bed numbers are those of Allan (1923) with [..] indicating equivalent bed numbers used by Wilson \& Everitt (1963), if different. Part of the log in the Lower Limestone Fm is based on Karbub (1993), and the stratigraphic distances to units below the Kinghorn Volcanic Fm is based on Francis (1961). Positions of sampling sites of Torsvik et al. (1989) are based on transposing their map locations onto Fig. 1 of Brindley \& Spinner (1989), giving an approximate position (their site numbers shown), based on the bed outcrop details in Allan (1923). On the log bed numbers the $b$ and $s$ postfix are the percent ilmenite values of Wilson (1966) divided into a big ( $>9 \%$ ilmenite) and small ( $<9 \%$ ilmenite) classes. The tabular data is the number of flow or intrusive units with petrological classifications of Allan (1923) in the two \% ilmenite classes (from Wilson 1966), and the number of units with reverse (R) or normal (N) polarity.

Fig. 10. Magnetic polarity data for the Mauch Chunk Fm, E. Pennsylvania (DiVenere \& Opdyke 1991, Opdyke \& DiVenere 2004). The sedimentary log for the Jim Thorpe section is from Epstein et al. (1974); their section 19, place alongside the thickness scale of Opdyke \& DiVenere (2004).

From Lucas, Schneider et al. (eds) The Carboniferous Timescale, Spec. Publ. Geol. Soc. Lond. 
Lithostratigraphy is that of Filmore et al. (2012), using the lower, middle, upper divisions of the Mauch Chunk Fm of Wood et al. (1969) and Jennings (1985). The position of Adiantitites antiquus in the Schuylkill Gap section is base on correlation of the logs of this section (shown) in Jennings (1985) against that in DiVenere \& Opdyke (1991). Mauch Chunk member thickness and missing strata estimates based on Wood et al. (1969) and Epstein et al. (1974). Calcrete levels in the Schuylkill Gap section from Levine \& Slingerland (1987), which can be related to the re-drafted log of DiVenere \& Opdyke (1991). There is no calcrete data from the lower part of the Schuylkill section. The Hometown Mbr is largely calcrete-free (Levine \& Slingerland 1987). Two possible options of how to relate the south Lavelle and Jim Thorp sections are shown.

Fig. 11. Lithostratigraphy and age control for the Mauch Chunk Fm and adjacent units in a SW to ENE transect across Pennsylvania. Lithostratigraphic relationships based on Berg et al. (1983), Brezinski (1989a, 1999), Edmunds (1996), Edmunds et al. (1999). Magafloral zones are those of Read and Mamay (1964) slightly modified as outlined by Eble et al. (2009), with relationship to Pennsylvanian strata as in Edmunds et al. (1999). LM= Loyalhanna Mbr and equivalents, DVL=Deer Valley Limestone, RL=Reynolds Limestone, WGL=Wymps Gap Limestone, PS=Patton (red) Shale, CLS= Campbells Ledge Shale. The greyed 3a megafloral zone is not known from Pennsylvania, but from the equivalent interval in Virginia (Eble et al. 2009).

Fig. 12. Magnetic polarity data from the Cumberland Basin and Cape Breton Island sections, New Brunswick and Nova Scotia, derived from DiVenere \& Opdyke (1990, 1991b) and Opdyke et al. (2014). Lithostratigraphy and hiatus in the Cumberland Basin sections from Jutras et al. (2015, 2016). Magnetozones re-labelled from Opdyke et al. (2014) to NN after New Brunswick- NovaScotia. It is not clear how the hiatus on the basal Enragé Fm in the Maringouin Peninsula of Jutras et al. (2015), relates to the Maringouin Peninsula column data. Sloping boundary on polarity composite = uncertainty in placing the biozone boundary. N.D=no palynology data, a-t Z.=S. acadiensis- $K$. triradiatus Zone.

Fig. 13. Magnetostratigraphic data for wells from the Tengiz carbonate platform, Kazakhstan (adapted from Ratcliffe et al. 2013). Codes for sequence stratigraphic boundaries (in grey box) and the chemostratigraphic divisions, based on trace element geochemistry, are shown with greyed numbers. See Kenter et al. (2006) for sequence stratigraphic codes.

Fig. 14. A) Carbon isotope datasets for the two wells (T-220, T-5853) from the Tengiz carbonate platform (from Ratcliffe et al. 2013) compared to similar aged units from the Antler Basin, Idaho, USA (Batt et al. 2007), the Askyn River section, S. Urals (Kuleshov et al. 2018) and the Pennsylvanian/Bashkirian in Arrow Canyon, Nevada, USA (Saltzmann, 2003). Codes for sequence stratigraphic boundaries in grey box, and their relationship to the Russian horizons based on Weber et al. (2008). Isotope correlations (shown in grey) and other correlations in black. The Arrow Canyon and Askyn River sections shows the abbreviated conodont zones: nod=Declinognathodus noduliferous; $\sin =$ Idiognathoides sinuatus; $\mathrm{b}-\mathrm{s}=$ Neognathodus symmetricus- $N$. bassieri Zone; $\mathrm{k}-\mathrm{s}=$ Idiognathodus klapperi - I. sinuosus Zone; con= Id. convexus; Prof= Profusulinella; Fus= Fusulinella . Corr= Id. corrugates; ask= N. askynensis; $\operatorname{marg}=D$. marginodosus; don= D. donetzianus.

Biostratigraphic correlation (dotted lines) between the Arrow Canyon section and the Bashkirian in the Askyn River based on Nemirovskaya \& Alekseev (1994), Groves et al. (1999), Kulagina et al. (2009) and Hu et al. (2017). B) The table shows the stratigraphic relationships of the Russian horizons and the British substages (based on Richards 2013 and Kuleshov et al. 2018).

Fig. 15. Summary magnetostratigraphic and polarity bias data for the early - mid Mississippian. Igneous and sedimentary rock polarity bias data from Tables 1 and 2 . Magnetozones and polarity bias zones

From Lucas, Schneider et al. (eds) The Carboniferous Timescale, Spec. Publ. Geol. Soc. Lond. 
in the composite polarity labelled MI (for Mississippian). The detailed late Visean and Serpukhovian magnetostratigraphy is from Fig. 16, expressing the incompleteness of the Tamworth Belt polarity data. Daposhang magnetostratigraphy, conodont zones and radioisotopic date from Liu et al. (1991, 2012). At ages older than MI4r, magnetozones are intervals of reverse or normal polarity bias. The Lower crenulata conodont zone for the Brush Hill Limestone (in sol brachiopod Zone) from Mory \& Crane (1982).

Fig. 16. Summary magnetostratigraphic data for the late Mississippian and earliest Pennsylvanian. Magnetozones in the composite polarity, labelled MI (for Mississippian) and PE (for Pennsylvanian), beginning the PE magnetozones in the first zone which overlaps the base of the Bashkirian. Two options of how to correlate the Mauch Chunk Fm magnetostratigraphy are shown, with Option-2 the preferred one, which is in part used to scale the composite polarity column. A/F=ammonoid or foraminifera zone (estimated position). Radioisotopic dates on composite polarity from Table 3.

Fig.17. a) Summary magnetostratigraphic data for the Bashkirian and Moscovian, based around the composite from Fig. 1. The earliest part of the Bashkirian is shown in Fig. 16. B) Polarity bias data for the Moscovian to Gzhelian from Tables 1 and 2. Radioisotopic dates on composite polarity column from Table 3.

Fig. 18. Optimised composite ( $a, b)$ and age model for the Carboniferous. c) Optimised composites based on methodology in Hounslow (2016). A) The standard deviation $\left(\sigma_{T}\right)$ for the levels used in the optimised scaling procedure (scaled to Ma, using the final age model). This is a measure of the correlated magnetozone misfit (i.e. the small divergences between the original relative position of sections and the final optimized composite position in b)). No $\sigma_{T}$ values for a corresponding level shown in b) indicate the level was not used to constrain the optimised model, but simply scaled with the section. B) The original section data shown on the $y$-axis (in a relative height scale), along with the final composite position of the levels on the x-axis. Minor scatter in the y-axis relates to the degree of between-section misfit expressed in the overlying panel as $\sigma_{\mathrm{T}}$. Numbers in brackets (..) next to section names are the $D_{j}$ values of Hounslow (2016), which express the general mis-fit of the section data to the optimised composite. i.e. the Schuylkill Gap data has a mean residual of $14 \%$ per average 'chron width' in the optimised model. $D_{s}$ is the average of the $D_{j}$ values across all sections. C) The Bchron age model for the Carboniferous, showing the scaling of optimised position to Ma, using the radioisotopic dates. Magnetochrons in scale of optimised composite on $\mathrm{x}$-axis and in Bchron-scaled Ma on y-axis. Radioisotopic dates used to scale the optimised composite have analytical uncertainties on the $y$-axis $\left(\sigma_{R}\right)$ and stratigraphic uncertainties $\left(e_{s}\right)$ on the $x$-axis (values from Table 3). D) Percent reverse polarity using a 4-chron width window. The mid point between the $20 \%$ and $80 \%$ crossing points is used to fix the base of the Kiaman Superchron.

Fig. 19. a) Summary geomagnetic polarity timescale (GPTS) data for the Carboniferous, with the CONOPbased ages for the stage bases (blue arrows) from Aretz et al. (2020). The stage names shifted to the right express stage boundary positions entirely based on Aretz et al. (2020), whereas those on the left, and regional substages are based on this magnetozone-stage position from this work (Gzhelian to base Asselian from Hounslow \& Balabanov, 2018). b) type of data which has contributed to the timescale, as an expression of 'data-confidence'. c) Uncertainty from the statistical compositing procedure expressed as the age scaled value of two times the $\sigma_{T}$ value, which is a kind of 'between-section magnetozone position' uncertainty. d) The confidence interval for the age of magnetochron bases, which is the shortest interval of time that encompasses $95 \%$ of the simulated ages at the position of the magnetochron. Abbreviated substages in oldest to youngest order: Pendleian, Arnsbergian, Syuranian, Akavasian, Prikamian, Cheremshankian, From Lucas, Schneider et al. (eds) The Carboniferous Timescale, Spec. Publ. Geol. Soc. Lond. 
Melekessian, Vereian (base Moscovian), Kashirian, Podolskian, Myachokovian, Rusavkinian (base Gzhelian), Pavlovoposadian, Noginian, Melekhovian, base Asselian and Permian. 


\begin{tabular}{|c|c|c|c|c|c|c|c|}
\hline Stratigraphic age & $\begin{array}{l}\text { Date } \\
\text { (Ma) }\end{array}$ & Date type & $\begin{array}{l}\text { Mid-age } \\
(\mathrm{Ma})\end{array}$ & $\begin{array}{c}\mathrm{Cl} \\
(\mathrm{Ma})\end{array}$ & $\% R$ & Palaeomag. ref & Age reference \\
\hline- & $283(3)$ & U-Pb.IZ & 283 & 3 & 100 & Zhao et al. 2020 & \\
\hline- & $\begin{array}{l}280.6- \\
291.4\end{array}$ & U-Pb.IZ & 286 & 5.4 & 98 & Xu et al. 2019 & \\
\hline- & $289(3)$ & U-Pb.IZ & 289 & 3 & 100 & Stojanovic et al. 2016 & \\
\hline - & $300-280$ & $\mathrm{Rb} / \mathrm{Sr} . \mathrm{w}$ & 290 & 10 & 100 & $\begin{array}{l}\text { Klootwijk 1993; Giddings } \\
1993\end{array}$ & Korsch et al. 2009 \\
\hline- & $291(5)$ & $\mathrm{Rb} / \mathrm{Sr}$ & 291 & 5 & 100 & Martin et al. 1978 & Gasquet et al. 1992 \\
\hline- & $294(2)$ & $\mathrm{Ar} / \mathrm{Ar}$ & 294 & 2 & 100 & Liss et al. 2004 & \\
\hline - & $294.2(2.1)$ & U-Pb.SZ & 294.2 & 2.1 & 100 & Nawrocki et al. 2008 & \\
\hline- & $295(6)$ & $\mathrm{K}-\mathrm{Ar}$ & 295 & 6 & 100 & Liss et al. 2004 & \\
\hline- & $297(0.5)$ & U-Pb.b & 297 & 0.5 & 100 & Liss et al. 2004 & \\
\hline Gzhelian- Asselian & & & $299^{*}$ & 5 & 100 & Huang \& Opdyke1991 & Xiaochi 2002 \\
\hline- & $300.1(6.1)$ & U-Pb.Z & 300.1 & 6.1 & 100 & Edel et al. 2014 & \\
\hline $\begin{array}{l}\text { U. Carboniferous (Ar-Ar } \\
\text { near top) }\end{array}$ & $304(4.7)$ & Ar/Ar.G & 305 & 4.7 & 94 & Yi et al. 2015 & \\
\hline - & $\begin{array}{l}302.9- \\
308.4\end{array}$ & U-Pb.SZ & 305.65 & 3 & 100 & Halvorsen et al. 1989 & Mikulski et al. 2013 \\
\hline- & $305.9(2.4)$ & U-Pb.SZ & 305.9 & 2.4 & 86 & Beck et al. 1991 & Deckart et al. 2014 \\
\hline Stephanian & $308(5)$ & U-Pb.TZ & 308 & 5 & 100 & Torsvik et al. 1989 & Monaghan et al. 2014 \\
\hline- & $308(2.9)$ & $\mathrm{U}-\mathrm{Pb} . \mathrm{Z}$ & 308 & 2.4 & 100 & Edel et al. 2014 & \\
\hline- & $310(6.8)$ & $\mathrm{K} / \mathrm{Ar}, \mathrm{Rb} / \mathrm{Sr}$ & 310 & 6.8 & 100 & Facer 1976 & Facer 1978 \\
\hline Late Bolsovian & & & 312 & 2.5 & 59 & Everitt 1960 & Kirton 1984 \\
\hline- & $312.4(0.3)$ & $\mathrm{Rb}-\mathrm{Sr}, \mathrm{Sz}, \mathrm{TZ}$ & 312.4 & 0.5 & 50 & Halvorsen et al. 1989 & Kryza et al. 2014 \\
\hline- & $314(2)$ & U-Pb.IZ & 314 & 2 & 100 & Dooley 1983 & Mobley et al. 2014 \\
\hline $\begin{array}{l}\text { I. Westph.B to Westph. } \\
\text { C or D }\end{array}$ & - & & $312.5^{\star}$ & 2.5 & 100 & Westphal et al. 1987 & \\
\hline- & $313(4)$ & $\mathrm{Rb} / \mathrm{Sr} . \mathrm{bW}$ & 313 & 4 & 100 & Dooley 1983 & Fullagar et al. 1997) \\
\hline- & $320-311$ & U-Pb.IZ & 315.5 & 4.5 & 60 & Edel et al. 2014 & \\
\hline none & $318(2.2)$ & U-Pb.IZ & 318 & 2.2 & 100 & Pisarevsky et al. 2016 & \\
\hline- & $318.1(1.5)$ & U-Pb.IZ & 318.1 & 1.5 & 100 & $\begin{array}{l}\text { Van der Voo \& Klootwijk } \\
\text { 1972; Cogné } 1988\end{array}$ & Erwan et al. 2018 \\
\hline e. Namurian & - & & 320.5 & 2.5 & 48 & Schmidt et al. 1994) & Birgenheier et al. 2009 \\
\hline- & $323(5)$ & $\mathrm{Ar} / \mathrm{Ar}, \mathrm{U}-\mathrm{Pb}$ & 323 & 5 & 86 & Edel \& Wickart 1991 & Will et al. 2017 \\
\hline nents $^{1}$ - & $330-320$ & $\begin{array}{l}\mathrm{Ar} / \mathrm{Ar} \text { and } \\
\text { others }\end{array}$ & 325 & 5 & 71 & $\begin{array}{l}\text { Edel \& Wickert 1991; Zwing } \\
\text { \& Bachtadse } 2000\end{array}$ & Stein 2001 \\
\hline
\end{tabular}

From Lucas, Schneider et al. (eds) The Carboniferous Timescale, Spec. Publ. Geol. Soc. Lond. 
Argyllshire, camptonite \& monchiquite dykes

Central Black Forest rhyolites, FN5,6,7

Hardwood Ridge Volcanic Mbr

("Boiestown, Royal Road")

Kudowa Granitoid

Champ du Feu Massif diorites ${ }^{2}$ Comp.C1,c2,c3

Kinghorn-Burntisland

Derbyshire lavas and intrusions

Upper Visean tuffs etc, Roanne

Kap Kolthoff \& Kap Graah series

Star of Hope Fm, Comp C3

Magerøy dykes

$\mathrm{C}$ and $\mathrm{C}^{\prime}$ comp high $\mathrm{Mg}-\mathrm{K}$ Granodiorites

Punta del Agua Formation, basalts

andesites

Garleton Hills Volcanic Fm, B Comp

Silver Hills Volcanics, Comp C3

Merlewood Fm, Werrie syncline

Tin Serririne basin intrusive, Comp. B

Cockermouth Lavas, units 3,7

Admiralty Intrusives

Admiralty extrusives, Gallipoli Volcanics

Frankenstein intrusive complex, Comp C

Achala Batholith

\begin{tabular}{|c|c|c|c|c|c|c|c|}
\hline- & & K/Ar.w & 326 & 5 & 100 & Esang \& Piper 1984 & Baxter \& Mitchell 1984 \\
\hline- & $336-320$ & U-Pb.TZ & 328 & 5 & 100 & $\begin{array}{l}\text { Edel 1987; Edel \& } \\
\text { Schneider } 1995\end{array}$ & Schaltegger 2000 \\
\hline I. Asbian- e. Brigantian & 328 & U-PB.TZ & $328^{*}$ & 1 & 85 & Seguin et al. 1985 & $\begin{array}{l}\text { Jutras et al. 2018; Park \& } \\
\text { Hinds 2019) }\end{array}$ \\
\hline - & $329(4.5)$ & $\begin{array}{l}\text { U-Pb.SZ } \\
\text { (SL13) }\end{array}$ & $332.29^{\$}$ & 4.5 & 83 & Halvorsen et al. 1989 & Mikulski et al. 2013 \\
\hline - & $331(5)$ & $\begin{array}{c}\text { K.Ar, } \mathrm{Ar} / \mathrm{Ar} . \mathrm{m} ; \\
\text { U-Pb }\end{array}$ & 331 & 5 & 61 & Edel et al. 1986 & Tabaud et al. 2014 \\
\hline I. Asbian- m. Brigantian & & & $332.5^{*}$ & 1.5 & 71 & Torsvik et al. 1989 & Monaghan et al. 2014 \\
\hline I. Asbian - e. Brigantian & & & $332.5^{\star}$ & 1.5 & 66 & Piper et al. 1991 & Harwood 2005 \\
\hline upper Visean & & & $334.5^{\star}$ & 2.5 & 67 & Edel et al. 1981 & \\
\hline- & $335.6(3.1)$ & Ar/Ar.P & 335 & 3 & 57 & Hartz et al. 1997 & \\
\hline $\begin{array}{l}50-70 \% \text { from base } \\
\text { Visean }\end{array}$ & & & $336^{*}$ & 2 & 100 & Klootwijk et al. 1993 & Sobczak et al. 2019 \\
\hline- & $337(0.4)$ & Ar/Ar.P & 337 & 0.4 & 0 & Roberts et al. 2003 & \\
\hline- & $338(2)$ & U-Pb.TZ & 338 & 2 & 50 & Edel et al. 2014 & Paquett et al. 2003 \\
\hline m. Visean & $336(1.3)$ & U-Pb.TZ & 336 & 1.3 & 100 & Geuna \& Escosteguy 2004 & Cesari et al. 2011 \\
\hline Chadian- e. Holkerian & $343(1)$ & $\mathrm{U}-\mathrm{Pb}$ & 343 & 1 & 87 & Rother \& Storetvedt 1991 & Monaghan et al. 2014 \\
\hline Tournasian & $344(3)$ & $\mathrm{U}-\mathrm{Pb}, \mathrm{K} / \mathrm{Ar}$ & 344 & 3 & 0 & Klootwijk et al. 1993 & Henderson et al. 1998 \\
\hline Molinacian- e. Livinian & & & $344^{*}$ & 2.5 & 0 & Schmidt 1988 & Roberts \& James 2010 \\
\hline- & $347.6(8.1)$ & K/Ar.w & 347.6 & 8 & 0 & Derder et al. 2006 & \\
\hline $\begin{array}{l}\text { CM Miospore zone, } \\
\text { Mid-late Ivorian }\end{array}$ & & & 348 & 1.7 & 0 & Oppenheim et al. 1994 & $\begin{array}{l}\text { Butterworth \& Butcher 1983; } \\
\text { Clayton \& Turnau } 1990\end{array}$ \\
\hline- & $364-346$ & $\mathrm{~K} / \mathrm{Ar}, \mathrm{Rb} / \mathrm{Sr}$ & 355 & 9 & 0 & Fiorett\& Lanza 2000 & \\
\hline- & $355.8(2.9)$ & U-Pb.SZ & 355.8 & 2.9 & 0 & Rolf \& Henjes-Kunst 2003 & \\
\hline- & $363(4)$ & $\mathrm{Ar} / \mathrm{Ar}, \mathrm{Pb}-\mathrm{Pb}$ & 363 & 4 & 75 & Zwing \& Bachtadse 2000 & \\
\hline- & $368(2)$ & U-Pb.TZ & 368 & 2 & 43 & Geuna et al. 2008 & \\
\hline
\end{tabular}

Table 1. Selected polarity bias data for intrusive and extrusive igneous rocks covering the Carboniferous and earliest Permian.

${ }^{1}$ Excluding sites od14,13,12,25,10. ${ }^{2}$ sites 8,13,19,20,38,3,4,10,11,12,18,36. Stratigraphic age abbreviations $=\mathrm{I} .=\mathrm{Late}, \mathrm{m} .=\mathrm{Mid}$, e.=Early, U.=Upper. Date type abbreviations: TZ=ID TIMS on zircon, SZ=SHRIMP on zircon, IZ=laser ICPMS on zircon, w=whole rock, $P=$ on plagioclase, $m=$ on mica, $b=$ on Baddeleyite, $G=$ on groundmass, bw= biotite whole rock, ${ }^{\$}=S H R I M P$ age adjusted for standard using values in Black et al. (2003a). $\mathrm{Cl}=$ confidence interval, which is quoted uncertainty on radioisotopic date, or half likely age range for a stratigraphic age. \%R= percentage of sites or samples with reverse polarity (samples used, if quoted).

Palaeomaf.ref $=$ original palaeomagnetic source, Age reference= newer reference for age determination (if none shown, using original source). ${ }^{*}$ stratigraphic age shown (from Richards 2013 timescale).

From Lucas, Schneider et al. (eds) The Carboniferous Timescale, Spec. Publ. Geol. Soc. Lond. 


\begin{tabular}{|c|c|c|c|c|c|}
\hline Location/ Age & $\begin{array}{l}\text { Lithology, } \\
\text { Lithostratigraphy }\end{array}$ & $N_{n} / R_{n}$ & $D_{m} / F T / S$ & $\mathrm{Ma}[\mathrm{Cl}]$ & References (source and updated age) \\
\hline Donbass, Kartamysh Fm / I. Gzhelian- e. Asselian & $\begin{array}{l}\text { Red and grey } \\
\text { clastics }\end{array}$ & $0 / 31+$ & $1 / \mathrm{F}+/ \mathrm{PP}$ & $298.75[1.7]$ & losifidi et al. 2010; Davydov et al. 2012 \\
\hline $\begin{array}{l}\text { Donbass, Suhoj-Jaz, mid Kartamysh Fm / I. } \\
\text { Gzhelian- e. Asselian }\end{array}$ & Red beds & $13 / 32^{*}$ & $0 / F+/ P P$ & $299.05[0.55]$ & $\begin{array}{l}\text { Khramov 1963, Khramov \& Davydov 1984, } \\
\text { Davydov \& Leven } 2003\end{array}$ \\
\hline Wescogame Fm, PS1,PS2, Arizona/ Virgillian & Red beds & $0 / 126^{+}$ & 1/0/MS & $300.45[1.6]$ & Steiner 1988; Blakey \& Middleton 2012 \\
\hline Ukraine, Avilov \& Araucarite Fms/ m. Gzhelian & $\begin{array}{l}\text { Red and grey } \\
\text { clastics }\end{array}$ & $0 / 12^{+}$ & $1 / \mathrm{F}+/ \mathrm{PP}$ & $300.95[2.25]$ & Iosifidi et al. 2010 \\
\hline $\begin{array}{l}\text { Moscow, Shchelkovo Series, Gzhel Quarry/ } 10 \% \text { of } \\
\text { e. Rusavkinian; }\end{array}$ & $\begin{array}{l}\text { Red and brown } \\
\text { clays }\end{array}$ & $0 / 14^{+}$ & $1 / 0 / \mathrm{PP}$ & $302.65[0.15]$ & $\begin{array}{l}\text { losifidi \& Mikhailova 2017; Briand et al. } \\
1998\end{array}$ \\
\hline $\begin{array}{l}\text { Noginsk,Russia, } 25 \% \text { of Dorogomilovskii } \\
\text { substage(Rusavkinian)/ e. Gzhelian }\end{array}$ & Red clays & $0 / 5^{+}$ & $1 / 0 / \mathrm{PP}$ & $302.75[0.25]$ & losifidi et al. 2018 \\
\hline $\begin{array}{l}\text { Wyoming, Lower Casper Formation/ I. } \\
\text { Desmoinesian- Missourian-Virgilian }\end{array}$ & $\begin{array}{l}\text { Red sands/siltstone, } \\
\text { Limestones }\end{array}$ & $0 / 549$ & 1/0/MS & $302.85[4.15]$ & Diehl \& Shive 1981; Burns \& Nestell 2009 \\
\hline $\begin{array}{l}\text { New Brunswick, Hurley Creek Formation/ L. } \\
\text { Bolsovian }\end{array}$ & Red beds & $0 / 20^{\&}$ & 1/0/PP & $303.5[0.5]$ & Roy et al. 1968; Gibling et al. 2019 \\
\hline N. Italy, Auernig Group/Stephanian & Limestones & $0 / 119^{*}$ & 2/0/PP & $304.75[0.25]$ & Manzoni et al. 1989 \\
\hline $\begin{array}{l}\text { Moskva River, Moscow, } 25 \% \text { of Khamovnicheskii/ } \\
\text { m. Kasimovian }\end{array}$ & Clastics? & $0 / 9^{+}$ & 1/0/PP & $304.75[0.25]$ & losifidi et al. 2018; Briand et al.1998 \\
\hline NW Bulgarian, Zverino red quartzites/ Stephanian & Red beds & $0 / 71^{*}$ & 2/0/PP & $304.75[2.75]$ & Nozharov et al. 1980 \\
\hline $\begin{array}{l}\text { Nova Scotia, Miminegash \& Egmont Bay Fms/ } \\
\text { Stephanian }\end{array}$ & Red beds & $2 / 96^{*}$ & $1 / F+/ P P$ & $304.75[2.75]$ & $\begin{array}{l}\text { Pan \& Symons 1993; Ziegler et al. 2002; } \\
\text { Tanner et al. 2005; Allen et al. } 2011\end{array}$ \\
\hline Pennsylvanian, Glenshaw Fm/ Missourian & Grey clastics & $0 / 23^{*}$ & 1/0/PP & $304.85[1.15]$ & Kodama 2009 \\
\hline SW Ningxia, Taiyuan Fm, B Comp./ Stephanian & Limestones & $0 / 16^{+}$ & 1/F+/PP & $305.5[1.5]$ & Huang et al. 2001 \\
\hline Nova Scotia, Morien (pictou) Group/ Bolsovian & Clastics, concretions & $0 / 21^{*}$ & 1/F+/PP & $312.25[2.75]$ & Scotese et al. 1984; Gibling et al. 2019 \\
\hline $\begin{array}{l}\text { Colorado, Minturn Formation, Comp.Mh/ Atokan to } \\
\text { Desmoinesian }\end{array}$ & Red beds & $0 / 111^{*}$ & $1 / 0 / \mathrm{MS}$ & $311[4]$ & Magnus \& Opdyke 1991; Itano et al., 2003. \\
\hline $\begin{array}{l}\text { Algeria, Illizi Basin, Edjeleh Fold, } \\
\text { Comp.C/Moscovian }\end{array}$ & Red beds & $0 / 32^{*}$ & $1 / \mathrm{F}+/ \mathrm{PP}$ & $311.1[4.1]$ & Derder et al. 2001 \\
\hline Algeria, Lower El Adeb Larache Fm/Moscovian & Marl, Limestone & $0 / 61^{*}$ & 1/0/PP & $311.1[4.1]$ & Henry et al. 1992 \\
\hline $\begin{array}{l}\text { Russia, Tver Oblast, River Volga/ } 25 \% \text { of e. } \\
\text { Kashirian }\end{array}$ & Red clays & $0 / 20^{+}$ & 1/0/PP & $312.65[0.15]$ & $\begin{array}{l}\text { losifidi et al. 2018; losifidi \& Mikhailova } \\
2017\end{array}$ \\
\hline Russia, Pushchino, Nara River/ e. Vereian & Brown-red clays & $0 / 14^{+}$ & 1/0/PP & $313.35[0.35]$ & $\begin{array}{l}\text { losifidi et al. 2018; losifidi \& Mikhailova, } \\
2017\end{array}$ \\
\hline S. Korea, Manhang Fm, High-T/ e. Moscovian & Red beds & $12 / 81^{*}$ & $1 / \mathrm{F}+/ \mathrm{PP}$ & $313.5[1.5]$ & Doh \& Piper 1994; Lee 2010 \\
\hline S. Korea, Hongjom Fm/ e. Moscovian & Red beds & $3 / 16^{*}$ & 1/0/PP & $313.5[1.5]$ & Kim et al. 1992; Lee 2010 \\
\hline Moscow, Rzhev layers/ 5\% of Kashirian & Red clays & $0 / 20^{+}$ & 1/0/PP & $312.1[0.1]$ & losifidi \& Mikhailova 2017 \\
\hline Algeria, Upper "Dembaba" fm/ e. Moscovian & Limestone & $0 / 113^{*}$ & $1 / F+/ P P$ & $313.5[1.5]$ & Amenna et al. 2014 \\
\hline
\end{tabular}

From Lucas, Schneider et al. (eds) The Carboniferous Timescale, Spec. Publ. Geol. Soc. Lond. 


\begin{tabular}{|c|c|c|c|c|c|}
\hline Pushchino, Nara river/ 5\% of Vereian & Red clays & $0 / 14^{+}$ & 1/0/PP & $313.4[0.1]$ & losifidi \& Mikhailova 2017 \\
\hline S. Korea, Manhang, Yobong Fms/ e. Moscovian & Red beds & $1 / 22^{*}$ & 1/F+/PP & $313.75[1.75]$ & Lee et al. 1996; Lee 2010 \\
\hline Algeria, "Hassi Bachir" Fm, Comp. C/ I. Bashkirian & Red beds & $0 / 69^{*}$ & 1/F+/PP & $314.5[2.5]$ & Derder et al. 2009; Wendt et al. 2009 \\
\hline Kyrgyzstan, West Kyrgyz Range/ Bashkirian & Red beds & $48 / 1^{*}$ & $1 / \mathrm{F}+/ \mathrm{PP}$ & $319.2[4]$ & Bazhenov et al. 2003 \\
\hline \multicolumn{6}{|c|}{ Serpukhovian- early Bashkirian not shown } \\
\hline $\begin{array}{l}\text { Kyrgyzstan, Dungurma Fm, North Tien Shan/ I. } \\
\text { Visean- Serpukhovian }\end{array}$ & Red beds & $0 / 86^{*}$ & $1 / F+/ P P$ & $329[6]$ & Bazhenov et al. 2003 \\
\hline $\begin{array}{l}\text { Borovichi, Egol'skaya group, Novgorod region/ E. } \\
\text { Venevian }\end{array}$ & $\begin{array}{l}\text { Limestones, Red } \\
\text { clays }\end{array}$ & $0 / 23^{+}$ & 1/0/PP & $330.5[0.5]$ & losifidi et al. 2018 \\
\hline $\begin{array}{l}\text { Newfoundland, Jeffrey's Village Mbr, Comp A/ } \\
\text { Brigantian }\end{array}$ & Red beds & $29 / 3^{+}$ & $1 / \mathrm{F}+/ \mathrm{PP}$ & $331[2]$ & Murthy 1985; Utting \& Giles 2008 \\
\hline $\begin{array}{l}\text { Nova Scoria, Green oaks Fm, Windsor Grp/ } \\
\text { Brigantian }\end{array}$ & Limestone, red beds & $0 / 41^{*}$ & $1 / \mathrm{F}+/ \mathrm{PP}$ & 331.25 [2.25] & Scotese et al. 1984; Giles 2009 \\
\hline $\begin{array}{l}\text { SW Ningxia, Zhongning, Chouniugou Fm, B Comp/ } \\
\text { I. Visean }\end{array}$ & Limestones & $1 / 32^{+}$ & 1/0/PP & $333.95[3.05]$ & Huang et al. 2001 \\
\hline Novgorod, Lubytino, /Aleksinian & Clastics, limestones & $6 / 10^{+}$ & 1/0/PP & $334.5[0.5]$ & losifidi et al. 2016 \\
\hline Boksitogorsk, mine no. $13 / 10 \%$ of Tulian & Brown and red clays & $0 / 3^{+}$ & 1/0/PP & $338.5[2.5]$ & Iosifidi \& Mikhailova 2017 \\
\hline $\begin{array}{l}\text { Donbass, Volnovakha, Mokrovolnovakhskaya } \\
\text { Series/ Styl'sky Stage ( e. Tulian) }\end{array}$ & Limestones & $0 / 11^{+}$ & 1/0/PP & $339.5[1.5]$ & Iosifidi et al. 2016; Davydov et al. 2012 \\
\hline Newfoundland, Spout Fall Fm, Comp A/ Arundian & Red beds & $37 / 0^{+}$ & 1/F+/PP & $343.5[0.5]$ & Murthy 1985; Gibling et al. 2019 \\
\hline $\begin{array}{l}\text { Newfoundland, Terrenceville Fm, Comp A/ } \\
\text { Tournaisian }\end{array}$ & Red beds & $12 / 28$ & 1/F0/PP & $353[6]$ & Kent 1982 \\
\hline $\begin{array}{l}\text { Nova Scotia, Horton Grp \& Cheverie Fm/ I. } \\
\text { Famennian- I. Tournaisian }\end{array}$ & Red beds & $0 / 12^{*}$ & 1/0/PP & 354 [7] & Scotese et al. 1984; Jutras et al. 2006 \\
\hline
\end{tabular}

Table 2. Studies showing polarity bias data in the early Mississippian and Pennsylvanian. $N_{n}, R_{n}=$ Number of specimens or sites with normal $\left(N_{n}\right)$ or Reverse polarity $\left(R_{n}\right)$. + Stratigraphic levels, ${ }^{*}$ specimens (in most sources it is not clear how many sites or

samples/specimens represent different stratigraphic levels). $\mathrm{Dm} / \mathrm{FT} / \mathrm{S}=$ demagnetisation method/fold test/study type. $\mathrm{D}_{\mathrm{m}}=1$, if full demagnetisation applied to all samples, with principle component or great circle extraction, $D_{m}=2$, pilot demagnetisations of simple magnetisation behaviour, with stable point averaging, or single step. $D_{m}=0$, none or temporal demagnetisation. $F+=$ fold test positive (or demonstrate pre-folding magnetisation), $\mathrm{F}-=$ fold test negative, $0=$ no fold test. $\mathrm{S}=\mathrm{PP}$ or MS for palaeopole- type sampling or magnetostratigraphic style sampling respectively. $\mathrm{Ma}=$ Million years for mid of study interval with confidence [CI] interval or like range of study (using timescale in Richards (2013) for most, but using timescale in Davydov et al. (2010), for Russian stage or Fm units as shown in their Fig. 2). I.=late, e.= early. 


\begin{tabular}{|c|c|c|c|c|c|c|}
\hline $\begin{array}{l}\text { 1.Code, } \\
\text { age (Myr } \\
\text { ago) }\end{array}$ & $\begin{array}{l}2 . \\
\pm 2 \sigma_{\mathrm{R}} \\
(\mathrm{Myr})\end{array}$ & 3. $\pm e_{\mathrm{s}}$ & 4. Location & $\begin{array}{l}\text { 5.Biostratigraphy, stratigraphy } \text { \{magnetochron } \\
\text { relative position\} }\end{array}$ & $\begin{array}{l}6 . \\
P_{\text {out }}\end{array}$ & 7. Ref. \\
\hline $\begin{array}{l}\text { n1 coal } \\
307.26\end{array}$ & 0.37 & $\begin{array}{l}10 \% \text { of } \\
\text { PE7r }\end{array}$ & Butovskaya shaft, Donets Basin & $\begin{array}{l}\text { Base Peskovian, Base } \mathrm{C}_{3} \text { a and Pr. ovoides-Praeobs. } \\
\text { Burkemensis Zone }\{\text { top of DB5r in Fig. } 1\}\end{array}$ & 0.00 & Davydov et al. 2010 \\
\hline $\begin{array}{l}\text { 01DES- } \\
362 \\
307.66\end{array}$ & 0.37 & $\begin{array}{l}10 \% \\
\text { PE7r }\end{array}$ & Dal'ny Tulkas Quarry, S. Urals & $\begin{array}{l}\text { Upper Myachkovian, } 70 \% \text { thro Ng. roundyi CZ, }\{76 \% \\
\text { into PE7r }\}\end{array}$ & 0.00 & $\begin{array}{l}\text { Schmitz \& Davydov } \\
2012\end{array}$ \\
\hline $\begin{array}{l}06 \text { US0-2.0 } \\
308.0\end{array}$ & 0.37 & $\begin{array}{l}15 \% \\
\text { PE7r }\end{array}$ & Usolka section, S. Urals & mid Myachkovian $\{59 \%$ into PE7r $\}$ & 0.01 & $\begin{array}{l}\text { Schmitz \& Davydov } \\
2012\end{array}$ \\
\hline $\begin{array}{l}\text { 01DES- } \\
481 \\
308.36\end{array}$ & 0.38 & $\begin{array}{l}15 \% \\
\text { PE7r }\end{array}$ & Usolka section, S. Urals & mid Myachkovian $\{58 \%$ into PE7r $\}$ & 0.01 & $\begin{array}{l}\text { Schmitz \& Davydov } \\
2012\end{array}$ \\
\hline $\begin{array}{l}\text { 01DES- } \\
351 \\
308.5\end{array}$ & 0.36 & $\begin{array}{l}10 \% \\
\text { PE7r }\end{array}$ & Dal'ny Tulkas Quarry, S. Urals & $\begin{array}{l}\text { Lower Myachkovian }\{20 \% \text { into } \mathrm{PE} 7 \mathrm{r}\} \text {, base of } \mathrm{Ng} \text {. } \\
\text { roundyi CZ }\end{array}$ & 0.01 & $\begin{array}{l}\text { Schmitz \& Davydov } \\
2012\end{array}$ \\
\hline $\begin{array}{l}\text { m3 coal } \\
310.55\end{array}$ & 0.37 & $\begin{array}{l}10 \% \text { of } \\
\text { PE6r }\end{array}$ & Zasyadko Shaft, Donets Basin & 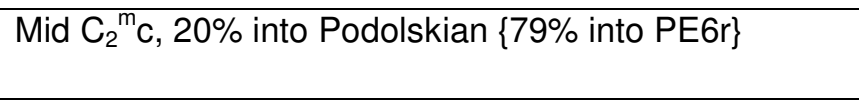 & 0.01 & Davydov et al. 2010 \\
\hline $\begin{array}{l}\text { 13(a) coal } \\
312.01\end{array}$ & 0.37 & $\begin{array}{l}75 \% \text { of } \\
\text { PE6n.2n }\end{array}$ & $\begin{array}{l}\text { Krasnolimanskaya Shaft, Donets } \\
\text { Basin }\end{array}$ & 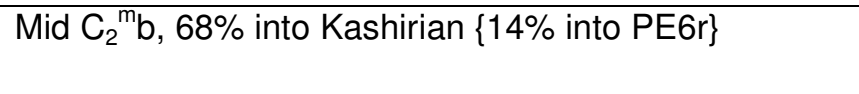 & 0.01 & Davydov et al. 2010 \\
\hline $\begin{array}{l}13(b) \text { coal } \\
312.18\end{array}$ & 0.37 & $\begin{array}{l}75 \% \text { of } \\
\text { PE6n.2n }\end{array}$ & $\begin{array}{l}\text { Zdanovskaya Shaft, Donets } \\
\text { Basin }\end{array}$ & 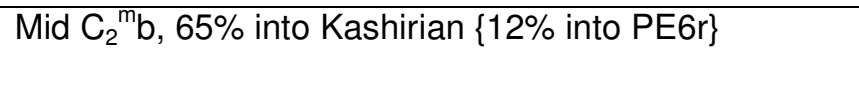 & 0.01 & Davydov et al. 2010 \\
\hline $\begin{array}{l}11 \text { coal } \\
312.23\end{array}$ & 0.37 & $\begin{array}{l}20 \% \text { of } \\
\text { PE6n.1r }\end{array}$ & Kirov Shaft, Donets Basin & $\begin{array}{l}\text { Base } \mathrm{C}_{2}{ }^{\mathrm{m}} \mathrm{b} \text {, little above L1 in Fig. 1, } 10 \% \text { into } \\
\text { Mar'evsky }\{50 \% \text { into PE6n.1r }\}\end{array}$ & 0.01 & Davydov et al. 2010 \\
\hline $\begin{array}{l}\text { k7 coal } \\
313.16\end{array}$ & 0.37 & $\begin{array}{l}20 \% \\
\text { PE5r }\end{array}$ & $\begin{array}{l}\text { Pereval'skaya Shaft, Donets } \\
\text { Basin }\end{array}$ & Upper $\mathrm{C}_{2}^{\mathrm{m}} \mathrm{a}, 75 \%$ into Kamensky $\{96 \%$ into PE5r $\}$ & 0.01 & Davydov et al. 2010 \\
\hline $\begin{array}{l}\text { k3 coal } \\
314.40\end{array}$ & 0.37 & $\begin{array}{l}20 \% \\
\text { PE5r }\end{array}$ & $\begin{array}{l}\text { Pereval'skaya Shaft, Donets } \\
\text { Basin }\end{array}$ & Base $\mathrm{C}_{2}{ }^{\mathrm{m}} \mathrm{a}$, base Kamensky $\{56 \%$ into PE5r $\}$ & 0.13 & Davydov et al. 2010 \\
\hline $\begin{array}{l}\text { Z1 } \\
\text { Tonstein } \\
313.78\end{array}$ & 0.38 & $\begin{array}{l}15 \% \text { of } \\
\text { PE5r }\end{array}$ & $\begin{array}{l}\text { Furst Leopold Coal Mine, Ruhr } \\
\text { Basin, Germany }\end{array}$ & $\begin{array}{l}10-12 \text { m beneath the Ägir marine band. So in topmost } \\
\text { Duckmantian }\{30 \% \text { in PE5r }\}\end{array}$ & 0.12 & Pointon et al. 2012 \\
\hline $\begin{array}{l}\text { Bed } 32 \\
317.54\end{array}$ & 0.38 & $\begin{array}{l}20 \% \\
\text { PE4n }\end{array}$ & Kijuch section, S. Urals & $\begin{array}{l}\text { Cheremshankian, } 75 \% \text { into Asatauian- Tashastian } \\
\text { interval }\{10 \% \text { into PE } 4 \mathrm{r}\}\end{array}$ & 0.01 & $\begin{array}{l}\text { Schmitz \& Davydov } \\
2012\end{array}$ \\
\hline $\begin{array}{l}\text { T75 } \\
317.63\end{array}$ & 0.39 & $\begin{array}{l}15 \% \\
\text { PE4n }\end{array}$ & Zwartberg Coal Mine, Belgium, & $\begin{array}{l}\text { Tonstein } 75, \text { mid RA miospore zone, } 73 \% \text { into } \\
\text { Langsettian. }\{74 \% \text { into PE } 4 n\}\end{array}$ & 0.01 & $\begin{array}{l}\text { Pointon et al. 2012, } \\
\text { Paproth et al. } 1983\end{array}$ \\
\hline $\begin{array}{l}\text { Bed } 9 \\
318.63\end{array}$ & 0.40 & $\begin{array}{l}10 \% \\
\text { PE3n }\end{array}$ & Kijuch section, S. Urals & $\begin{array}{l}\text { Prikamian, } 60 \% \text { into Askynbashian, }\{70 \% \text { into } \\
\text { PE3n.2n\}; }\end{array}$ & 0.01 & $\begin{array}{l}\text { Schmitz \& Davydov } \\
2012\end{array}$ \\
\hline
\end{tabular}

From Lucas, Schneider et al. (eds) The Carboniferous Timescale, Spec. Publ. Geol. Soc. Lond. 


\begin{tabular}{|c|c|c|c|c|c|c|}
\hline $\begin{array}{l}\text { Bed } 2 \\
319.09\end{array}$ & 0.38 & $\begin{array}{l}25 \% \\
\text { PE3n }\end{array}$ & Kijuch section, S. Urals & Prikamian, $10 \%$ into Askynbashian, $\{45 \%$ into PE3n $\}$ & 0.01 & $\begin{array}{l}\text { Schmitz \& Davydov } \\
2012\end{array}$ \\
\hline $\begin{array}{l}\text { B9 } \\
324.54\end{array}$ & 0.46 & $\begin{array}{l}25 \% \text { of } \\
\text { MI9n }\end{array}$ & $\begin{array}{l}\text { Oakenclough Brook, Pennines } \\
\text { Basin, England }\end{array}$ & $\begin{array}{l}\text { Namurian E2b2 ammonoid subzone, } 50 \% \text { into } \\
\text { Arnsbergian }\{50 \% \text { into MI9n }\}\end{array}$ & 0.01 & Pointon et al. 2012 \\
\hline $\begin{array}{l}\mathrm{GP}-1 \\
325.64\end{array}$ & 0.40 & $\begin{array}{l}100 \% \\
\text { MI8r.1n }\end{array}$ & $\begin{array}{l}\text { Julius Fučík Mine, Upper Silesia } \\
\text { Basin, Czech Rep }\end{array}$ & $\begin{array}{l}\text { 35\% into E2a Zone, Jaklovec Mbr, coal 365, Gabriela, } \\
14 \% \text { into Arnsbergian }\{80 \% \text { into Ml8r\} }\end{array}$ & 0.01 & Jirasek et al. 2018 \\
\hline $\begin{array}{l}\text { GP-2 } \\
325.58\end{array}$ & 0.45 & $\begin{array}{l}100 \% \\
\text { MI8r.1n }\end{array}$ & $\begin{array}{l}\text { Julius Fučík Mine, Upper Silesia } \\
\text { Basin, Czech Rep }\end{array}$ & $\begin{array}{l}30 \% \text { into E2a Zone, Jaklovec Mbr, coal 335, } \\
\text { Eleonora, } 14 \% \text { into Arnsbergian }\{82 \% \text { into Ml8r }\}\end{array}$ & 0.01 & Jirasek et al. 2018 \\
\hline $\begin{array}{l}\text { GP-4 } \\
327.00\end{array}$ & 0.49 & $\begin{array}{l}100 \% \\
\text { Ml8r.1n }\end{array}$ & $\begin{array}{l}\text { Zárubek Mine, Upper Silesia } \\
\text { Basin, Czech Rep }\end{array}$ & $\begin{array}{l}90 \% \text { into E1c Zone, Upper Hrosov Mbr, coal 252, } \\
\text { Flora, } 97 \% \text { into Pendleian \{base of Ml8r.2r\} }\end{array}$ & 0.00 & Jirasek et al. 2018 \\
\hline $\begin{array}{l}\text { Karel Coal } \\
327.58\end{array}$ & 0.39 & $\begin{array}{l}15 \% \text { of } \\
\text { Ml8r.1r }\end{array}$ & $\begin{array}{l}\text { Staric } 2 \text { core, Upper Silesia } \\
\text { Basin, Czech Rep. }\end{array}$ & $\begin{array}{l}15 \% \text { into E1c zone, } 80 \% \text { into Pendleian, Coal } \\
106 \text {,close to base Hrusov Mbr of Ostrava Fm }\{16 \% \\
\text { into MI8r\} }\end{array}$ & 0.01 & $\begin{array}{l}\text { Gastaldo et al. 2009, } \\
\text { Jirasek et al. } 2018\end{array}$ \\
\hline $\begin{array}{l}\text { MOW } \\
327.35\end{array}$ & 0.39 & $\begin{array}{l}15 \% \text { of } \\
\text { MI8r.1r }\end{array}$ & $\begin{array}{l}\text { Main Ostrava Whetstone tuffite, } \\
\text { Upper Silesia Basin, Czech Rep. }\end{array}$ & $\begin{array}{l}12 \% \text { into E1c Zone, } 78 \% \text { into Pendleian, at base of } \\
\text { Hrusov Mbr of Ostrava Fm }\{13 \% \text { into Ml8r }\}\end{array}$ & 0.01 & $\begin{array}{l}\text { Gastaldo et al. } 2009 \text {, } \\
\text { Jirasek et al. } 2018\end{array}$ \\
\hline $\begin{array}{l}\text { C11 coal } \\
328.14\end{array}$ & 0.40 & $\begin{array}{l}15 \% \text { of } \\
\text { MI8n }\end{array}$ & $\begin{array}{l}\text { Yuzhno-Donbasskaya, Ugledar, } \\
\text { Donets Basin, Ukraine }\end{array}$ & $\begin{array}{l}\text { Middle } \mathrm{C}_{1}{ }_{\mathrm{g} 2} \text { zone- Foraminifera, Betpakodiscus } \\
\text { cornuspiroides, lower Steshevian \{base MI8n.1r\} }\end{array}$ & 0.01 & $\begin{array}{l}\text { Davydov et al. } 2010 \text {, } \\
\text { Somerville } 2008\end{array}$ \\
\hline $\begin{array}{l}\text { Ludmilla } \\
\text { coal } \\
328.48\end{array}$ & 0.41 & $\begin{array}{l}15 \% \text { of } \\
\text { MI8n }\end{array}$ & $\begin{array}{l}\text { Staric } 2 \text { core, Upper Silesia } \\
\text { Basin, Czech Rep. }\end{array}$ & $\begin{array}{l}50 \% \text { into E1B Zone, } 50 \% \text { into Pendleian, Coal 043, } \\
\text { Petrkovice Mbr of Ostrava Fm \{base Ml8n\} }\end{array}$ & 0.01 & $\begin{array}{l}\text { Gastaldo et al. 2009, } \\
\text { Jirasek et al. } 2018\end{array}$ \\
\hline $\begin{array}{l}\text { W13 } \\
332.5\end{array}$ & 0.40 & $\begin{array}{l}50 \% \text { of } \\
\mathrm{Ml5r}\end{array}$ & $\begin{array}{l}\text { Watrisse Quarry, Anhée Sud, } \\
\text { Belgium }\end{array}$ & $\begin{array}{l}\text { Lower part of Anhee Fm, in foram. zone MFZ14 (H. } \\
\text { bradyana interval zone), late Asbian. }\{\text { base MI5r\} }\end{array}$ & 0.01 & $\begin{array}{l}\text { Pointon et al. } 2014 ; \\
\text { Somerville } 2008\end{array}$ \\
\hline $\begin{array}{l}\text { 02VD-0 } \\
333.87\end{array}$ & 0.39 & $\begin{array}{l}15 \% \text { of } \\
\text { MI5n }\end{array}$ & $\begin{array}{l}\text { Base Bed 21-8, Verkhnyaya } \\
\text { Kardailovka, S. Urals }\end{array}$ & $\begin{array}{l}\text { Guisiken Fm, base Mikhailovian, } 40 \% \text { into } L . \\
\text { mononodosa Zone, near the base of the } E \text {. } \\
\text { assymetrica foram. Zone (foram. zone MFZ14, mid } \\
\text { Asbian \{base MI5n.1r\} }\end{array}$ & 0.01 & $\begin{array}{l}\text { Schmitz \& Davydov } \\
\text { 2012; Sevastopulo \& } \\
\text { Barham } 2014\end{array}$ \\
\hline $\begin{array}{l}\text { W18 } \\
335.59\end{array}$ & 0.44 & $\begin{array}{l}100 \% \text { of } \\
\text { Ml4r.2r }\end{array}$ & $\begin{array}{l}\text { Watrisse Quarry, Anhée Sud, } \\
\text { Belgium }\end{array}$ & $\begin{array}{l}15 \mathrm{~m} \text { above base Bonne River Fm, early Asbian, } 20 \% \\
\text { into MFZ13 }\{\text { base of Ml4r.1n\} }\end{array}$ & 0.00 & Pointon et al. 2014; \\
\hline \multicolumn{7}{|c|}{ SHRIMP dates used shown below } \\
\hline 320.7 & 3.0 & $\begin{array}{l}20 \% \\
\text { PE1r }\end{array}$ & $\begin{array}{l}\text { Rocky Creek Syncline, E. } \\
\text { Australia }\end{array}$ & $\begin{array}{l}\text { Upper Clifden Fm, Peri and Easton Arms Rhylolites } \\
\text { combined (CL2) }\{60 \% \text { into PE1r.1r }\}\end{array}$ & 0.01 & $\begin{array}{l}\text { Fig. 6; Opdyke et al. } \\
2000\end{array}$ \\
\hline 322.4 & 2.8 & $\begin{array}{l}20 \% \\
\text { PE1n }\end{array}$ & $\begin{array}{l}\text { Rocky Creek Syncline, } \\
\text { Pinnacles section, E. Australia }\end{array}$ & $\begin{array}{l}\text { mid Clifden Fm, Wanganui Andesite (CL10) }\{50 \% \text { into } \\
\text { PE1n\} }\end{array}$ & 0.00 & $\begin{array}{l}\text { Fig. 6; Opdyke et al. } \\
2000\end{array}$ \\
\hline 325.5 & 3.2 & $\begin{array}{l}20 \% \text { of } \\
\text { MI9r }\end{array}$ & $\begin{array}{l}\text { Rocky Creek Syncline, } \\
\text { Pinnacles section, E. Australia }\end{array}$ & mid Clifden Fm, unnamed dacite\{base PE1n\} & 0.01 & $\begin{array}{l}\text { Fig. 6; Opdyke et al. } \\
2000\end{array}$ \\
\hline 324.5 & 3.2 & $\begin{array}{l}20 \% \\
\mathrm{MI} 9 \mathrm{r}\end{array}$ & $\begin{array}{l}\text { Rocky Creek Syncline, E. } \\
\text { Australia }\end{array}$ & Upper part of Ermelo Pyroclastics $\{50 \%$ into MI9r $\}$ & 0.01 & $\begin{array}{l}\text { Fig. 6; Opdyke et al. } \\
2000\end{array}$ \\
\hline
\end{tabular}

From Lucas, Schneider et al. (eds) The Carboniferous Timescale, Spec. Publ. Geol. Soc. Lond. 
Table 3. Carboniferous radioisotopic dates used to constrain the GPTS. Column 1: Analysis code and date (in Ma). Column 2: $\pm 2 \sigma_{R}=$ two-sigma error on age (includes tracer calibration, and ${ }^{238} U$ decay constant, except for SHRIMP dates). Column 3: $\pm e_{s}=$ estimated stratigraphic error in placing the date onto the magnetostratigraphy in percent of magnetozone widths. Column 4: section name, location. Column 5: Stratigraphic age or location, $\{.\}=$. correlated chron position of date (see Figs. 16 and 17).

Column 6: $P_{\text {out }}$, probability (0 to 1.0 range) the date is an outlier (from Bchron). The low values here all indicate none are likely outliers'. Column 7: source reference for the radioisotopic and age information. PE7r length here is to top of Bol'shaya Kalitva section in Fig. 1. 


\begin{tabular}{|c|c|c|c|c|c|c|c|c|c|}
\hline Chron & Age (Ma) & $\begin{array}{c}\text { Chron } \\
\text { duration } \\
(\mathrm{Ma})\end{array}$ & $\begin{array}{c}\mathrm{C}_{95} \\
(\mathrm{Ma})\end{array}$ & $\begin{array}{c}\sigma_{\mathrm{T}} \\
(\mathrm{Ka})\end{array}$ & Chron & $\begin{array}{c}\text { Age } \\
\text { (Ma) }\end{array}$ & $\begin{array}{l}\text { Chron } \\
\text { duration } \\
\text { (Ma) }\end{array}$ & $\begin{array}{c}\mathrm{C}_{95} \\
(\mathrm{Ma})\end{array}$ & $\begin{array}{c}\sigma_{\mathrm{T}} \\
(\mathrm{Ka})\end{array}$ \\
\hline C1r.1r & 298.69 & $0.73^{\mathrm{H}}$ & 0.37 & 123 & Ml8r.2r & 326.84 & 1.55 & 0.39 & - \\
\hline C1n & 298.77 & $0.081^{\mathrm{H}}$ & 0.37 & 140 & MI8r.1n & 327.05 & 0.17 & 0.35 & - \\
\hline PE8r & 305.1 & $\sim 6.3^{\mathrm{a}}$ & - & - & MI8r.1r & 327.68 & 0.66 & 0.32 & 144 \\
\hline PE8nB & $\sim 305.23$ & $\sim 0.13^{\mathrm{a}}$ & - & - & MI8n.2n & 327.93 & 0.22 & 0.35 & - \\
\hline PE7r & 309.41 & $\sim 4.2^{\mathrm{a}}$ & 0.74 & - & MI8n.1r & 328.12 & 0.18 & 0.33 & - \\
\hline PE7n & 309.85 & 0.23 & 0.73 & - & MI8n.1n & 328.53 & 0.46 & 0.36 & 80 \\
\hline PE6r & 312.17 & 2.00 & 0.27 & - & $\mathrm{Ml7r}$ & 329.18 & 1.32 & 0.84 & - \\
\hline PE6n.2n & 312.24 & 0.067 & 0.26 & - & MI7n.2n & 329.29 & 0.12 & 0.87 & 15 \\
\hline PE6n.1r & 312.63 & 0.54 & 0.37 & 123 & MI7n.1r & 329.60 & 0.40 & 0.99 & - \\
\hline PE6n.1n & 312.70 & 0.063 & 0.38 & 74 & MI7n.1n & 329.75 & 0.15 & 1.00 & - \\
\hline PE5r & 315.13 & 3.30 & 1.07 & 8 & MI6r.2r & 330.56 & 0.75 & 1.07 & - \\
\hline PE5n & 315.34 & 0.16 & 1.10 & 29 & MI6r.1n & 330.80 & 0.23 & 1.07 & - \\
\hline PE4r & 317.46 & 1.17 & 0.29 & 41 & MI6r.1r & 331.44 & 0.38 & 0.97 & 25 \\
\hline PE4n.2n & 317.58 & 0.13 & 0.29 & 27 & MI6n.2n & 331.67 & 0.16 & 0.92 & 3 \\
\hline PE4n.1r & 317.69 & 0.16 & 0.32 & 0 & MI6n.1r & 331.89 & 0.13 & 0.84 & 19 \\
\hline PE4n.1n & 317.94 & 0.33 & 0.38 & - & MI6n.1n & 332.06 & 0.10 & 0.76 & 5 \\
\hline PE3r.2r & 318.37 & 0.40 & 0.39 & 50 & $\mathrm{Ml5r}$ & 332.601 & 0.38 & 0.39 & 18 \\
\hline PE3r.1n & 318.39 & 0.02 & 0.39 & 37 & MI5n.2n & 333.38 & 0.88 & 0.50 & 286 \\
\hline PE3r.1r & 318.60 & 0.15 & 0.33 & 35 & MI5n.1r & 333.79 & 0.39 & 0.44 & 218 \\
\hline PE3n.2n & 318.80 & 0.21 & 0.33 & 76 & MI5n.1n & 334.21 & 0.73 & 0.61 & 239 \\
\hline PE3n.1r & 318.85 & 0.045 & 0.33 & 86 & Ml4r.4r & 334.48 & 0.23 & 0.66 & - \\
\hline PE3n.1n & 319.72 & 1.58 & 0.80 & - & MI4r.3n & 334.70 & 0.18 & 0.66 & - \\
\hline PE2r & 319.78 & 0.10 & 0.84 & 41 & MI4r.3r & 335.079 & 0.25 & 0.62 & 26 \\
\hline PE2n & 320.49 & 0.86 & 1.12 & - & MI4r.2n & 335.19 & 0.082 & 0.61 & 5 \\
\hline PE1r.2r & 321.10 & 0.59 & 1.16 & - & MI4r.2r & 335.42 & 0.14 & 0.47 & 9 \\
\hline PE1r.1n & 321.16 & 0.06 & 1.16 & - & MI4r.1n & 335.57 & 0.14 & 0.41 & 16 \\
\hline PE1r.1r & 322.32 & 0.91 & 1.03 & 16 & MI4r.1r & $\sim 336^{\mathrm{F}}$ & $\sim 0.43$ & - & - \\
\hline PE1n & 323.59 & 0.98 & 0.76 & 28 & $\mathrm{Ml}_{4} \mathrm{n}_{\mathrm{B}}$ & $\sim 338.2^{F}$ & $\sim 2.2$ & - & - \\
\hline MI9r & 324.07 & 0.35 & 0.65 & 196 & $\mathrm{MIJr}_{\mathrm{B}}$ & $\sim 340^{F}$ & $\sim 1.8$ & - & - \\
\hline MI9n.3n & 324.76 & 0.62 & 0.43 & - & $M I 3 n_{B}$ & $\sim 342^{r}$ & $\sim 2$ & - & - \\
\hline MI9n.2r & 324.80 & 0.051 & 0.44 & - & $\mathrm{MI}^{2} \mathrm{r}_{\mathrm{B}}$ & $\sim 343^{F}$ & $\sim 1$ & - & - \\
\hline MI9n.2n & 324.94 & 0.17 & 0.47 & - & $\mathrm{Ml} 2 \mathrm{n}_{\mathrm{B}}$ & $\sim 349^{r}$ & $\sim 6$ & - & - \\
\hline MI9n.1r & 325.04 & 0.11 & 0.48 & - & $\mathrm{Ml1r}_{\mathrm{B}}$ & $\sim 354.7^{\mp}$ & $\sim 5.7$ & - & - \\
\hline MI9n.1n & 325.19 & 0.12 & 0.48 & 131 & Ml1n $_{B}$ & $\sim 357.5^{\mathrm{S}}$ & $\sim 2.8$ & - & - \\
\hline
\end{tabular}

Table 4. Ages of Carboniferous magnetochron bases and durations. $\mathrm{C}_{95}: 95 \%$ Highest posterior density intervals on the chron age, estimated using Bchron (shown in Figs. 18, 19). $\sigma_{\mathrm{T}}$ : standard deviation of the chron position in the sections for the chron (from the optimisation method), scaled by the duration of the optimised chron. $\sigma_{\mathrm{T}}$ is a measure of the uncertainty in defining the chron position in the optimised composite. ${ }^{\text {a }}$ Based on base of subcrassulus Zone from Davydov et al. (2012), and average duration of PE7n, PE6n.2n and PE6n.1n. F estimated from Fig. 15. ${ }^{\mathrm{H}}$ from Hounslow \& Balabanov (2018). ${ }^{\mathrm{S}}$ based on the base of the sandbergi Zone from Davydov et al. (2012). 


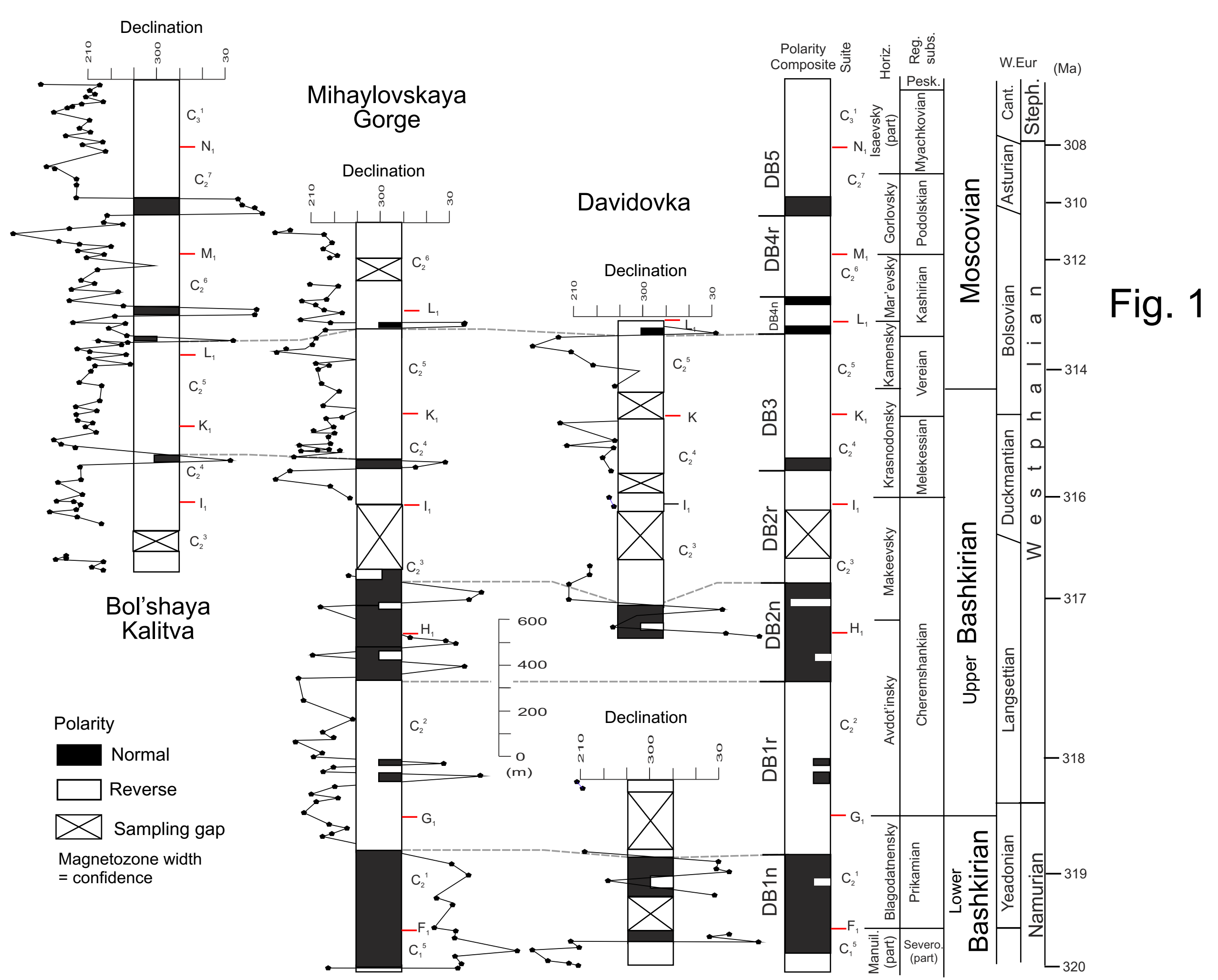


Fig. 2

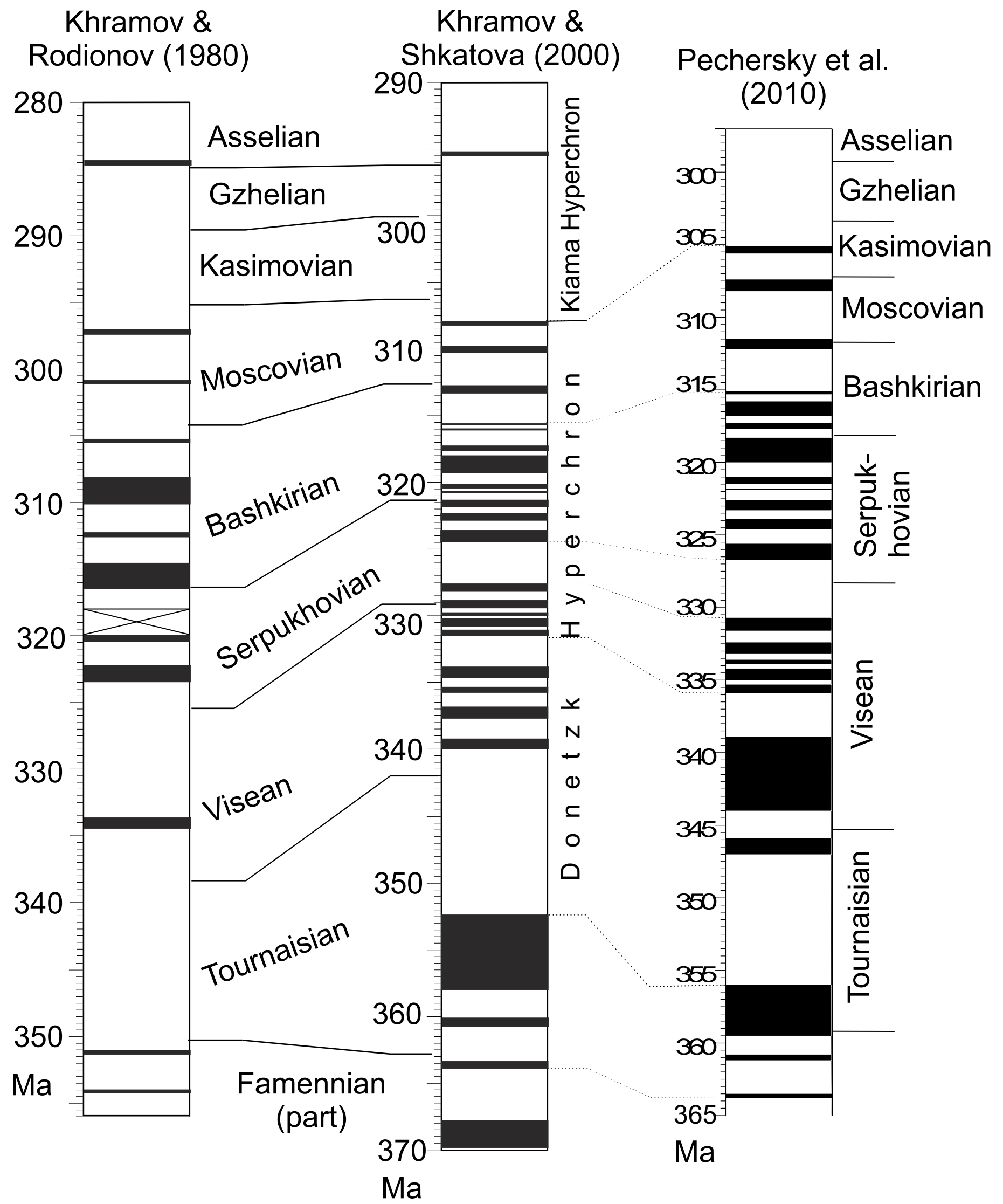




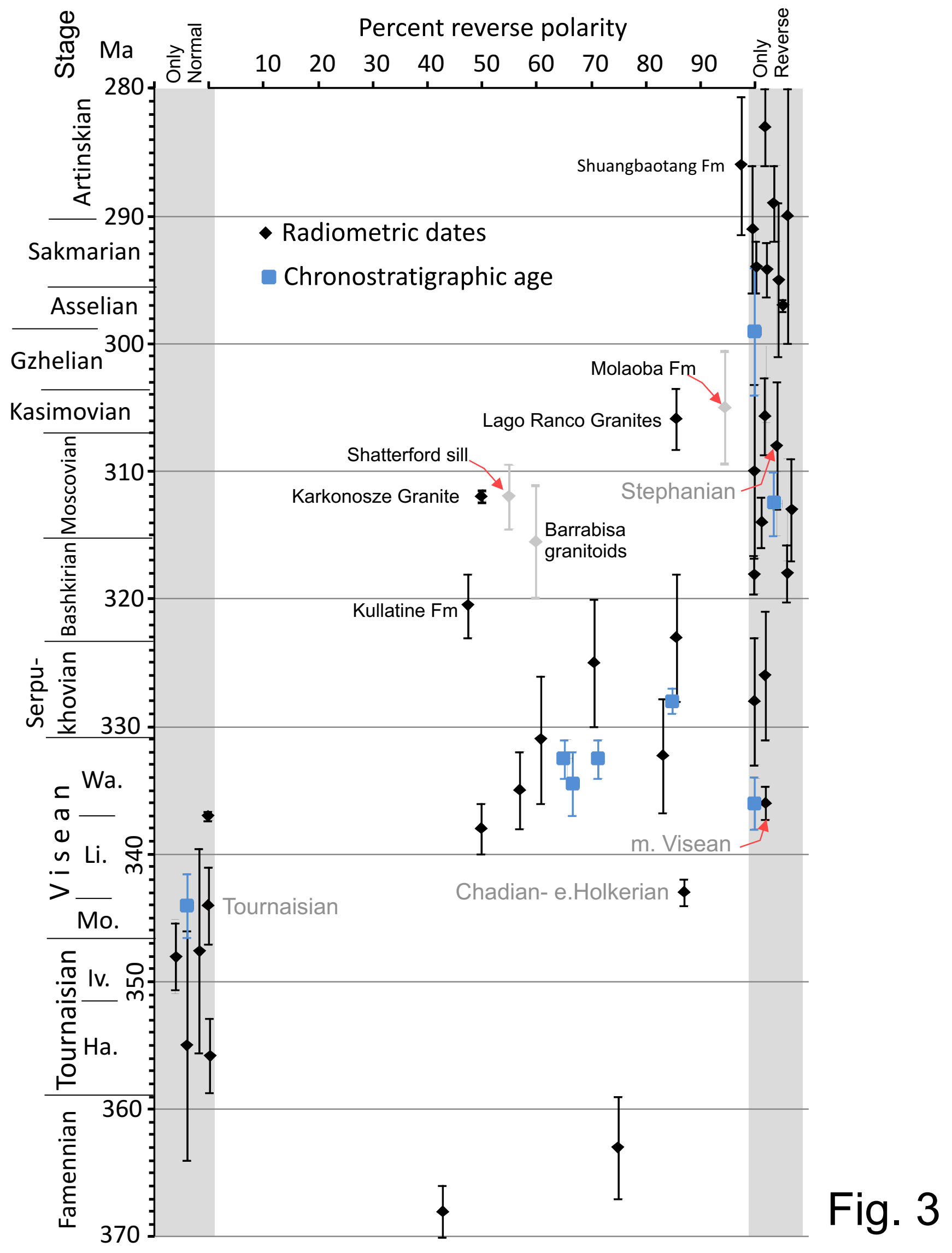




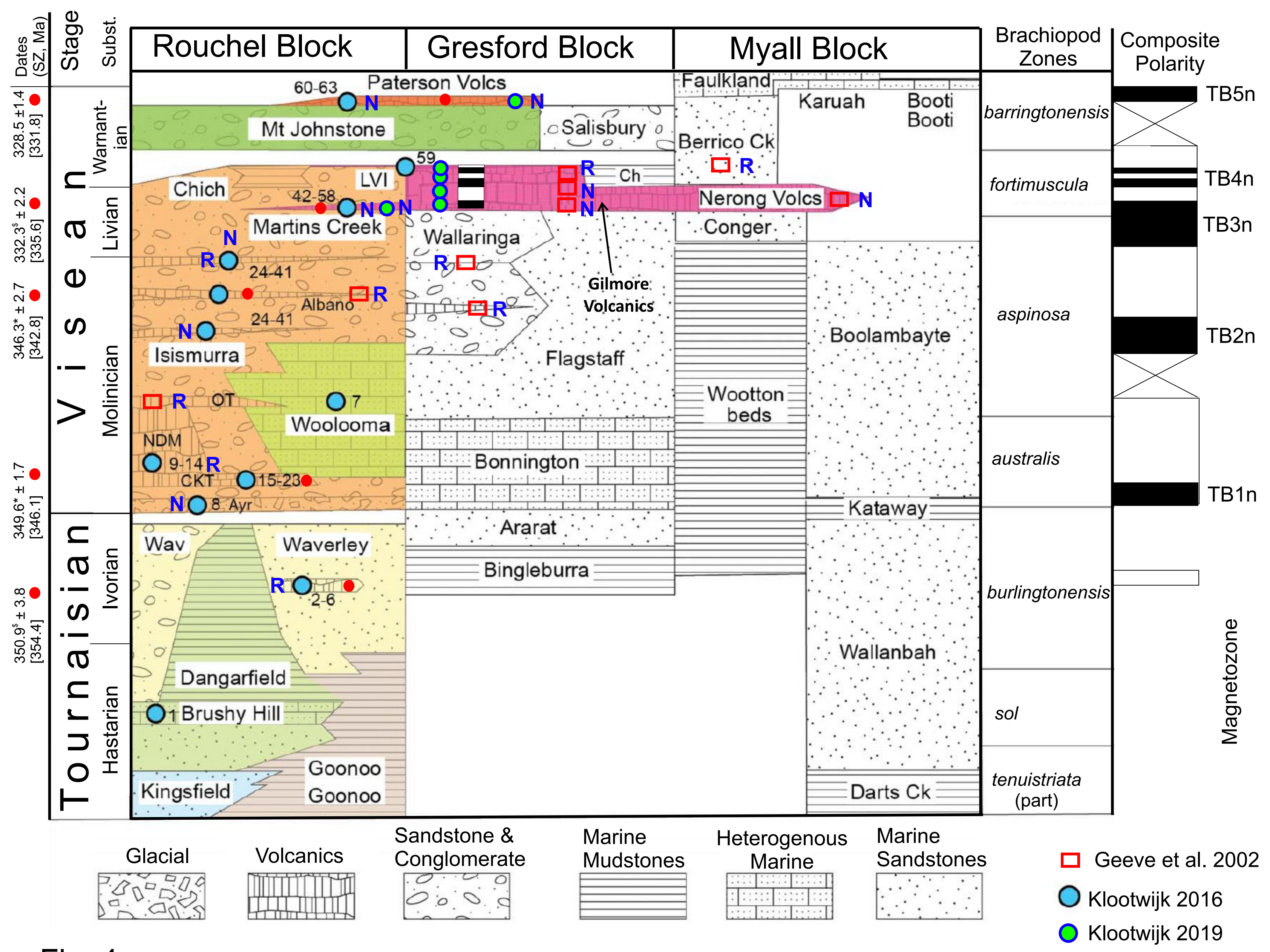

Fig. 4 


\section{Rocky Creek Syncline}

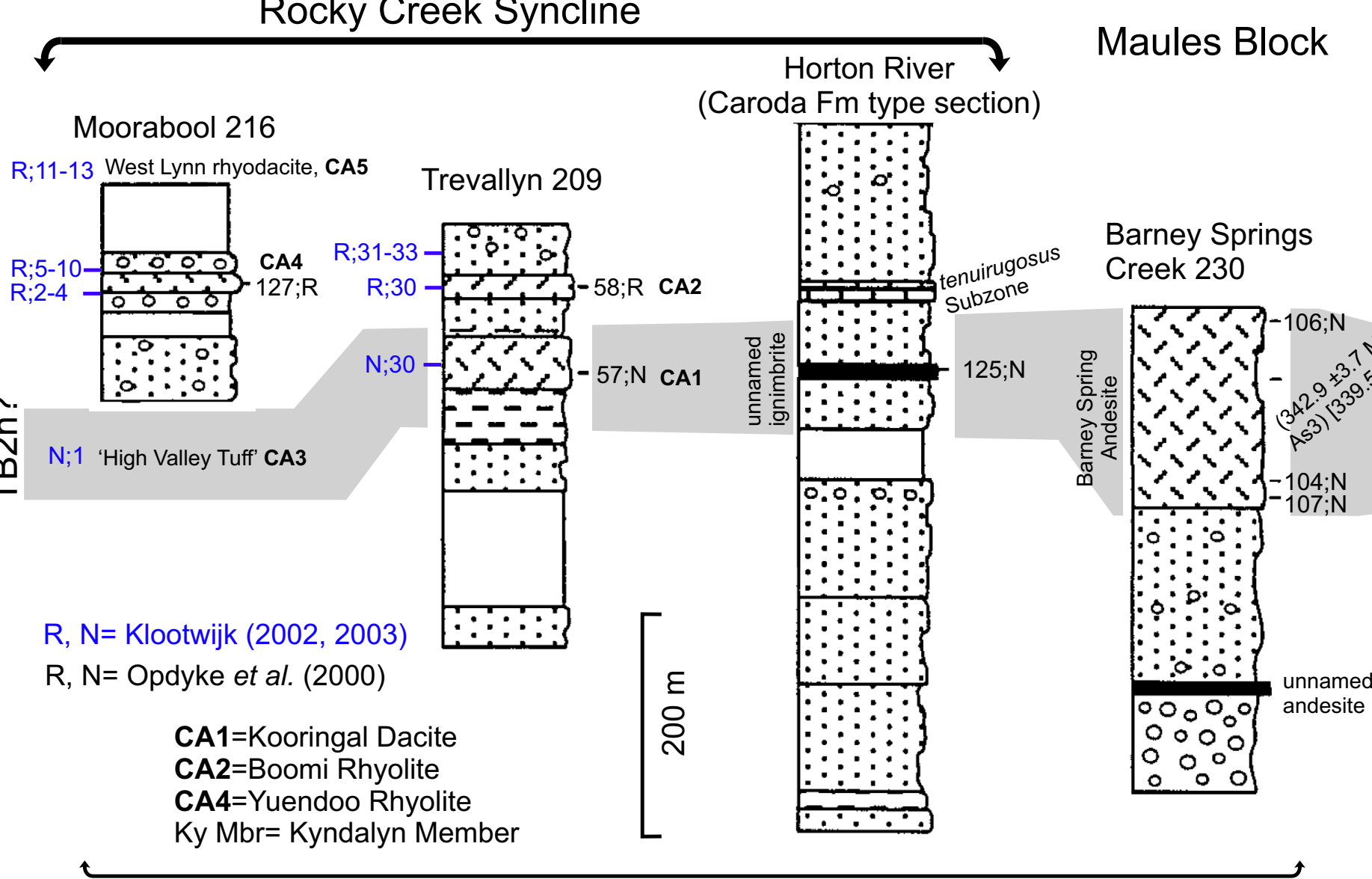

Caroda Formation
Werrie Syncline

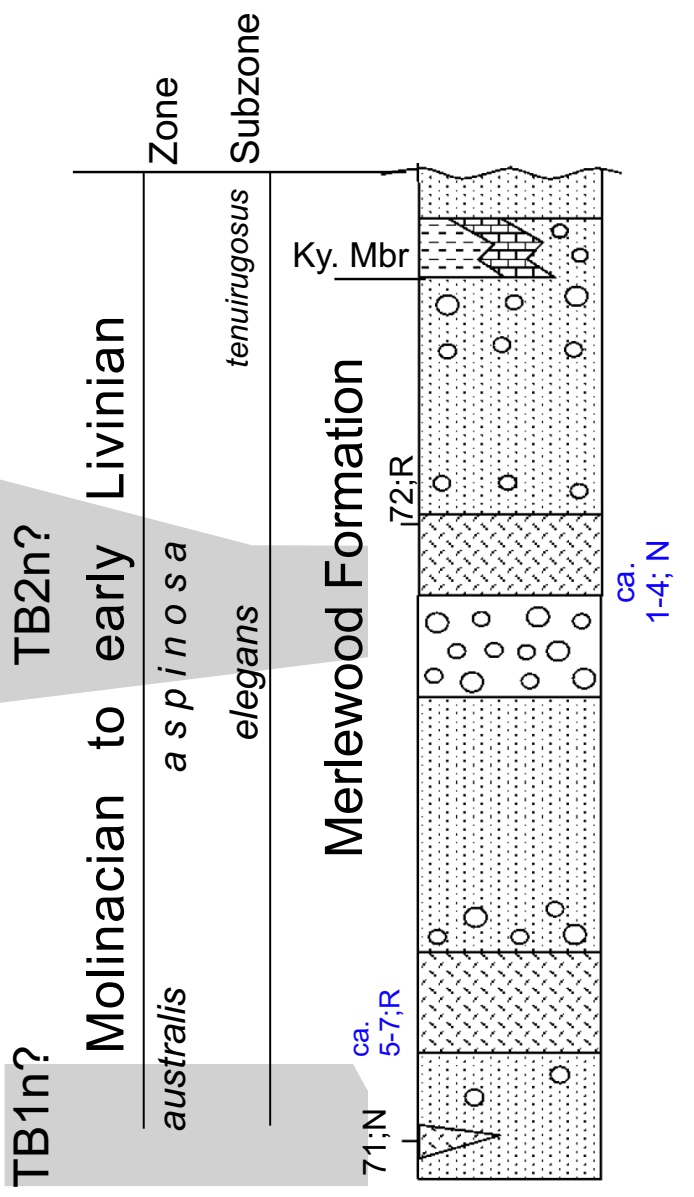

Fig. 5 


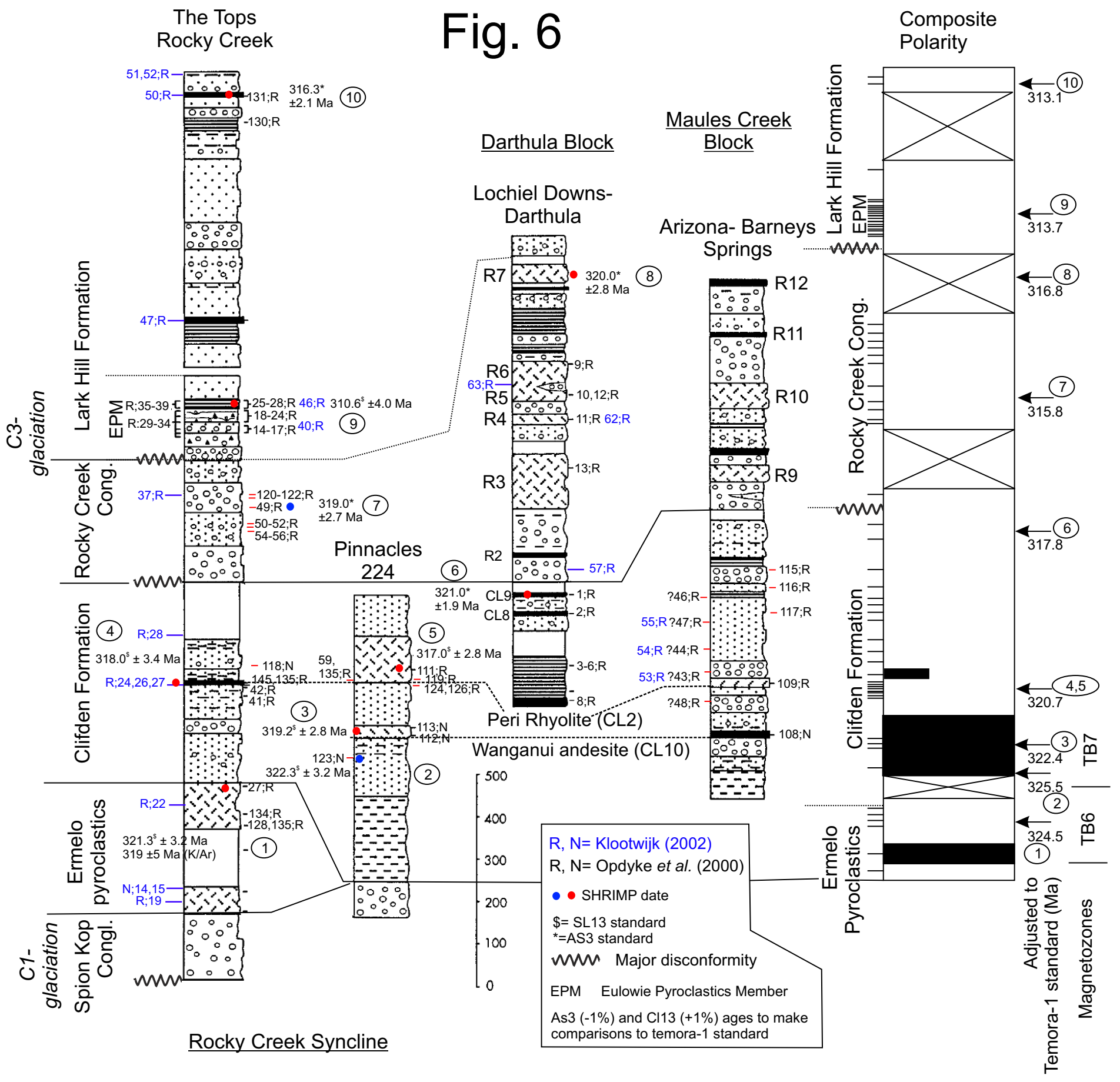




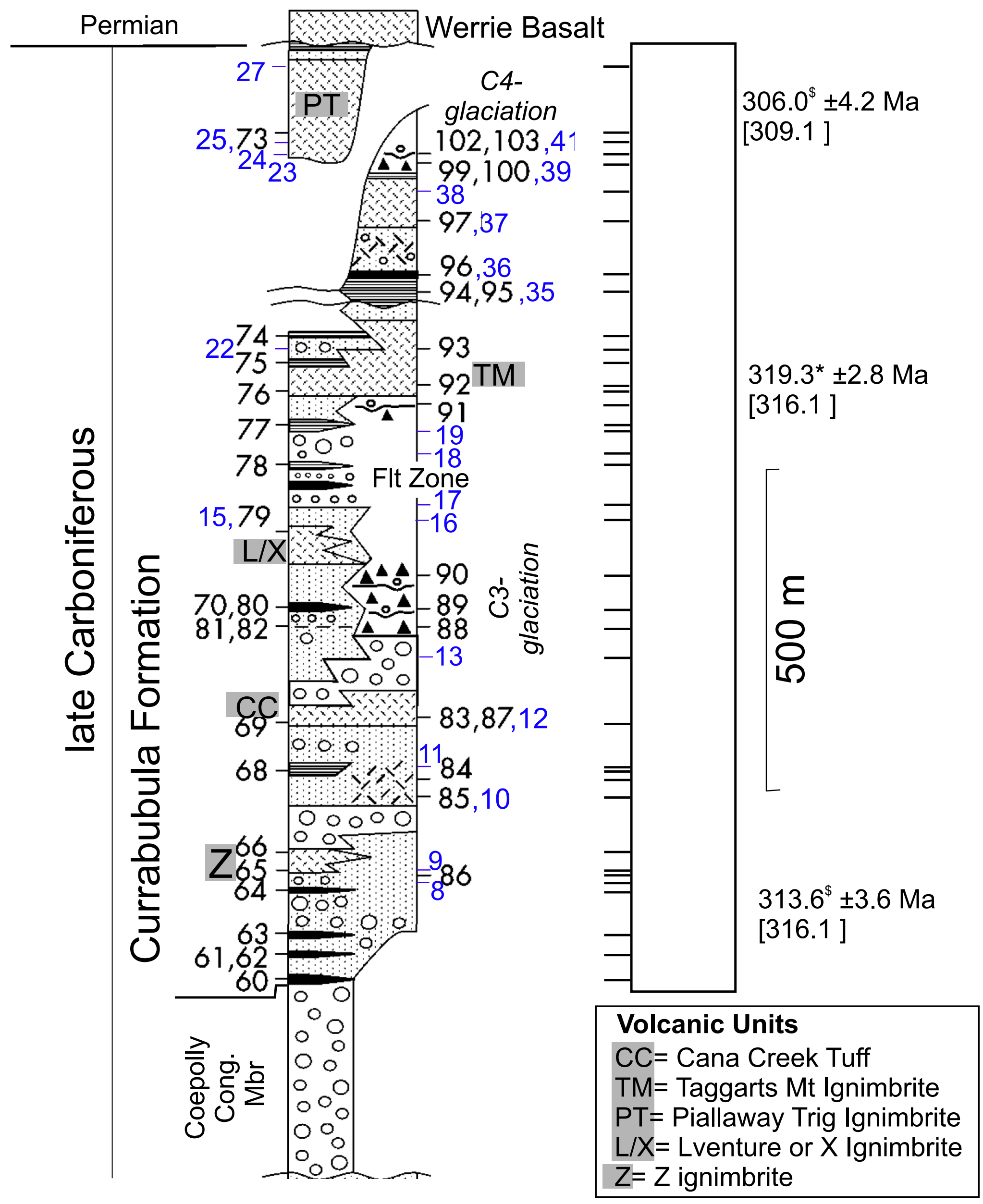

Fig. 7 


\section{Fig. 8}

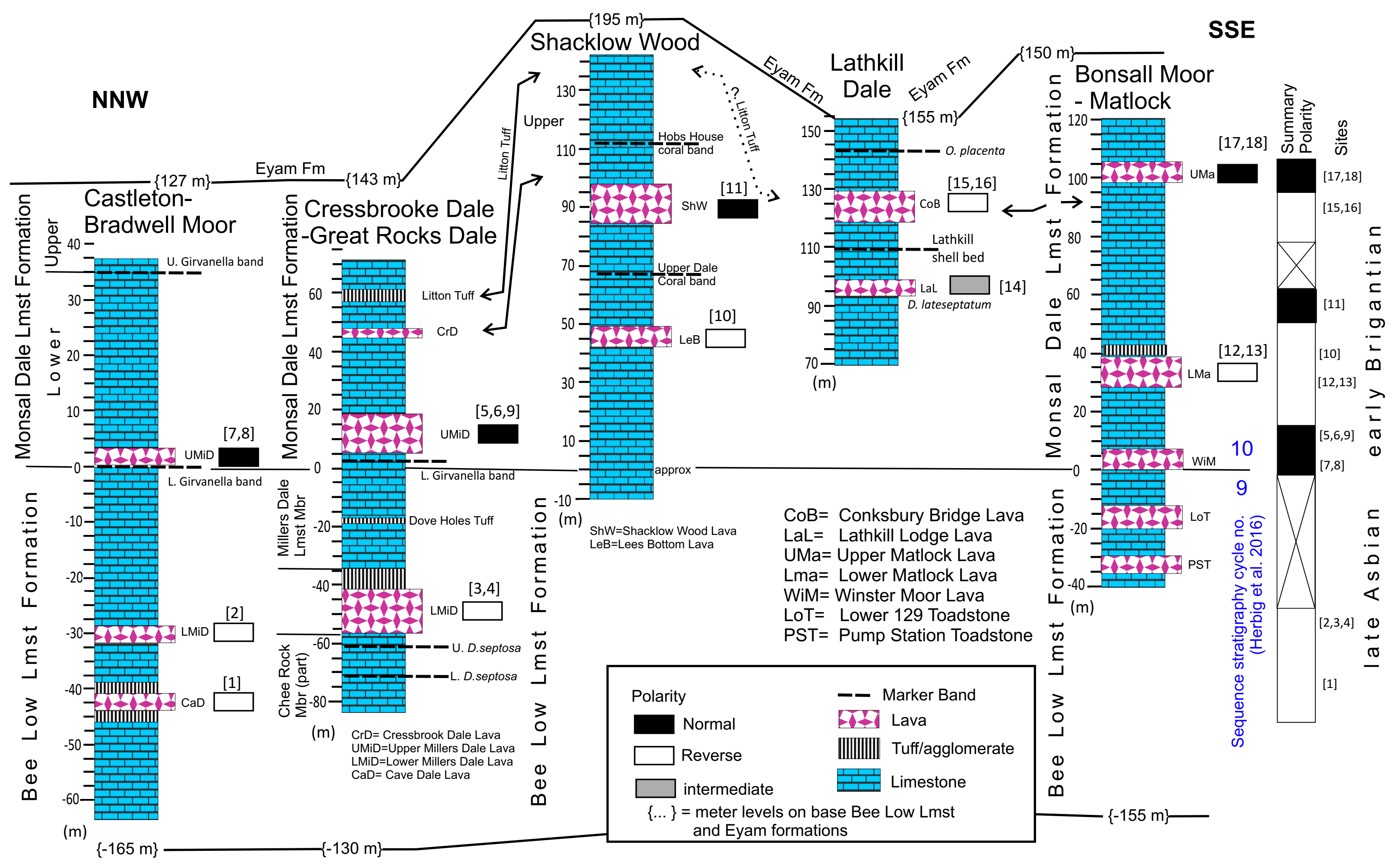




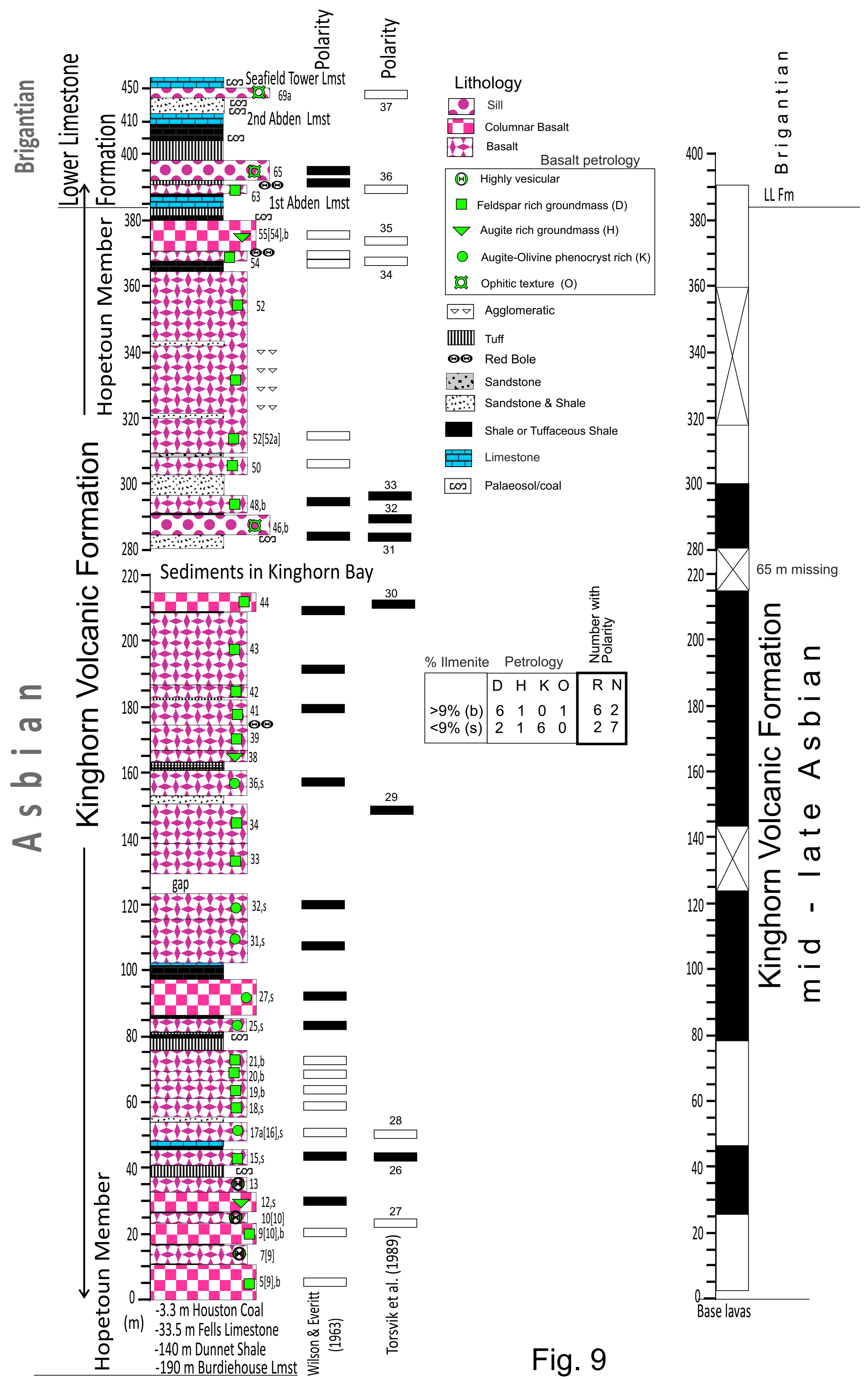




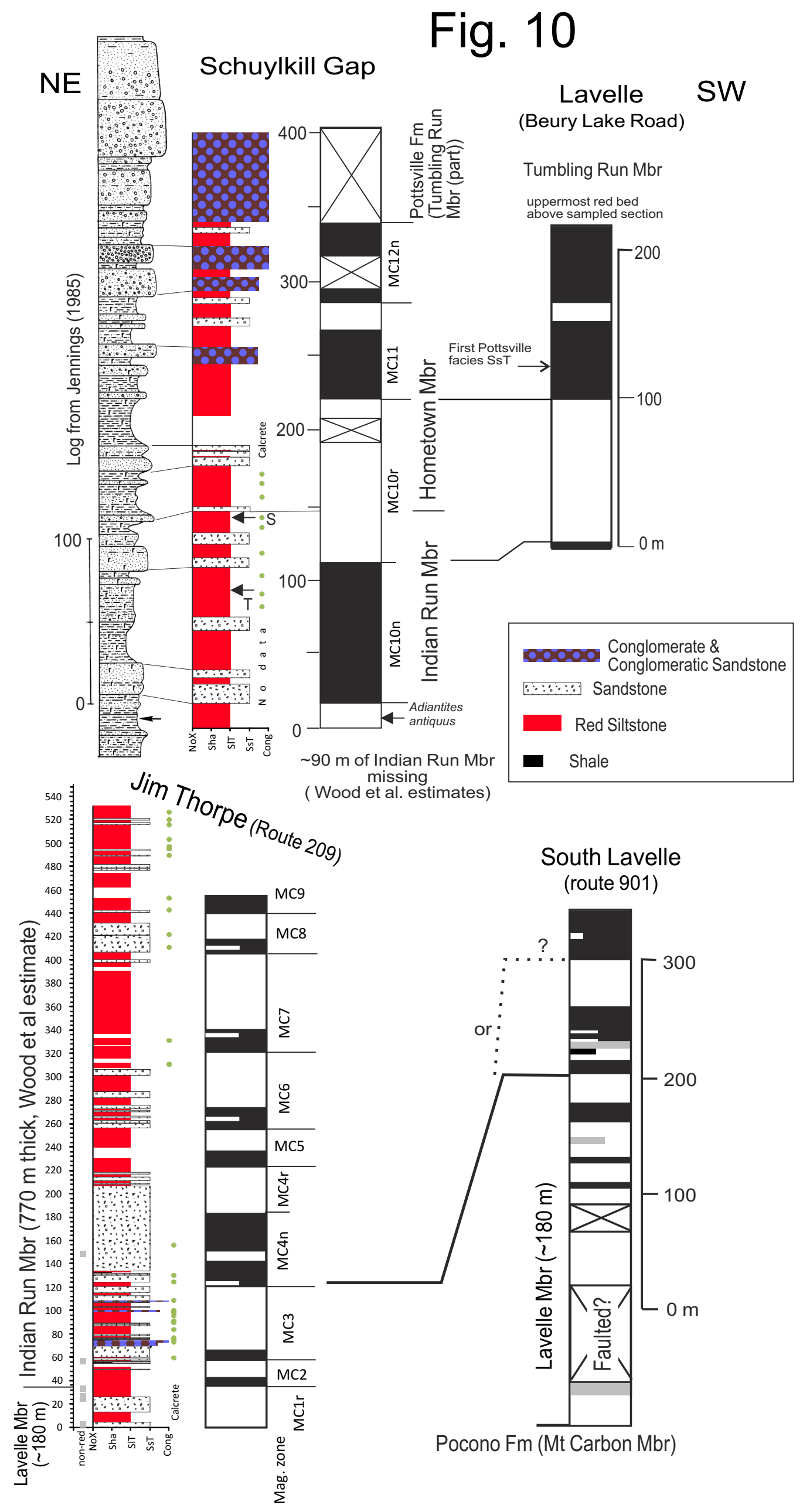


Fig. 11

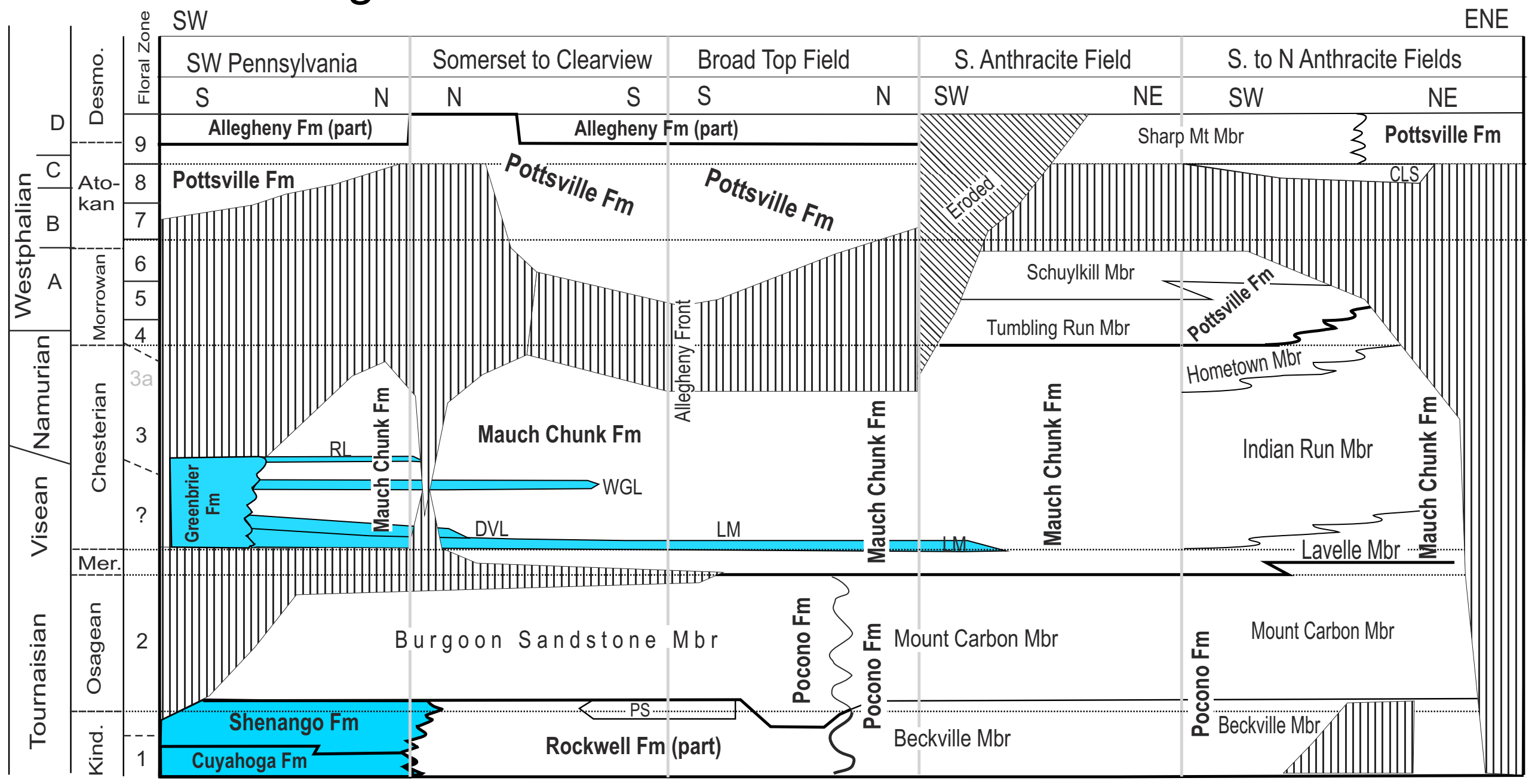



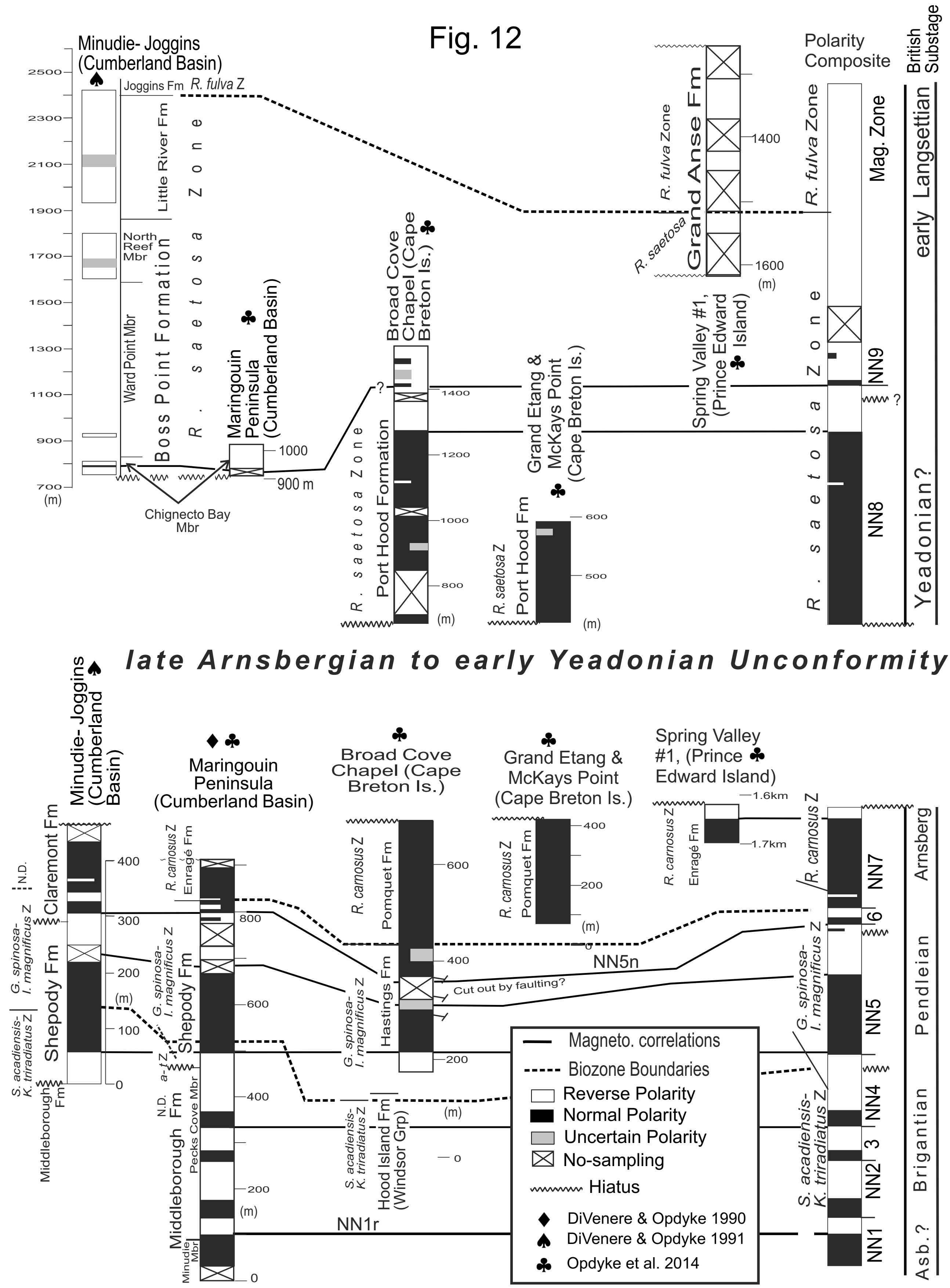
Fig. 13

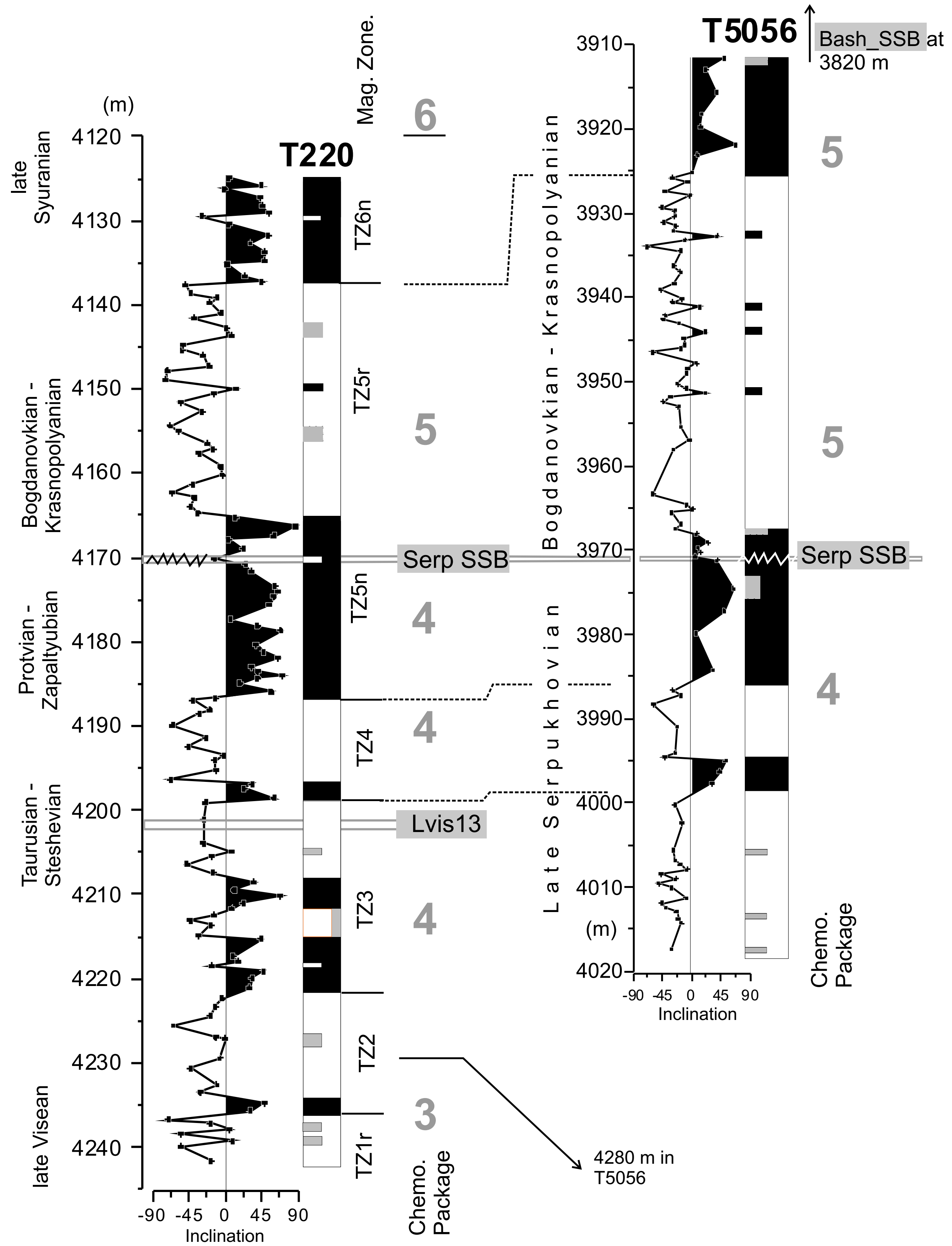


Fig. 14

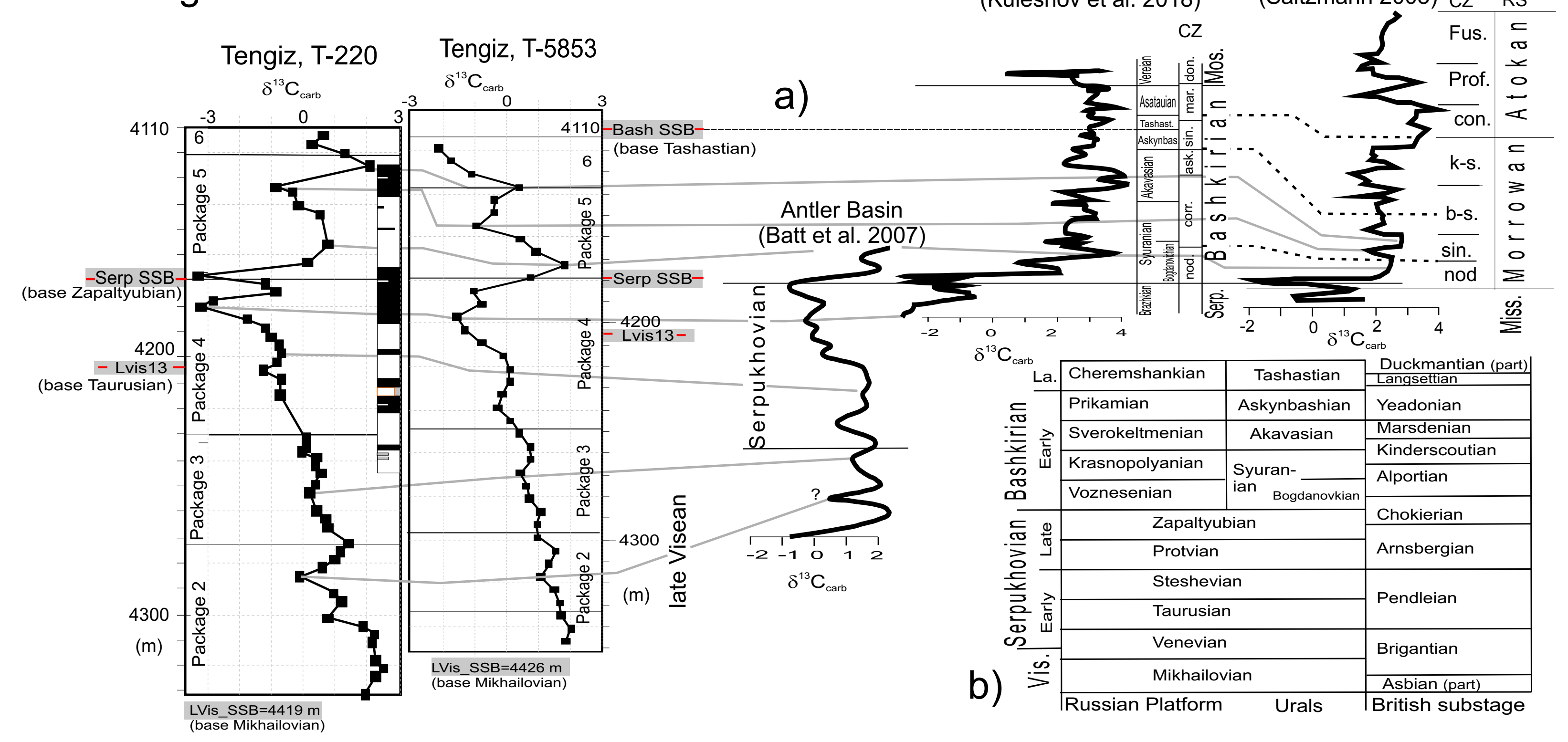




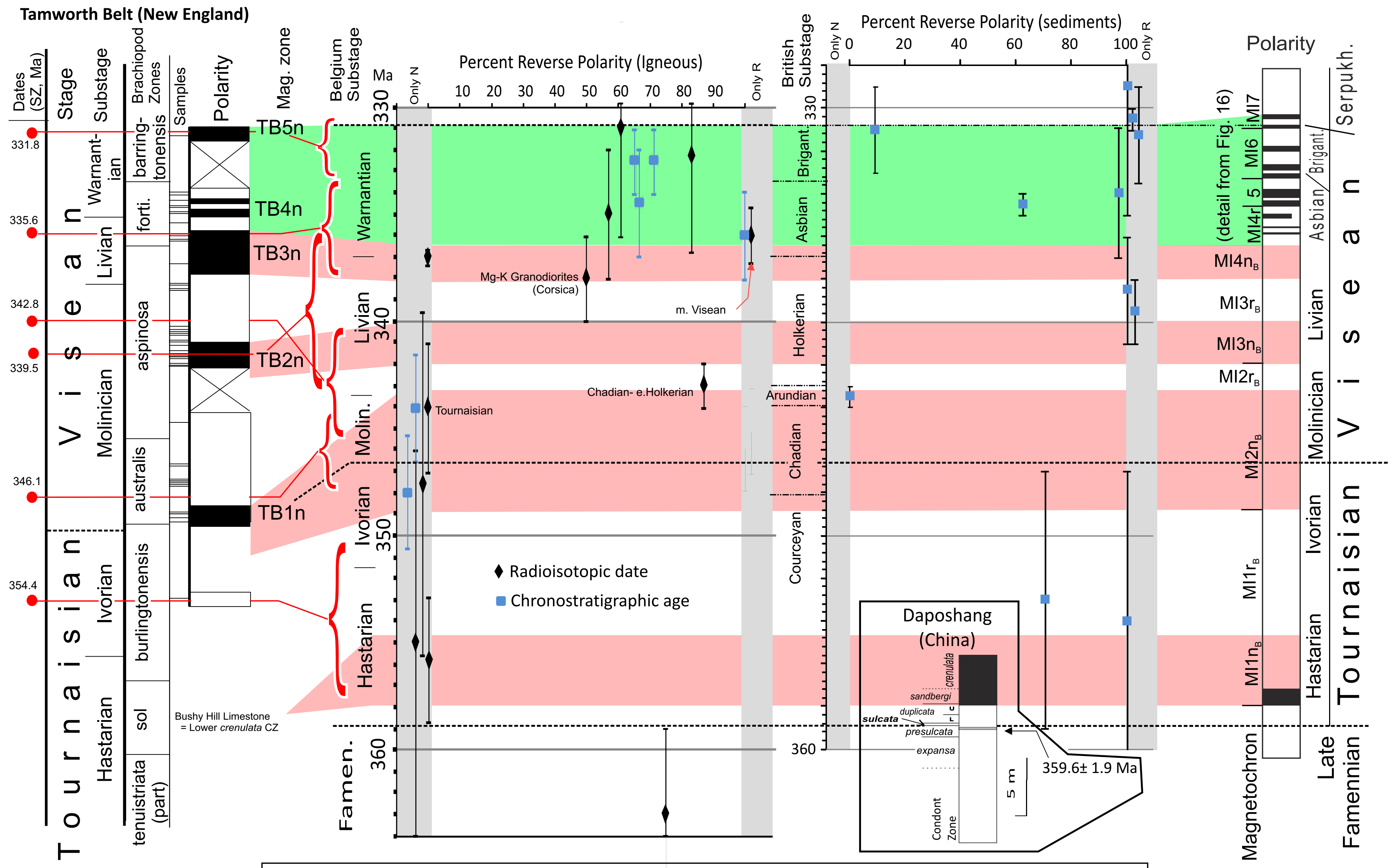

Normal Polarity $\square$ Normal Polarity Bias $\square \begin{aligned} & \text { Reverse Polarity \& } \\ & \text { Reverse Bias }\end{aligned} \quad \square$ Mixed polarity interval

Fig. 15 


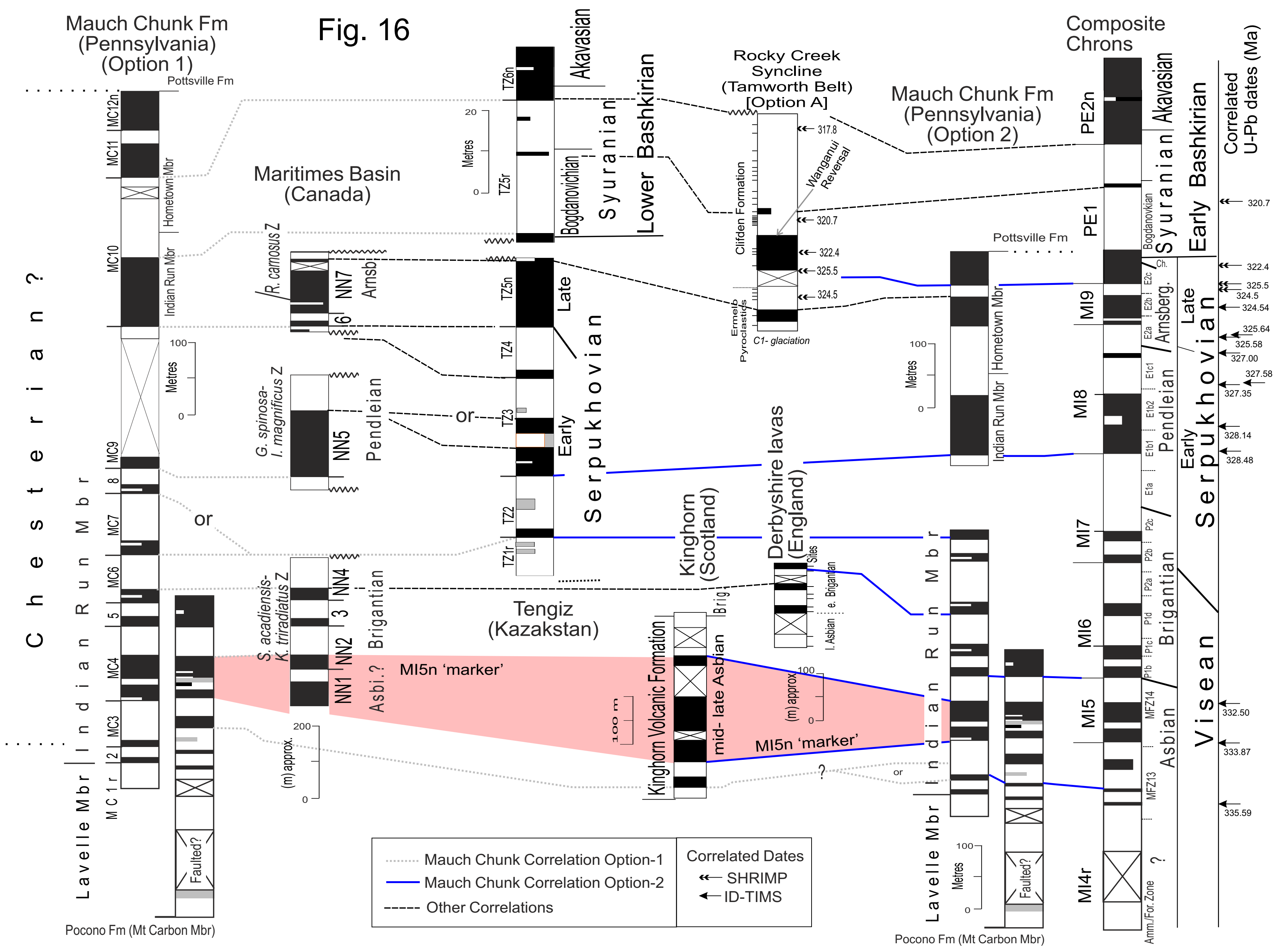




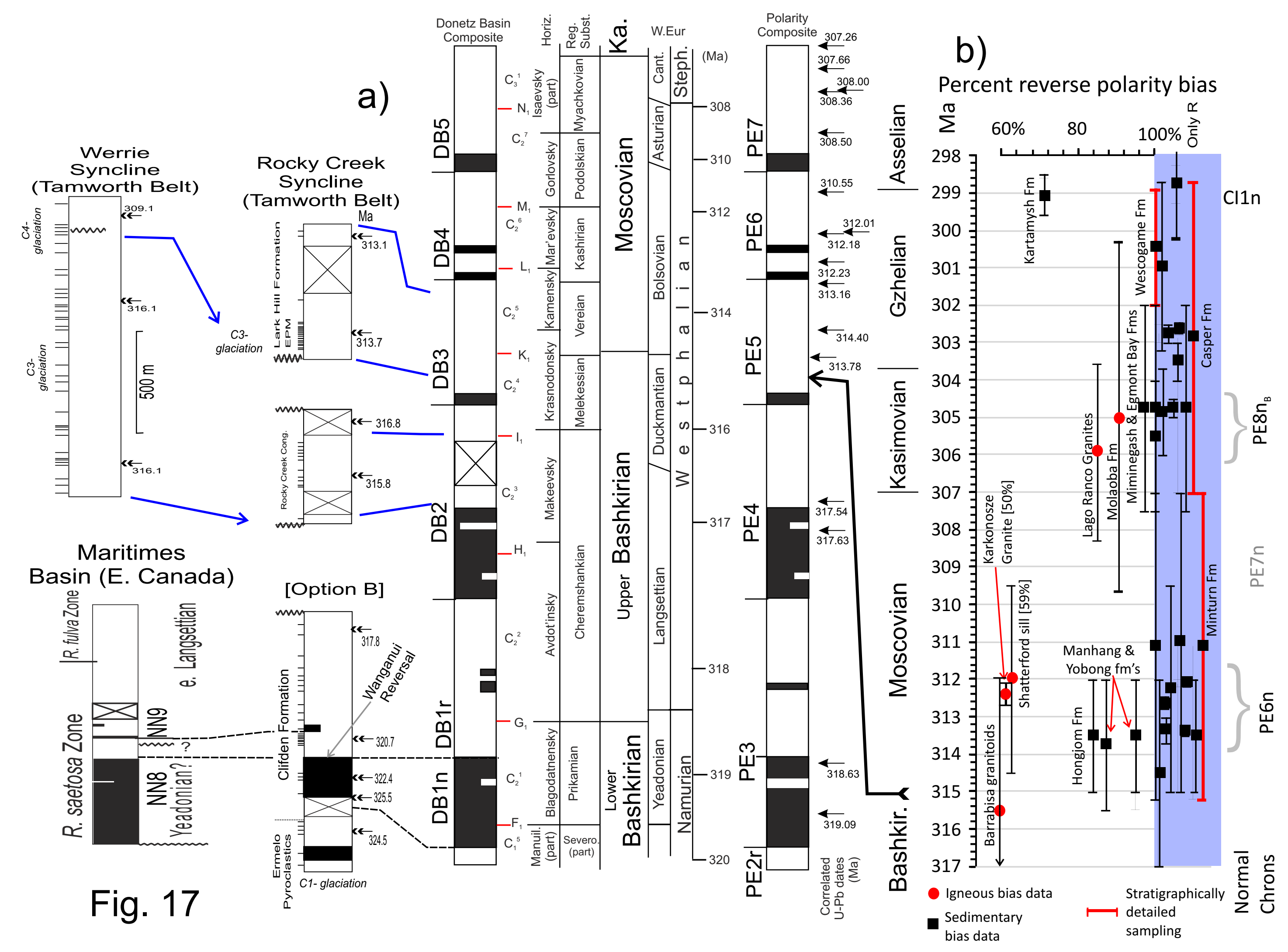


Fig. 18
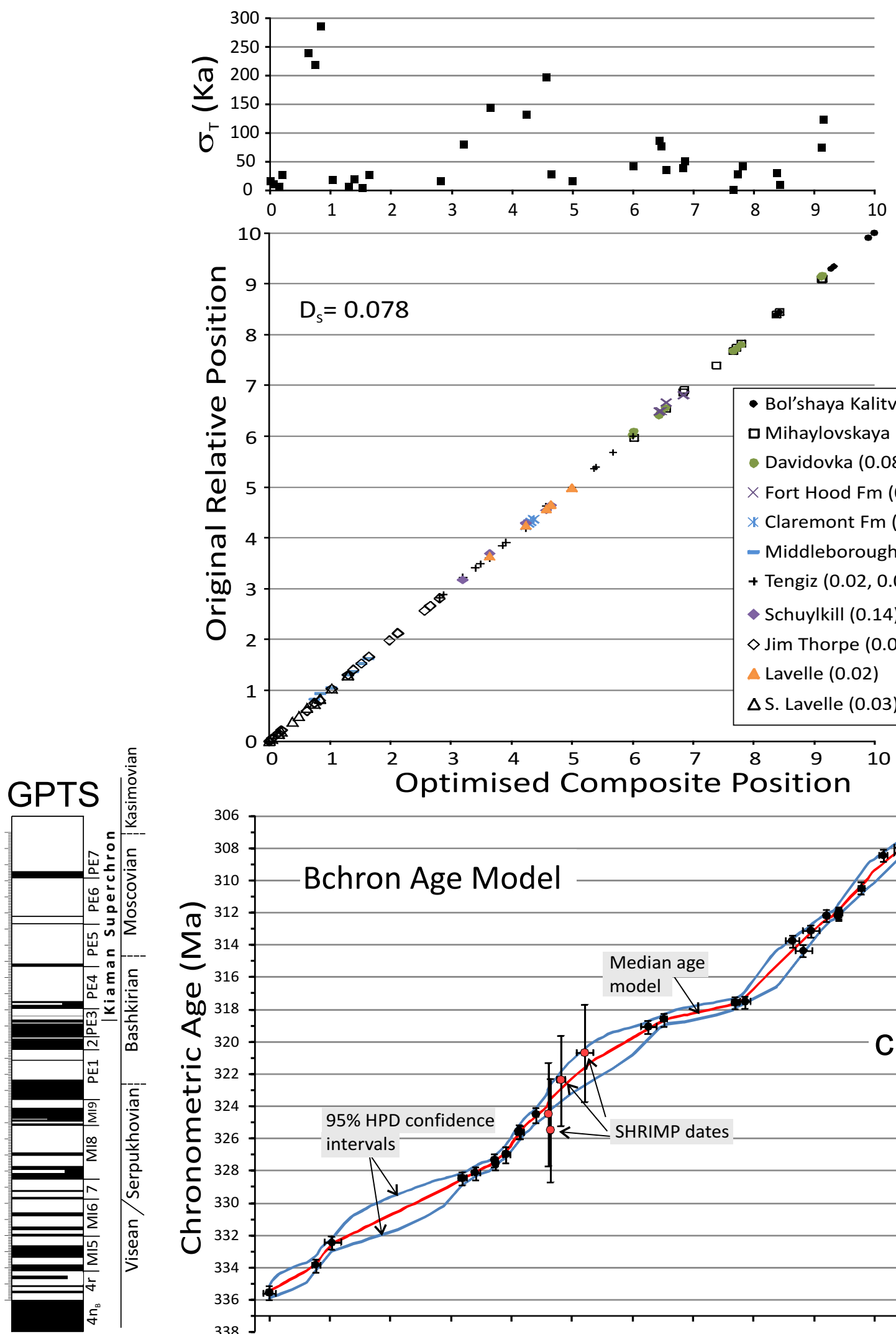

a)
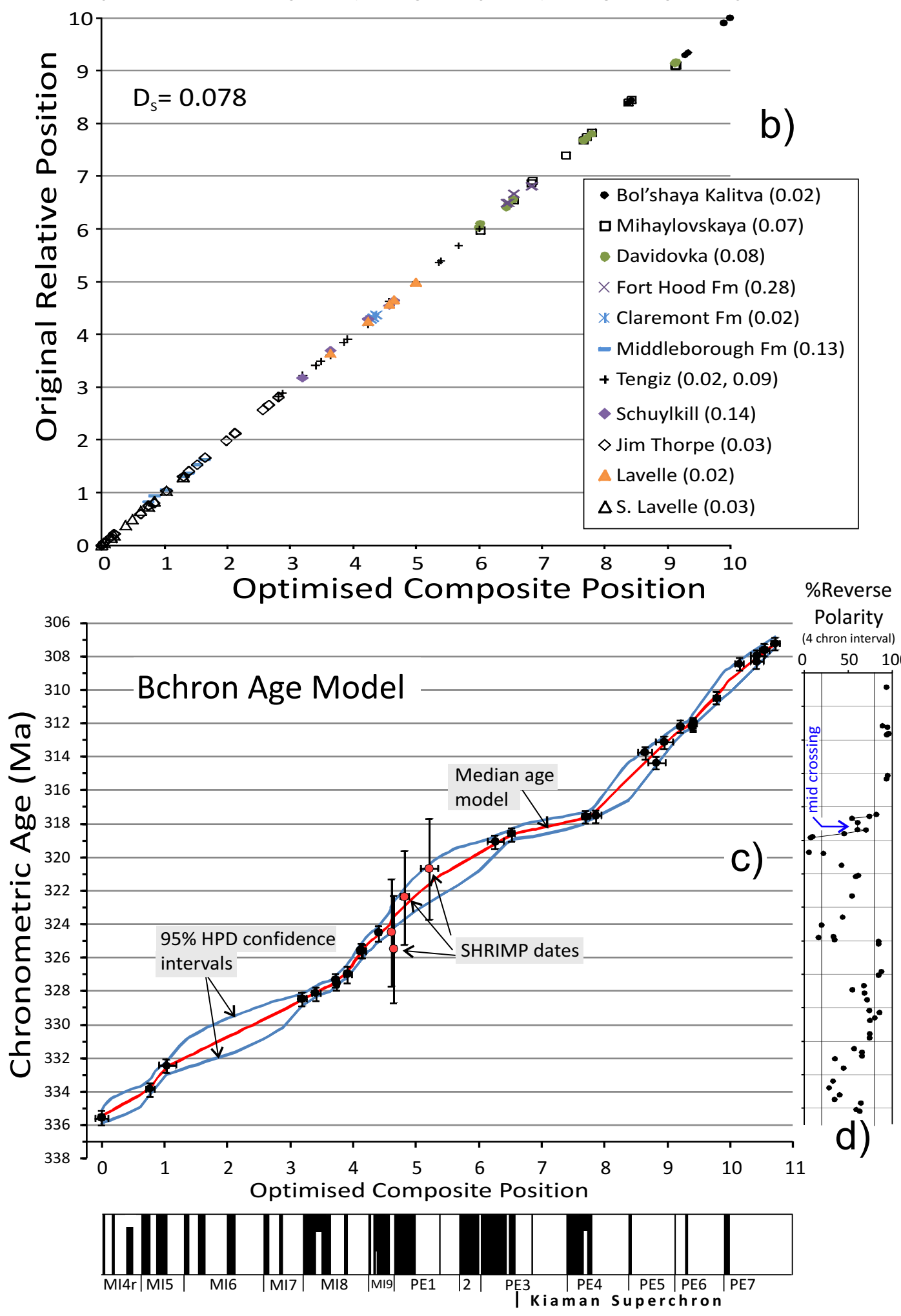

Polarity

(4 chron interval) $0 \quad 50 \quad 100$ 


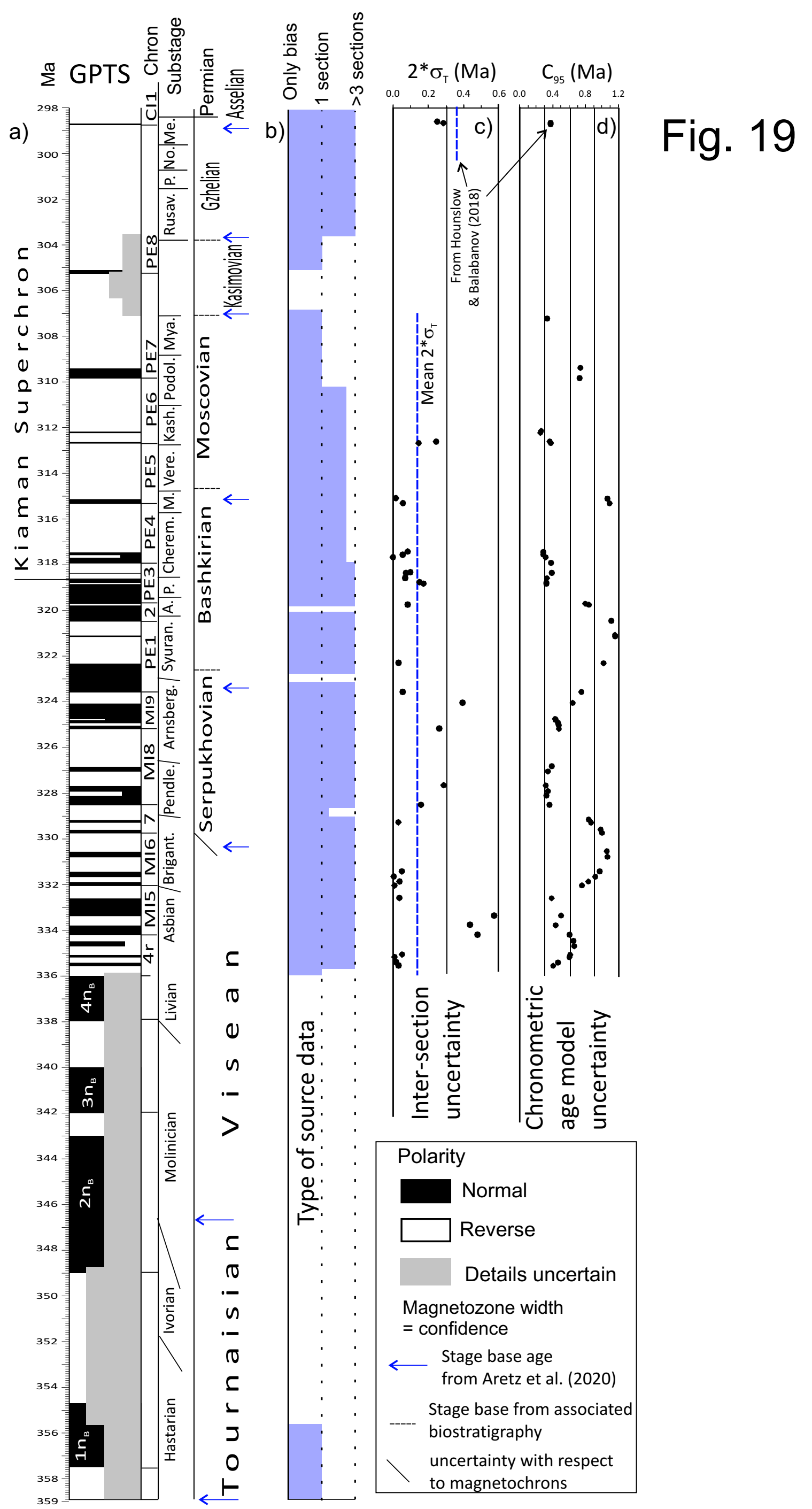

